\title{
Some Silicified Strophomenacean Brachiopods from the Ordovician of Kentucky, with Comments on the Genus Pionomena
}

GEOLOGICAL SURVEY PROFESSIONAL PAPER 1066-L

Prepared in cooperation with the

Commonwealth of Kentucky,

University of Kentucky,

Kentucky Geological Survey

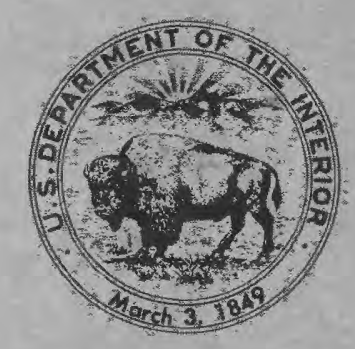





\section{Some Silicified Strophomenacean Brachiopods from the Ordovician of Kentucky, with Comments on the Genus Pionomena}

By JOHN K. POPE

CONTRIBUTIONS TO THE ORDOVICIAN PALEONTOLOGY OF KENTUCKY AND NEARBY STATES

Edited by JOHN POJETA, JR.

GEOLOG ICAL SURVEY PROAESSIONALAAPER 1066-L

Prepared in cooperation with the Commonwealth of Kentucky, University of Kentucky, Kentucky Geological Survey

Descriptions and illustrations of eight species of stropbomenoid brachiopods; Leptaena kentuckiana is described as a new species. Pionomena is sbown to be an early davidsoniacean bracbiopod.

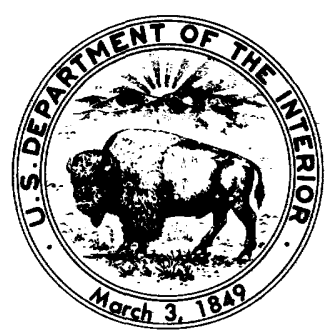




\section{UNITED STATES DEPARTMENT OF THE INTERIOR}

JAMES G. WATT, Secretary

\section{GEOLOGICAL SURVEY}

Dallas L. Peck, Director

\section{Library of Congress Cataloging in Publication Data}

Pope, John K.

Some silicified strophomenacean brachiopods from the Ordovician of Kentucky, with comments on the genus Pionomena.

(Contributions to the Ordovician paleontology of Kentucky and nearby states) (Geological Survey professional paper ; 1066-L) Bibliography: $p$.

Supt. of Docs. no.: I 19.16:1066-L

1. Strophomenida. 2. Pionomena. 3. Paleontology-Ordovician. 4. Paleontology-Kentucky. I. Pojeta, John. II. Title. III. Series. IV. Series: Geological Survey professional paper ; 1066-L. QE797.S89P66 $564^{\prime} .8 \quad 82-600114$

For sale by the Distribution Branch, U.S. Geological Survey, 604 South Pickett Street, Alexandria, VA 22304 


\section{CONTENTS}

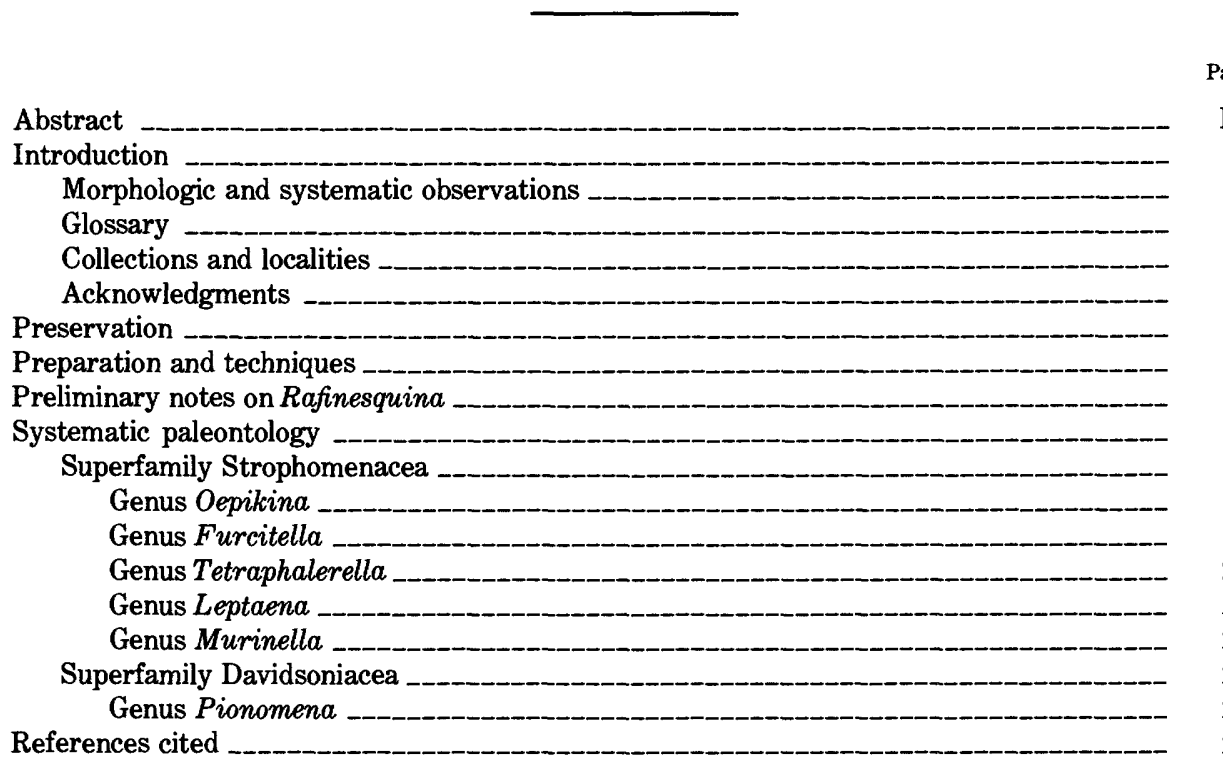

\section{ILLUSTRATIONS}

Plates 1-3. Oepikina.

4. Tetraphalerella.

5. Furcitella and Murinella?

6. Tetraphalerella and Furcitella.

7. Tetraphalerella, Holtedahlina, Coolinia, and Pionomena.

8. Leptaena.

FiguRES 1-6. Scattergrams of:

1. Length vs. width, and histograms, for Oepikina minnesotensis from USGS loc. $5078-\mathrm{CO}$

2. Length vs. height, and histogram of height, for ventral valves of Oepikina minnesotensis from USGS loc. 5078-CO

3. $45^{\circ}$ diagonal measurement vs. width, and histogram of $45^{\circ}$ diagonal measurement, for Oepikina minnesotensis from USGS loc. 5078-CO

4. Length vs. width, and histograms, for Oepikina minnesotensis from USGS loc. 7875-CO

5. Length vs. height, and histogram of height, for ventral valves of Oepikina minnesotensis from USGS loc. 7875-CO

6. $45^{\circ}$ diagonal measurement vs. width, and histogram of $45^{\circ}$ diagonal measurement, for Oepikina minnesotensis from USGS loc. $7875-\mathrm{CO}$

7-9. Combined scattergram fields of:

7. Length vs. width for Oepikina minnesotensis from USGS locs. 5078-CO and 7875-CO

8. Length vs. height for Oepikina minnesotensis from USGS locs. 5078- $\mathrm{CO}$ and 7875-CO

9. $45^{\circ}$ diagonal measurement vs. width for Oepikina minnesotensis from USGS locs. 5078-CO and 7875-CO

10. Summary of statistics for Oepikina minnesotensis from USGS locs. 5078-CO and $7875-\mathrm{CO}$ 
11. Comparison of combined scattergram fields of length vs. width for Oepikina minnesotensis from Kentucky and from the northern Mississippi Valley region and comparison of scattergram fields of length vs. width for $O$. minnesotensis from Kentucky with published length and width measurements of other species of Oepikina

12. Scattergram of the length vs. maximum width of dorsal valves of Pionomena recens Neuman

Page

\section{TABLE}

TABLE

1. Localities from which silicified specimens of Oepikina minnesotensis were recovered in Kentucky

\section{SYSTEM OF MEASUREMENT UNITS}

The investigations underlying this series of reports were made over a period of years, and distances and stratigraphic measurements appear fairly uniformly in English units. Measurements of fossil specimens, on the other hand, follow the long-standing convention of appearing in metric units. Because of the dates of the investigations and the amount of resulting data, the English measurements have been retained. Conversions to metric units may be made by using the following conversion table:

To convert English unit:

Mile (mi)

Foot (ft)

Inch (in)
To metric unit:

Kilometer (km)

Meter (m)

Centimeter $(\mathrm{cm})$
Multiply by:

1.61

.305

.394 


\title{
SOME SILICIFIED STROPHOMENAGEAN BRACHIOPODS FROM THE ORDOVICIAN OF KENTUGKY, WITH COMMENTS ON THE GENUS PIONOMENA
}

\author{
By JOHN K. POPE
}

\begin{abstract}
Eight species of silicified strophomenid brachiopods from Ordovician rocks of Kentucky are described in this report. Seven species are strophomenaceans, including six from the Middle Ordovician and one, Leptaena kentuckiana n. sp., from the Upper Ordovician. Pionomena recens Neuman from the Middle Ordovician is referred to the Davidsoniacea. Three of these species also occur in the Middle Ordovician of the northern Mississippi Valley region. Rafinesquina is abundant at many localities throughout the Middle Ordovician section of Kentucky. Other silicified strophomenaceans are rare and have been recovered only from the lower part of the Middle Ordovician section of the area.

Oepikinia minnesotensis has a high degree of polymorphism of outline shape, profile, and ornament. Some Middle Ordovician species heretofore placed in Strophomena are reassigned to Tetraphalerella. Furcitella and Holtedahlina are differentiated only by the presence of a prominent fold in adult valves of Holtedahlina because a bifid dorsal medial ridge occurs in species of both genera and because the transmuscle ridges of both genera are similar. The possession by Pionomena recens of a perideltidium, dentifers, dorsal medial node, and impunctate shell indicates relationship of this genus to the Davidsoniacea.
\end{abstract}

\section{INTRODUCTION}

Eight species of strophomenid brachiopods are described in this report. Seven species are strophomenaceans, including six from the Middle Ordovician and one, Leptaena kentuckiana n. sp., from the Upper Ordovician. Pionomena recens from the Middle Ordovician is referred to the Davidsoniacea. The silicified strophomenacean brachiopods from the Middle Ordovician of Kentucky, except for Rafinesquina, show remarkably low species diversity and occur at few localities in generally small numbers of individuals. Indeed, only 12 collections of silicified fossils from the Middle Ordovician rocks of Kentucky contain identifiable

\footnotetext{
'Miami University, Oxford, Ohio 45056.
}

strophomenaceans other than Rafinesquina, whereas more than 120 collections contain specimens of Rafinesquina. The paucity of strophomenaceans other than Rafinesquina contrasts sharply with the abundance and diversity of these brachiopods in the Upper Ordovician rocks of the region. Rafinesquina is so abundant and widespread in the Middle Ordovician rocks of Kentucky that this genus is not dealt with in this report and is under continuing investigation.

Only the High Bridge Group and the lower stratigraphic units of the Lexington Limestone contain silicified strophomenaceans other than Rafinesquina. Although environmental factors during deposition of the upper members of the Lexington Limestone and Clays Ferry Formation might have suppressed less opportunistic species of this superfamily, it seems more likely that the collections are not extensive enough to reveal all potential taxa. Two expected well-known strophomenacean species from the Middle Ordovician of Kentucky, Strophomena vicina Foerste and Tetraphalerella auburnensis nasuta (Cooper) [=Strophomena incurvata of authors], are not represented in the collections.

Species identification has been intentionally conservative so as to enhance the potential usefulness of these few strophomenaceans for time correlation and determination of the provincial affinities of the total fauna. Although such a small number of species precludes any definitive determination of age or provincial affinity, the mutual occurrence of three species, Oepikina minnesotensis, Tetraphalerella musculosa, and Furcitella scofieldi, in Kentucky and in the northern Mississippi Valley region may be significant. Additionally, distinction of species has been conservative because the writer 
is convinced that many strophomenacean genera have been excessively subdivided at the species level on inadequate morphological criteria. For this region, several identifications are tentative, and two unique dorsal valves are referred simply to Tetraphalerella $\mathrm{sp}$. and Murinella? sp. The new species, Leptaena kentuckiana, is based on a few specimens and eventually may be shown to be a variant of a previously named species; however, on the basis of the present evidence, it is morphologically distinct and is named herein.

\section{MORPHOLOGIC AND SYSTEMATIC OBSERVATIONS}

The high degree of polymorphism documented by Bretsky and Bretsky (1975) in Oepikina minnesotensis (Winchell) from the northern Mississippi Valley region is manifest within populations of this species from Kentucky. In particular, O. minnesotensis shows variability in outline shape, profile, and details of ornament, which are judged to be inconclusive differentia of species of Oepikina. Future studies of large populations of Oepikina may indicate some synonymy among presently recognized species. The teeth of 0 . minnesotensis are wide and bear distinctive transverse grooves. Semidenticles on the dorsal surfaces of the teeth are oriented perpendicular to the hingeline (pl. 2, fig. 1d) and thus resemble the true denticles of the early stropheodontids, for example, Eostropheodonta.

Provided the type species of Strophomena is accepted as $S$. planumbona (Hall), Tetraphalerella proves to be stratigraphically longer ranging and systematically more diversified than heretofore recognized. Although these genera are superficially homeomorphic, Tetraphalerella is distinguished from Strophomena by the possession of coarse pseudopuncta, very slender teeth, an inclined diductor-muscle bounding ridge, and the absence of prominent trans-muscle ridges. Many of the Middle Ordovician species presently assigned to Strophomena that have been studied for this report actually belong to Tetraphalerella, for example, Strophomena auburnensis Fenton, $S$. basilica Cooper, $S$. costellata Cooper, S. musculosa Fenton, and S. plattinensis Fenton. All the specimens assigned to $S$. "incurvata" (Shepard) (see discussion in Cooper, 1956, p. 938-939) that have been examined belong to Tetraphalerella. Species of Strophomena s.s. do occur in the Middle Ordovician, for example, Strophomena vicina Foerste, so that these genera cannot be identified on the basis of stratigraphic age.

Furcitella and Holtedahlina are most clearly separated by the presence of a prominent fold in adult valves of Holtedahlina. Heretofore, Furcitella has been distinguished principally by bifurcation of the medial ridge of the dorsal valve, but this character also occurs in immature specimens of $H$. sulcata (de Verneuil), type species of Holtedahlina. The bifid ends of the medial ridge of adult specimens of $H$. sulcata are enlarged to form a pair of rounded lobes (pl. 7, figs. 11-12). The dorsal trans-muscle ridges of $H$. sulcata (pl. 7, fig. 12) are more pronounced than those of Furcitella; the absence of well-defined trans-muscle ridges in the specimen of $H$. sulcata illustrated by Cooper (1956, pl. 229, B, fig. 8; repeated by Williams, 1965 , p. H386, fig. $247-1 b$ ) is anomalous.

Pionomena is assigned to the Davidsoniacea because of the presence of a perideltidial area, an orthotetid-type socket structure (dentifers), dorsal medial node, and apparently impunctate shell structure. Pionomena is assigned provisionally to the family Fardeniidae but differs from Fardenia by having the socket suspended above the floor of the valve, as has Gacella (see Williams, 1962, p. 222), rather than excavated into the shell material.

\section{GLOSSARY}

The general morphology of strophomenacean brachiopods is well known (Pope, 1976) and is not reviewed herein. With few exceptions, standard morphological terms have been used. Radial ornament has not been described on all specimens by conventional designations such as ramicostellate, parvicostellate, etc., because of inconsistency in the patterns of increase of costellae of the species described. Crenulations of the hinge teeth of strophomenaceans s.s. are called "semidenticles" after the usage of Spjeldnaes (1957, p. 20 ). Specimens in a recently discovered population of Eostropheodonta sp. from Maysvillian rocks of Ohio possess both semidenticles and denticles, indicating that these structures are not homologues, contrary to Spjeldnaes (1957, p. 22). The semidenticles of Oepikina minnesotensis (pl. 2, fig. 1d) have the position and orientation of the denticles of Eostropheodonta but the size and disorganization of the semidenticles of a strophomenacean. These features are called semidenticles only by convention. The term "socket buttress ridge" (pl. 3 , figs. $9 b, 13 b, 16 b ; \mathrm{pl} .5$, fig. $1 c$ ) is retained here as a substitute for "socket ridge" in an attempt to avoid implication of homology of this structure in strophomenaceans to structures of similar function in other groups of brachiopods. The posterio-lateral socket ridge lies between the socket and the interarea (pl. 3, figs. $9 b, 13 b, 16 b$ ). The posterio-lateral socket ridges are accommodated by grooves in the hinge teeth of concavoconvex species or by pockets between the hinge teeth and the interarea of resupinate species. The posteriolateral socket ridge has the same function as the outer socket ridge of rostrate brachiopods. The dorsal trans- 
muscle ridges (or septa, depending on height) (pl. 3, fig. $9 a$; pl. 5, fig. $1 d ;$ pl. 7, fig. 11) are designated as follows: the broad, generally short ridge extending toward the anterior from the notothyrial platform is called the medial ridge: the narrow, sharply defined breviseptum extends anterad from the end of the medial ridge; the pair of anterio-medial ridges lies on either side of the medial ridge and breviseptum; the posterio-lateral ridges are lateral to the anterio-medial ridges. Adventitious ridges or septa (see Pope, 1976, p. 138, fig. 1) may be intercalated between the principal trans-muscle ridges. The suspended socket structure of Pionomena and other davidsoniaceans is called the dentifer (pl. 7, fig. 16) following the usage of Cooper and Grant (1974, p. 258-259). The term "medial node" (pl. 7, figs. 14-15, $24,28-31$ ) is applied to the small bead, rod, or spine on the notothyrial platform between the bases of the cardinal process lobes of some davidsoniaceans.

\section{COLLECTIONS AND LOCALITIES}

The silicified strophomenids described herein come from collections assembled by the U.S. Geological Survey. These collections have been assigned locality numbers listed in the Cambrian-Ordovician catalog (CO). All U.S. Geological Survey locality and collection numbers referred to herein, except 5078-CO, are documented in parts A (Pojeta, 1979) or K (Parsley, 1981) of this series. Collection 5078-CO is from the same locality, has the same coordinates and section name, and comes from the same quadrangle as collection 7875-CO (Pojeta, 1979); it is from the Camp Nelson Limestone, 28 $\mathrm{ft}$. above the base of the section. Most specimens figured and discussed have been assigned numbers from USNM 245277 to 245370 in the U.S. National Museum of Natural History catalog. The few illustrated specimens that bear "MU" numbers are in the collection of the Department of Geology of Miami University, Oxford, Ohio.

\section{ACKNOWLEDGMENTS}

John Pojeta, Jr., U.S. Geological Survey, generously made available the collections studied for this report. F. J. Collier lent specimens of Pionomena from the U.S. National Museum of Natural History, Washington, D.C. The extensive collection of Ordovician brachiopods at Miami University, Oxford, Ohio, assembled by the late W. H. Shideler, from Minnesota, Wisconsin, Kentucky, and Oklahoma, provided comparative specimens for this study. Ronald F. Spraitzar and Brian K. Murphy assisted respectively with scanning-electron-microscope (SEM) observation and photography of Pionomena recens and with drafting of graphs. The SEM was made available by Thomas K. Wilson of the Department of Botany of Miami University. Kenneth G. Wilson, Department of Botany, Miami University, reviewed the graphs of Oepikina minnesotensis. The late Frances T. Keyler provided some of the instrumentation for this work.

\section{PRESERVATION}

All the brachiopods from Kentucky described in this report are silicified. Considerable variation in the quality of preservation seems to be related largely to the mode of replacement. The replicating mineral is assumed to be quartz, including its cryptocrystalline varieties, although this identification has not been established definitely by X-ray diffraction. The replacing mineral will generally be called "silica" because of lack of precise mineralogical identification. Other minerals, particularly fluorite, pyrite, and goethite, have been observed to replace small parts of a few shells.

Three distinct modes of silicification of shells are represented. These varieties of silicification do not seem to be taxonomically selective, so I assume that the types of silicification are related to factors generally present throughout the rocks of a locality and not to factors of the microstructure, porosity, or composition of the original shells. No substantial evidence has been found that indicates the time or environment of silicification.

By far the most common mode of silicification is replacement of the external and internal surfaces of valves by thin zones of cryptocrystalline silica (pl. 3, fig. 9 ; pl. 4, figs. 1, 5). This material is so fine grained and brittle that is resembles eggshell or fine bone china. It is generally white to light gray, and it breaks sharply and smoothly without crumbling.

Single valves preserved by this surface silicification are generally hollow and crush quite readily. Bridges or columns of coarser quartz crystals may extend between the internal and external surface-replacement layers. Exceptionally, as in the case of some specimens of Rafinesquina from the upper members of the Lexington Limestone, valves are totally replaced by this finegrained silica.

It seems likely that this type of replication was regulated simply by the depth to which silica-bearing ground water could penetrate into the shell, as if the silicification itself formed an impermeable armor. This type of replacement does not seem to be related to the calcitic microstructure or composition of the original shell because the original inner and outer surface layers of different species probably would not have had identical microstructures and compositions. Internal surfaces and dorsal valves subjectively seem to be better preserved by this material than their counterparts.

This mode of replacement, although preserving most of the fine detail of the surfaces of valves, is morphologically selective. Cardinal-process lobes are generally hollow (pl. 3, fig. 13b; pl. 5, fig. 1c) and have 
conspicuous holes where the myophore areas should be. Teeth are hollow and are commonly missing (pl. 6, fig. 6). The pseudodeltidium commonly is absent. Where present, the external dome of the pseudodeltidium seems to be constructed of coarse-grained silica. The beak of the ventral valve may contain a hole where the "root" of the pseudodeltidium was inserted between the external shell matter and the secondary shell material deposited within the delthyrial chamber (pl. 2, fig. 4b). Rather commonly, small areas of valves preserved by surface silicification show the concentric welts characteristic of beekite replacement (pl. 5, fig. 1a).

Preservation by saccharoidal silica (pl. 4, fig. 6; pl. 7, figs. 1-9) is relatively common. Shells preserved in this manner tend to be quite porous and fragile because the grains are weakly cemented together. Normally, the saccharoidal structure is continuous throughout the thickness of a single valve. Saccharoidal replacement has not been selective of particular sites, shell layers, or morphological structures within the valves. Structures such as teeth, cardinal-process lobes and the margins of valves commonly are absent because of abrasion or percussion of this fragile material. Fine surface details such as costellae and growth lines are absent or poorly preserved by the saccharoidal silica. Some specimens show sparkling overgrowths of fine quartz crystals that impart an arenaceous surface texture (pl. 7, fig. 5). Areas of shells otherwise preserved by saccharoidal silica may show the concentric welts characteristic of beekite (pl. 7, fig. 2).

Total replacement of shells by beekite (pl. 2 , fig. 6 ; pl. 3 , figs. 1-3; pl. 5, fig. 4), that is, chalcedony, is relatively uncommon. Such shells are generally strong and resistant to abrasion. Most specimens preserved by this material are white to light gray, although some show the blue color of chalcedony. Specimens preserved by beekite lack fine surface detail so that features such as costae, growth lines, and markings of the muscle scars cannot be observed adequately (pl. 5, fig. 7). Larger structures such as cardinal-process lobes, teeth, and muscle bounding ridges tend to be distorted. Preservation by beekite involves the entire shell; that is, such preservation is not restricted to certain morphological structures or shell layers. A few chalcedony steinkerns are present in the collections; none are figured. Their lack of surface detail makes identification quite uncertain.

On small areas of some valves of Oepikina and Rafinesquina is a very thin, white to light-gray coating of flexible, presumably organic, material. These coatings have the physical characteristics of thin paper and seem to be constructed from a felt of fine fibers. This material normally adheres very tightly and is unnoticed until an attempt is made to clean the shells for photography. Fibers and debris may be attached to these papery sheets, which are lifted as the foreign matter is removed. This material seems to be attached most often to the internal surfaces of valves, perhaps because it peels more readily from the smoother internal surfaces. The origin of this papery material is unknown, but the material may be modern because of its light color, that is, lack of carbonization. It may be an organic residue liberated from the limestone by the etching bath and not flushed from the surface of the specimens. It is probably not organic matter originally incorporated in the brachiopod shells and excluded during silicification, nor is it likely to be an altered remnant of brachiopod soft tissue.

\section{PREPARATION AND TECHNIQUES}

The silicified strophomenacean brachiopods were prepared in the Washington laboratory of the U.S. Geological Survey by the process outlined by Neuman (1967, p. A2) and Pojeta (1979). Most of the specimens were liberated by digestion of the limestone in commercial-grade hydrochloric acid diluted 10 parts water to 1 part acid. Small samples from many localities were separately digested in diluted glacial acetic acid to recover phosphatic fossils and also to determine whether etching in acetic acid would produce specimens superior to those processed in hydrochloric acid. The silicified fossil residues that had been processed in acetic acid were dyed pink for identification.

Comparison of strophomenacean specimens from the same localities processed in these different acids reveals that no apparent advantage is gained by digestion in acetic acid. If anything, the specimens prepared in hydrochloric acid have less clinging mud and sand-sized particles than those processed in acetic acid. Whether this difference is related to more vigorous effervescence of the limestone digested in hydrochloric acid, to more thorough rinsing of the greater volume of residue processed in hydrochloric acid, or to the conspicuous dark pink of porous debris adhering to specimens processed in acetic acid cannot be determined. This difference is significant because these silicified specimens are so fragile that handling must be minimized, and secondary washing of specimens invariably leads to some breakage.

Most broken specimens have been repaired with polyvinyl resin (white) cement. This cement may be dissolved by prolonged soaking in warm water but generally is not softened by brief immersion of the specimens in water, as is necessary after photography. Specimens are mounted on heavy cardboard panels by means of acetone-soluble cement, and the panels are appropriately labeled. Specimens may be examined attached to the 
panels, thereby minimizing breakage, but the cement may be removed by use of acetone, without disturbing repairs made with the polyvinyl resin cement. Some small specimens, for example, the photographed specimens of Pionomena recens Neuman, were mounted on straight pins by means of acetone-soluble cement and were pinned to styrofoam sheets for storage.

Specimens have not been hardened, except inadvertently by saturation with the acetone-cementmounting solution. Experimental hardening of a few specimens resulted in a loss of crisp surface detail, which reduced their value for photography.

All specimens were coated with ammonium chloride for photography. Dying or staining the specimens to render them opaque proved unnecessary. Although many of the specimens are translucent, all were photographed above a nonreflective black-velvet background so that little if any light was transmitted up through the specimens to disturb the appearance of the surface.

These silicified specimens are too fragile to be measured by calipers. All length and width measurements were made from accurately calibrated photographs or from images of the specimens produced by an opaque projector set at a known magnification. Height measurements were made from photographs or by means of a very light pivoted rod in the form of a first-class lever accurately set to produce height magnification of a known amount.

These specimens are so fragile that all except those replaced by solid chalcedony must be manipulated only with thin flexible forceps. Mud and adhering sand were lightly brushed from specimens under water. Removal of lint presented a serious problem. Lint fibers cling tenaciously to the rough silica surfaces and also seem to be electrostatically attracted to some specimens. Lint fibers could be removed only by patient brushing and picking with forceps. Removal of lint by burning resulted in exfoliation and darkening of some specimens and should not be attempted. Because of the lint problem, these specimens should not be packaged in loose cotton, sawdust, or finely granular styrofoam. Sheet foam rubber seems to be the best packaging and storage medium. Attempts should not be made to remove masses of silicified matrix or fossil debris fused to specimens because this usually leads to fracture of the specimen.

\section{PRELIMINARY NOTES ON RAFINESQUINA}

The strophomenacean brachiopods in the silicified fossil residues from the Middle Ordovician of Kentucky are dominated by the genus Rafinesquina. More than
5,700 specimens belonging to this genus have been recovered from 121 localities. Time has not permitted numerical analysis of these specimens, which is essential in order to distinguish the subtly differing species of this genus. In addition, redescription of Middle Ordovician forms should await the conclusion of the revision of Late Ordovician species, which is nearing completion, by William Harmon of the University of Cincinnati.

The collections from Kentucky that have yielded Rafinesquina range stratigraphically from near the base of the Lexington Limestone in the Curdsville Limestone Member upward through the Clays Ferry Formation and into the Cincinnatian Provincial Series. Rafinesquina was not found in the High Bridge Group, below the Lexington Limestone, where its ecological position may have been occupied by Oepikina.

Forms resembling Rafinesquina trentonensis (Conrad) occur throughout the Lexington Limestone. In large collections from the Lexington Limestone, individuals show considerable variation of size, shape, and ornament. Biometric analysis is needed to determine whether the large specimens in these populations should be referred to $R$. trentonensis or to later species characterized by larger size and low convexity, such as $R$. winchesterensis filistriata Foerste, $R$. alternistriata (Hall), or R. fracta (Meek).

Some of the populations from the Grier Limestone and Tanglewood Limestone Members of the Lexington Limestone and from the overlying Clays Ferry Formation are dominated by specimens resembling $R$. winchesterensis filistriata. Specimens resembling $R$. winchesterensis winchesterensis Foerste are nowhere abundant in the silicified populations but appear as rare, exceptionally elongate forms in large collections of $R$. winchesterensis filistriata. Inexplicably, $R$. winchesterensis winchesterensis is relatively common in collections of calcareous specimens from the Millersburg Member of the Lexington Limestone. Large specimens with coarse, strongly differentiated costellae, tentatively referred to $R$. alternistriata, are not abundant and generally do not occur with specimens referred to other species. Such specimens have been observed in collections from the Millersburg and Tanglewood Limestone Members of the Lexington Limestone and from the Point Pleasant Tongue of the Clays Ferry Formation. Silicified specimens referable to $R$. ponderosa (Hall) are abundant in collections from the Millersburg Member. Specimens resembling $R$. declivis (James) are absent from all the collections except that from USGS loc. 7823-CO, in the lower part of the Tanglewood Limestone Member near Monterey, where ventral valves, but not dorsal valves, of this distinctively subtriangular species are common. 


\section{SYSTEMATIC PALEONTOLOGY}

\author{
Phylum BRACHIOPODA Duméril \\ Class ARTICULATA Huxley \\ Order STROPHOMENIDA Öpik \\ Suborder STROPHOMENIDINA Öpik \\ Superfamily STROPHOMENACEA King \\ Family OEPIKINIDAE Sokolskaya, 1960 \\ (nom. transl., emended, Pope, 1976)
}

Genus OEPIKINA Salmon, 1942

1942. Öpikina Salmon, Jour. Paleontology, v. 16, no. 5, p. 589-591. [pars] Rafinesquina, of authors.

Type species. -Öpikina septata Salmon, 1942, Jour. Paleontology., v. 16 , no. 5, p. 591-592, by original designation.

Diagnosis.-Outline shield-shaped; profile concavoconvex. Ornament finely and generally unequally parvicostellate. Pseudodeltidium arched, small; foramen minute or sealed. Pseudopuncta very fine and densely distributed. Teeth strong, blunt, semidenticulate; generally transversely grooved. Dental plates short. Notothyrial platform low and anchor-shaped. Medial ridge low and wide; breviseptum long. Two pairs of prominent trans-muscle ridges. Dorsal valve with conspicuous marginal rim.

\footnotetext{
Oepikina minnesotensis (Winchell), 1881

Plate 1, figures 1-14; plate 2, figures 1-12; plate 3 , figures 1-19; text-figures 1-11.
}

1881. Strophomena minnesotensis Winchell, Minnesota Geol. and Nat. History Survey, Ninth Ann. Rept., for 1880, p. 120-122.

1895. Rafinesquina minnesotensis Winchell and Schuchert, Minnesota Geol. and Nat. History Survey, Final Rept., v. 3, pt. 1, p. 401-403, pl. 31, figs. 25-26, 29.

1942. O. minnesotensis Salmon, Jour. Paleontology, v. 16, no. 5, p. 592-593, pl. 87, figs. 5-11.

1956. O. minnesotensis, Cooper, Smithsonian Misc. Colln., v. 127, p. 914, pl. 245, D, figs. 21-28.

1975. O. minnesotensis Bretsky and Bretsky, Geol. Soc. America Mem. 142, p. 9, 18, pls. 1-2.

Diagnosis. -Shells relatively small. Outline semicircular, slightly transverse or slightly elongate. Cardinal extremities orthogonal, rounded, or slightly alate. Convexity variable, low and smoothly curved to high with rounded geniculation. Costellae fine, uniform to weakly unequal. Teeth strong, transversely grooved. Diductor muscle scars oval, slightly impressed. Ventral adductor muscle scars on elongated ridges. Ventral valve with low submarginal rim. Dorsal trans-muscle ridges straight or with slight angular bend; highest toward anterior. Marginal rim of dorsal valve conspicuous.

Description.-Outline variable, generally slightly wider than long, rarely elongate (pl. 1 , fig. $3 a$ ) or nasute (pl. 1, fig. 13). Cardinal extremities orthogonal or slightly rounded (pl. 1, fig. 8b), rarely alate (pl. 1, fig. 12a). Convexity variable, from low and nongeniculate to highly domed, to high with rounded geniculation (pl. 1, figs. $1 c, 4 c, 5 c)$. Lateral margin slightly sinuous. Costellae fine, uniform in height (pl. 2, fig. 11) to irregularly unequal (pl. 2, fig. 12). Costellae along margin of ventral valve coarser (28-30 per $5 \mathrm{~mm}$ ) than along margin of dorsal valve (34-36 per $5 \mathrm{~mm})$ (pl. 2, figs. 10-12). Posterio-lateral rugae rare (pl. 1, fig. 10). Prominent growth interruptions common (pl. 1, figs. $8 b, 9 b$ ), correspond to position of geniculation. Pseudodeltidium small, flattened; medial groove. Supra-apical foramen small and sealed. Chilidium small, think and folded into cleft between cardinal process lobes (pl. 3, fig. $9 b$ ).

Teeth large and blunt, with deep transverse grooves and semidenticles (pl. 2, fig. 1d). Dental plates thick, short; merge into margin of diductor muscle scar. Pedicle callist bilobed (pl. 2, figs. $1 d, 4 b$ ). Diductor muscle scar oval to lanceolate; impressed into shell; radially ridged (pl. 2, figs. $3 b, 5,6$ ). Adductor muscle scars oval, at posterior ends of elongated ridges (pl. 2, figs. 5, 6). Adductor muscle ridges separated by a fine sharp ridge (pl. 2, fig. 5). Ventral valve with low submarginal rim (pl. 2 , figs. $1 b, 5)$. Ventral interior finely papillose.

Cardinal process lobes stout, erect hemicylinders (pl. 3 , figs. 1, 5, 9a). Myophores triangular, deeply cupped, facing posterior (pl. 3, figs. $9 b, 13 b, 16 b$ ). Socket buttress ridges short, thick, and recurved; sockets defined on posterio-lateral margin by a short sharp ridge (pl. 3, figs. $9 b, 13 b, 16 b)$. Notothyrial platform low and indistinct; medial ridge broad and low; breviseptum thin, sharp, and long (pl. 3, fig. 9a). Trans-muscle ridges thin, straight, or with slight angular bend; highest toward anterior ends (pl. 3, figs. 8, 9a, 13a). Adductor muscle scars indistinct. Circular submarginal rim variable in height, generally conspicuous (pl. 3, figs. 1, 2, 11, 13a). Internal surface finely papillose, with widely spaced endospines (pl. 3, fig. 9b).

Ontogeny.-Valves of Oepikina minnesotensis from Kentucky arranged in a sequence of increasing size, presumably from juvenile to adult, do not show marked change of outline shape throughout the sequence. The cardinal extremities, which generally are angular or slightly alate in small valves (pl. 1, fig. 12b; pl. 3, fig. 14), tend to be rounded in larger valves, perhaps partly because of abrasion. The convexity of small valves is consistently low and smoothly curved (pl. 1, figs. $12 b$, 14b). As a generality, the height of valves increases with increasir.y shell size, although a few relatively large valves have low convexity (pl. 2, fig. 3). The distance from the beak to the point of geniculation, if present, is not consistent. Geniculation does not seem to occur at a specific ontogenetic stage.

The costellae of small ventral valves and of the umbonal and central areas of large ventral valves are fine 
and uniform in height (pl. 1, figs. 11b, 12b, 14b). Costellae tend to become coarser and irregularly alternating toward the lateral and anterior margins of large ventral valves (pl. 1 , figs. $2 b, 3 b, 6 b$; pl. 2 , fig. 12 ).

Internally, small ventral valves (pl. 2 , figs. $7 b, 8 b$ ) lack the impressed diductor muscle scars and submarginal rim found in large valves (pl. 2, figs. 5, 6). Within dorsal valves, the socket buttress ridges and the posteriolateral socket ridges are thin and sharply defined (pl. 3, fig. 16b). These ridges become progressively thicker as valve size increases (pl. 3, fig. 9b), and the lateral ends of the sockets become closed by the recurved ends of the socket buttress riclges. Dorsal valves less than 10-12 $\mathrm{mm}$ long lack a submarginal rim (pl. 3, figs. 12, 15). The submarginal rim is initiated in valves $10-12 \mathrm{~mm}$ long and becomes higher and wider as valve size increases.

The relative prominence of the paired trans-muscle ridges of the dorsal valve changes ontogenetically. The posterio-lateral trans-muscle ridges enlarge first (pl. 3, figs. $12,14,15)$. The anterio-medial trans-muscle ridges subsequently increase in length and height until both pairs of ridges are about equal in prominence (pl. 3, fig. $13 a$ ). Thereafter, the anterio-medial ridges remain prominent, but the posterio-lateral ridges tend to become obscure or submerged by shell material (pl. 3, figs. $1,2,3,7)$.

Remarks on morphology. - The teeth of several large specimens of Oepikina minnesotensis from Kentucky bear semidenticles oriented perpendicular to the hingeline (pl. 2, fig. 1d). These semidenticles possibly have been accentuated by the silicification or etching process. The semidenticles are unusual, along with those of Strophomena verusta (figured by Pope, 1976, p. 139, fig. 4), in being on the dorsal surface of the tooth rather than along the delthyrial edge as in Rafinesquina (Pope, 1976 , p. 139, fig. 5) and in many other strophomenaceans. The position of the semidenticles of $O$. minnesotensis resembles the position of the denticles of Eostropheodonta. The semidenticles of 0 . minnesotensis, however, are more irregular in shape, more numerous, and more crowded than the denticles of Eostropheodonta, and they do not cause a corresponding denticulation of the dorsal hingeline. The dental crenulations of Oepikina minnesotensis are called "semidenticles" by convention. Whether these semidenticles are homologues of the semidenticles of Rafinesquina or of the denticles of Eostropheodonta cannot be determined from these specimens.

A transverse to oblique groove occurs in the teeth of many species of Oepikina, for example, in $O$. septata, $O$. speciosa, O. varia, and O. minnesotensis. The groove accommodates the posterio-lateral socket ridge. The posterio-lateral socket ridge consequently functioned as a secondary tooth. Few other concavo-convex strophomenaceans have such deeply grooved teeth, so this character permits differentiation of fragments of Oepikina from other concavo-convex genera such as Rafinesquina. Among resupinate species possessing prominent posterio-lateral socket ridges, the teeth are not grooved; rather, a pocket occurs between the dorsal surface of the tooth and the interarea (see Strophomena vetusta (James) in Pope, 1976, p. 138, fig. 1, "ath"; and p. 139, fig. 4, "aso").

Some specimens of Oepikina in the collections from Kentucky are not completely compatible in shape, ornament, or internal morphology with the definition of $O$. minnesotensis. These unusual specimens are few, occur within populations of $O$. minnesotensis, and, in some places, intergrade through other specimens into $0 . \mathrm{min}$ nesotensis. Consequently, these unusual specimens have not been identified as other species but are presumed to represent morphological extremes of $O$. minnesotensis.

The specimen shown on plate 1 , figure 3 , is quite elongate, whereas the specimen shown on plate 1 , figure 9 , is rather transverse. The specimen shown on plate 1 , figure 13 , is slightly nasute. The costellae of the specimen shown on plate 1 , figure $7 \mathrm{~b}$ are unusually uniform. The rugae of the specimen shown on plate 1 , figure 10 , are quite pronounced, and the radial wrinkles of the specimen shown on plate 3 , figure 15 are unique. The large ventral valves shown on plate 2, figures 3-4 have unusually low convexity. Additionally, the specimen of figure 4 has long dental plates, no semidenticles, an obscure diductor muscle field, and a curiously smooth internal surface. The dorsal valve shown on plate 3 , figure 2 , is quite large, and the myophores of the cardinal process are not as steeply inclined as those of other valves.

Polymorphism of O. minnesotensis. - Variation of size, outline shape, and profile are considerable among the specimens of Oepikina from USGS locs. 5078-CO and 7875-CO. Indeed, hasty inspection of these collections and comparison of morphologically extreme specimens within them may lead to the conclusion that several species occur, as implied in the previous section. However, the specimens of Oepikina from these two localities intergrade in size, outline shape, and profile, indicating that they are all members of a highly variable, that is, polymorphic, species. To depict the amount of variation within each collection and to compare the collections, histograms of length, width, height, and the $45^{\circ}$ diagonal radius, as well as scattergrams contrasting these dimensions are provided (text-figs. 1-9). Textfigure 10 summarizes these graphs.

Polymorphism has been shown to occur in strophomenacean species from other regions. For example, Alexander (1975) documented the polymorphism, which he called phenotypic plasticity, of Rafinesquina 


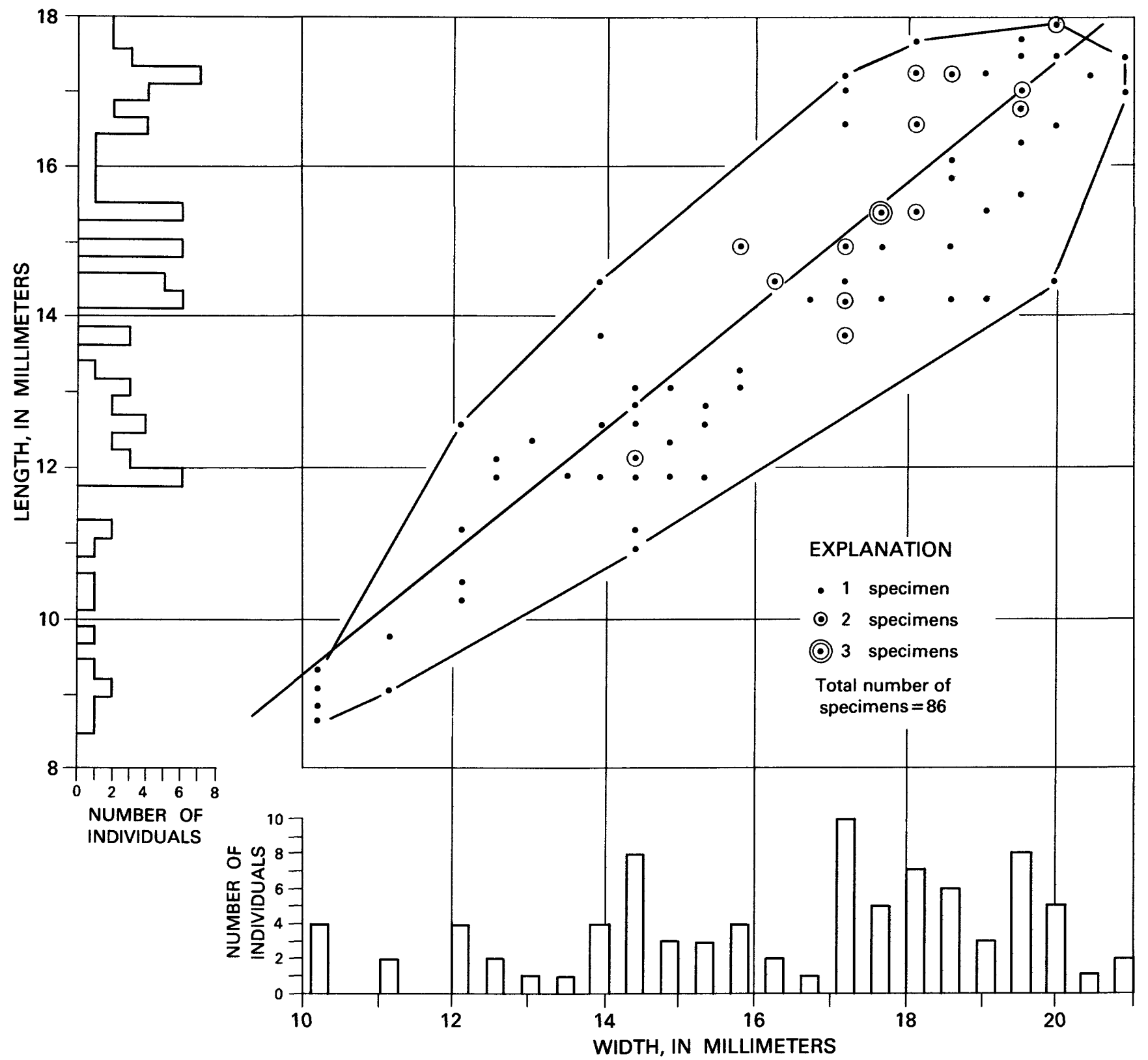

FIGURE 1. - Scattergram and regression line of length vs. width, and histograms of these measurements, for Oepikina minnesotensis from USGS loc. 5078-CO. Length was measured from center of hingeline (not from beak) to center of anterior margin to permit measurements from separated dorsal and ventral valves to be incorporated into this diagram. Additionally, measurement of length from hingeline to anterior margin permits data to be taken from specimens that have broken or abraded beaks. Width shown is maximum width exclusive of alae. Width of specimens that have one broken cardinal extremity was measured to midline of valve, and number was doubled to yield total width. Columns and tiers of points do not lie along whole-millimeter increments because specimens were measured optically magnified $\times 4.3$, and these data were used to construct the scattergram.

"alternata" from the Upper Ordovician of the Cincinnati area. He related the phenotypic plasticity to variations in the sedimentologic regime. Bretsky and Bretsky (1975) documented considerable polymorphism, especially of characters describing profile of the valves, in populations of $O$. minnesotensis and Strophomena plattinensis Fenton from the Platteville Formation of the northern Mississippi Valley region. Bretsky and Bretsky related the morphological variants and level of morphological heterogeneity within these species to the probable topography of the Plattville sea floor. They noted greater morphological uniformity in offshore populations and greater morphological variability within nearshore populations. 


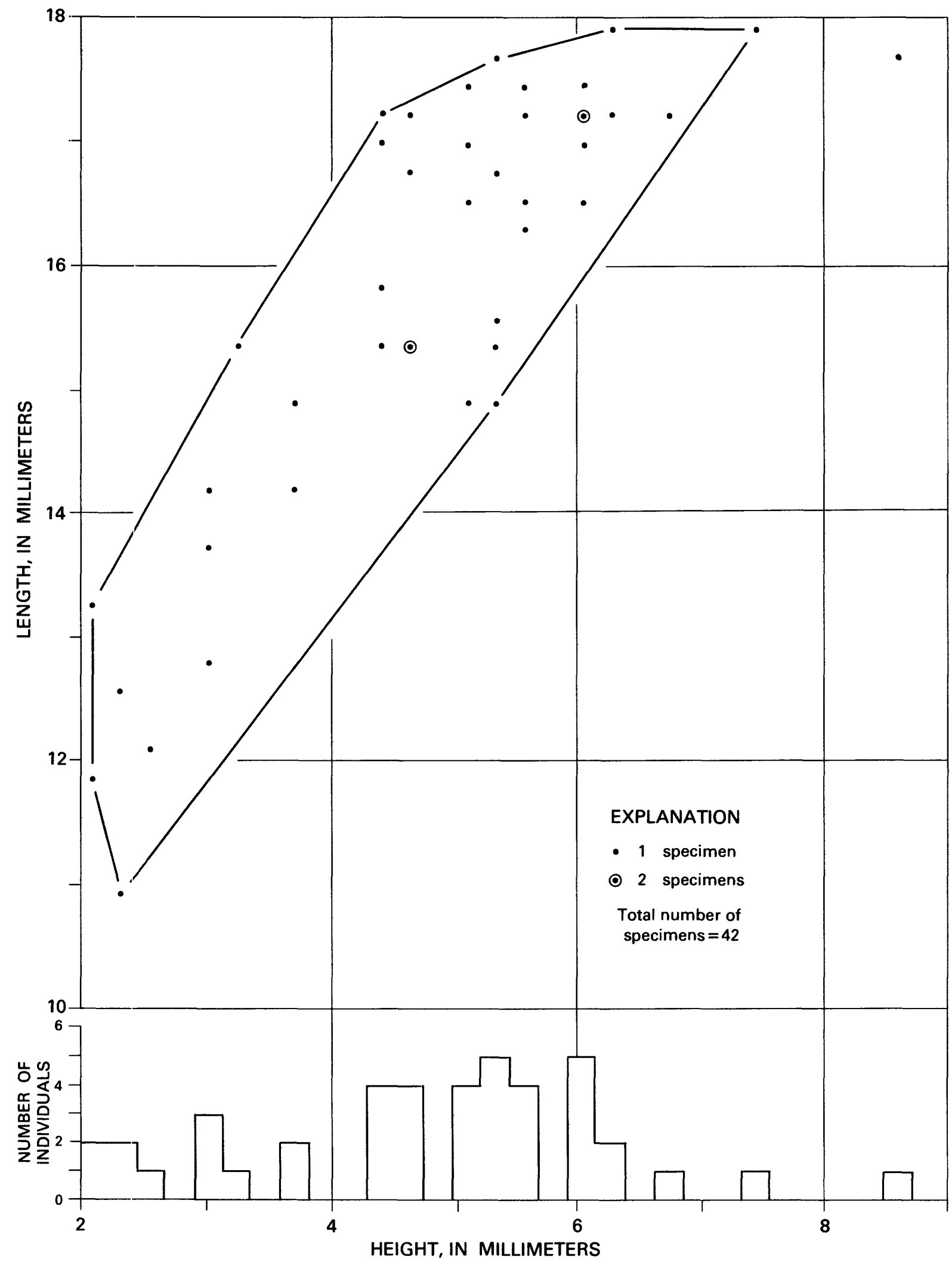

FIGURE 2. - Scaltergram of length vs. height, and histogram of height, for ventral valves of Oepikina minnesotensis from USGS loc. 5078-CO. See definition of length in caption for figure 1. Height was measured to highest point on valve above plane of conmissure. One anomalously high individual is not encircled. 


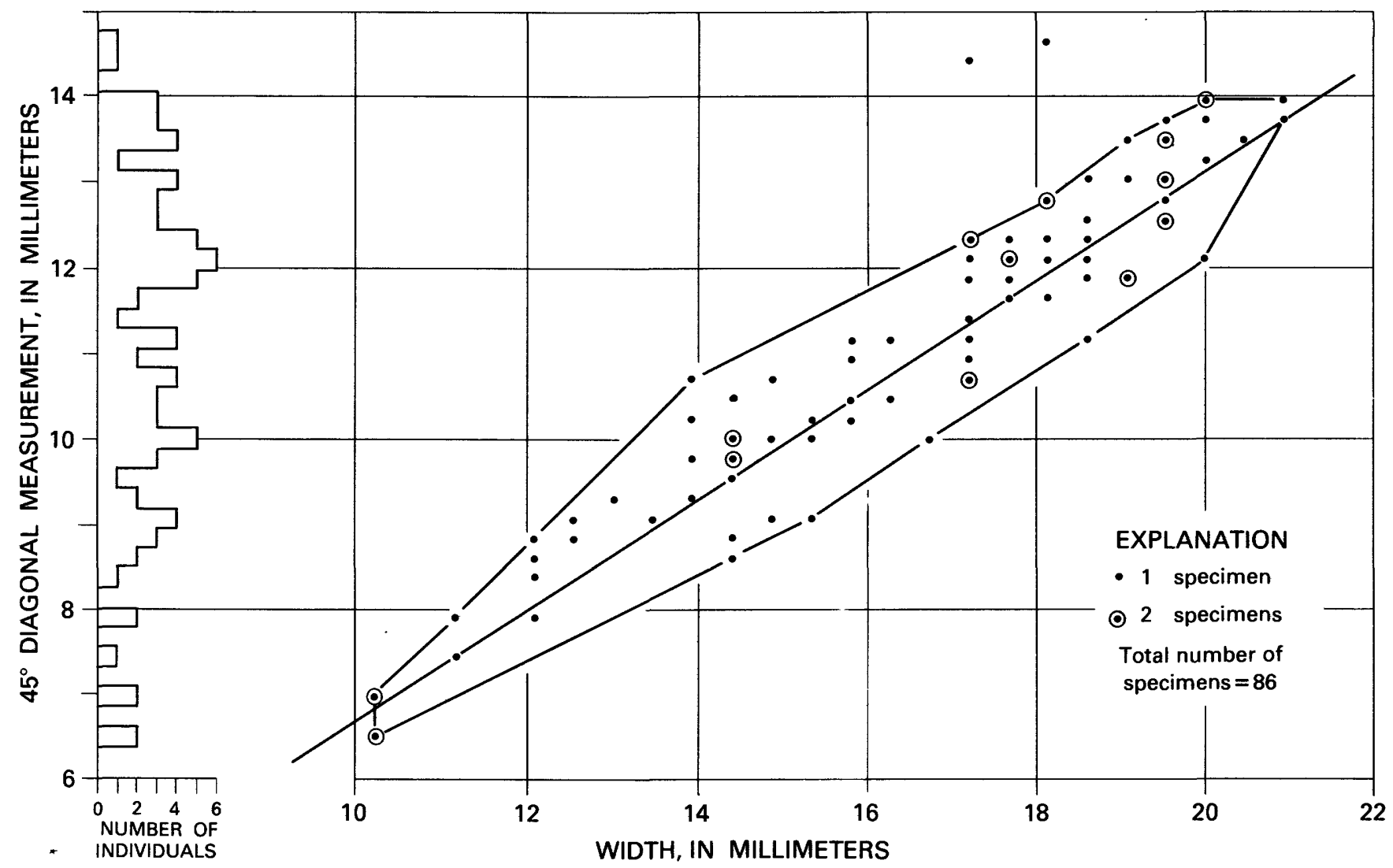

FiguRE 3.-Scattergram and regression line of $45^{\circ}$ diagonal measurement vs. width, and histogram of $45^{\circ}$ diagonal measurement, for Oepikina minnesotensis from USGS loc. 5078-CO. See definition of width in caption for figure 1 . Diagonal measurement is from center of hingeline to lateral margin of valve along a line set at $45^{\circ}$ to midline. Two anomalously subrectangular valves are not encircled. Otherwise, the scattergram shows that this population is consistent in outline shape.

Selection of individual specimens of 0 . minnesotensis from both populations suggests extreme variation in outline shape, from transverse through equidimensional to quite elongate individuals. The scattergrams of length vs. width for each population (figs. 1 and 4) however, show a reasonable interdependence of these dimensions. Comparison of the length-width scattergram fields from both localities (fig. 7) shows considerable overlap but not total conformity of the lengthwidth fields. Figure 7 and the correlation coefficients of length-width in figure 10 show that the specimens from USGS loc. 7875-CO are more variable in length-width relationship than are those from 5078-CO.

Variation within the two collections is also observed among specimens that are subrectangular, subcircular, or subtriangular in outline. To test the importance of these different shapes, scattergrams were constructed to contrast the width of specimens against the distance from the center of the hingeline to the lateral margin along a line set at $45^{\circ}$ to the midline (the $45^{\circ}$ diagonal radius). This relationship for each collection is shown in figures 3 and 6 , and the two collections are compared in figure 9. Again, there is a surprising degree of interdependence of these dimensions, but specimens from 7875-CO are more variable than are those from 5078-CO. The individuals in the two collections do not seem to be divisible into several species on the basis of outline shape.

The specimens of 0 . minnesotensis from Kentucky show greater variability in their height than in other dimensions plotted herein. The scattergrams of length vs. height, (figs. 2 and 5), which are compared in figure 8 , are rather broad and the correlation coefficients of $\mathrm{L} / \mathrm{H}$ (fig. 10) are somewhat lower than the other correlation coefficients. This relationship corresponds to the relationship of dimensions found by Alexander (1975, $p$. 611) for Rafinesquina "alternata," where the correlation coefficients of length vs. height have considerably lower values than those of length vs. width. Similarly, Bretsky and Bretsky (1975) found the amount of inflation of the valves of $O$. minnesotensis from the northern Mississippi Valley region to be highly variable. Scattergrams contrasting total length against distance from the beak to the initiation of geniculation for 0 . minnesotensis from 


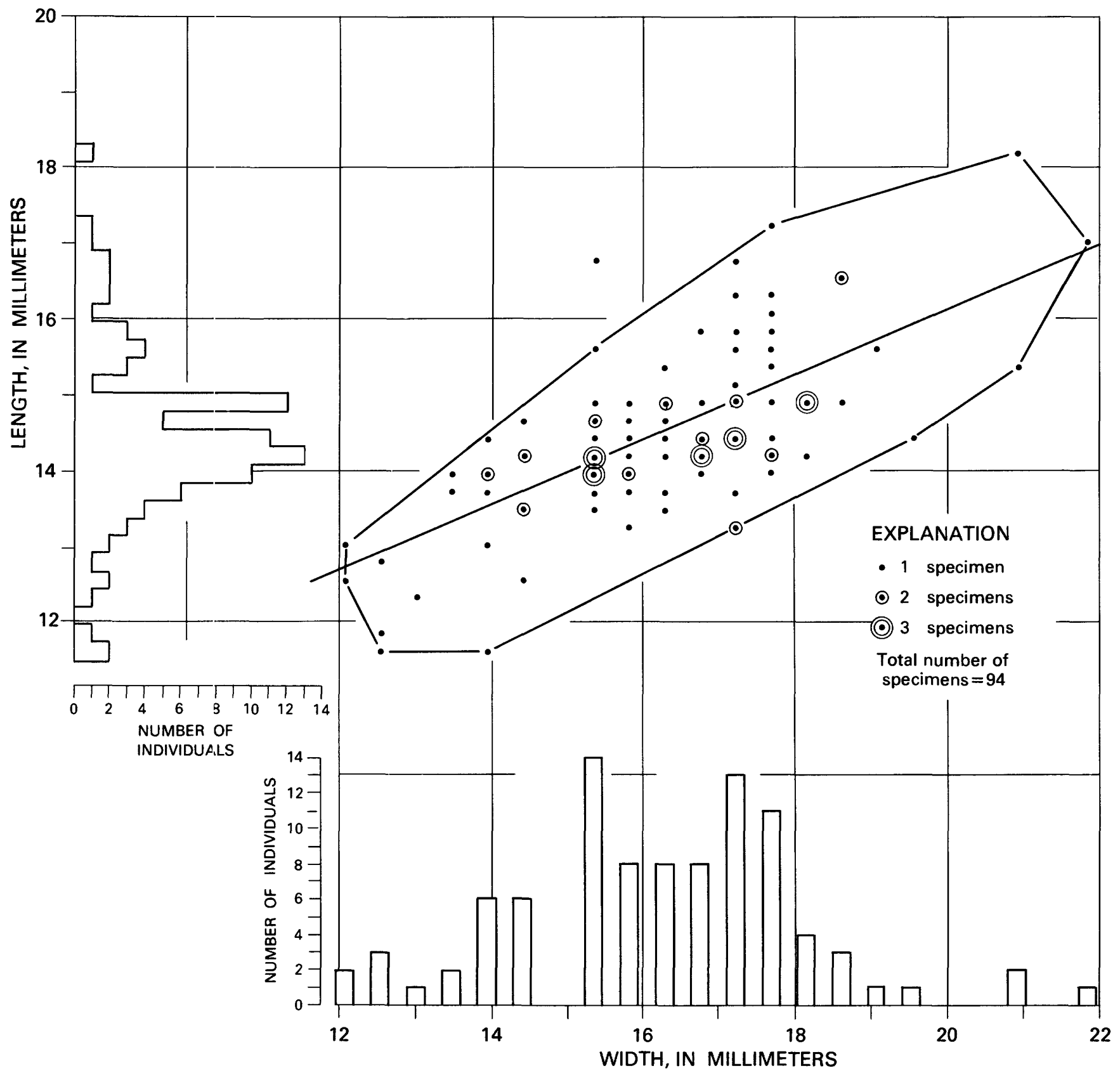

FiguRE 4.-Scattergram and regression line of length vs. width, and histograms of these measurements, for Oepikina minnesotensis from USGS loc. 7875-CO. See definitions of length and width in caption for figure 1. One anomalously long specimen is not encircled.

Kentucky, not included herein, have even lower correlation coefficients than those of length vs. height.

In the past, the alnount of inflation and the position of geniculation of strcphomenacean brachiopods has been thought to be a diagnostic characteristic of species. The beak-to-geniculation dimension may be a diagnostic characteristic of angularly geniculate forms such as Leptaena, where other characters such as ornament, thickness of the shell matter, and presence of endospines differ on either side of the line of inflection.
Among the shield-shaped less angularly geniculate strophomenaceans such as Oepikina, Rafinesquina, Strophomena, and Tetraphalerella, the height of the valves and the distance from the beak to the geniculation is variable and should not be relied upon exclusively to differentiate species.

The specimens of Oepikina from the two localities also show variation in qualitative, that is, subjectively appraised characteristics such as the nature of the costellae, size and shape of the cardinal process lobes, 


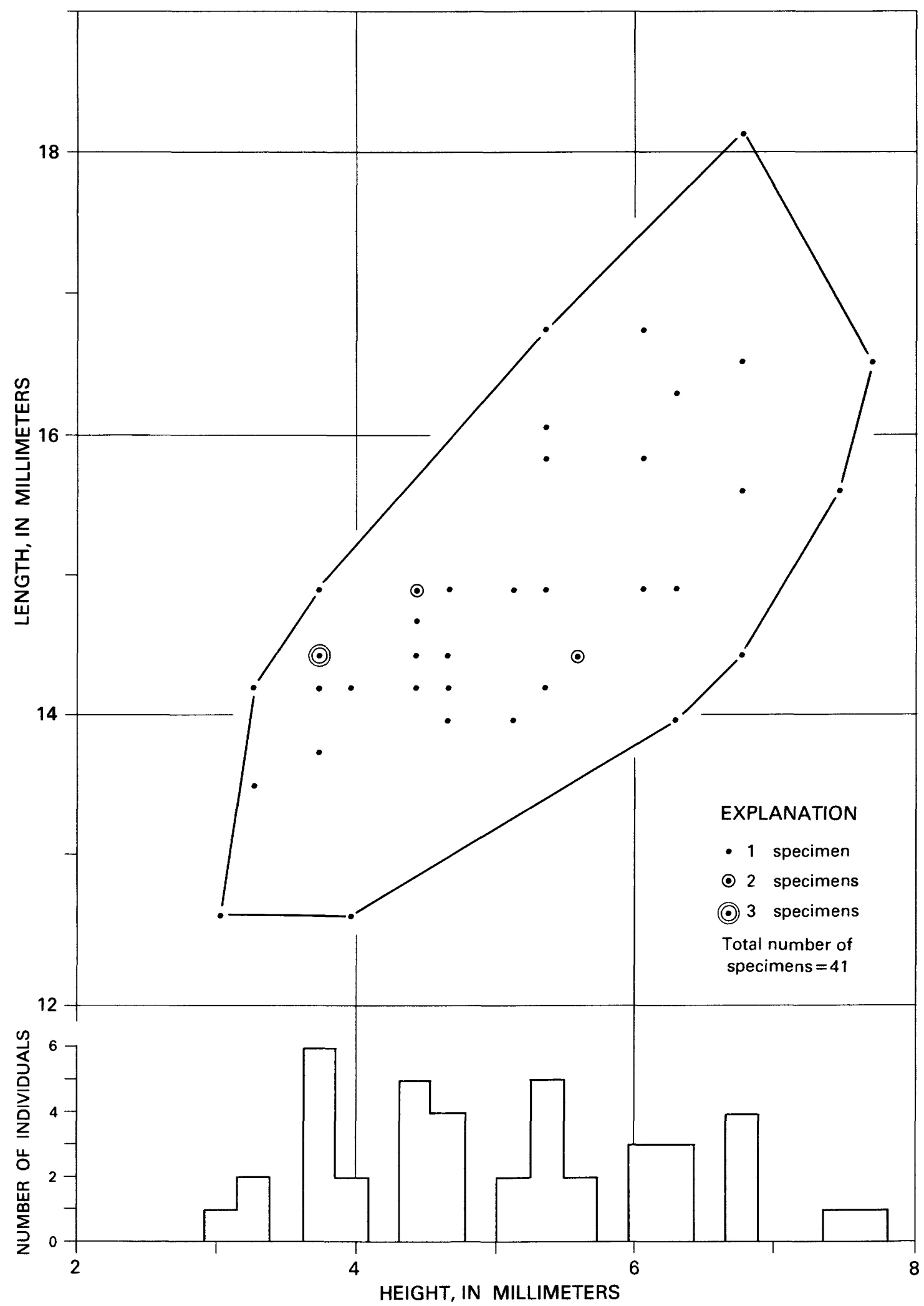

FIGURE 5. - Scattergram of length vs. height, and histogram of height, for ventral valves of Oepikina minnesotensis from USGS loc. 7875-CO. See definitions of length and height in captions for figures 1 and 2. 


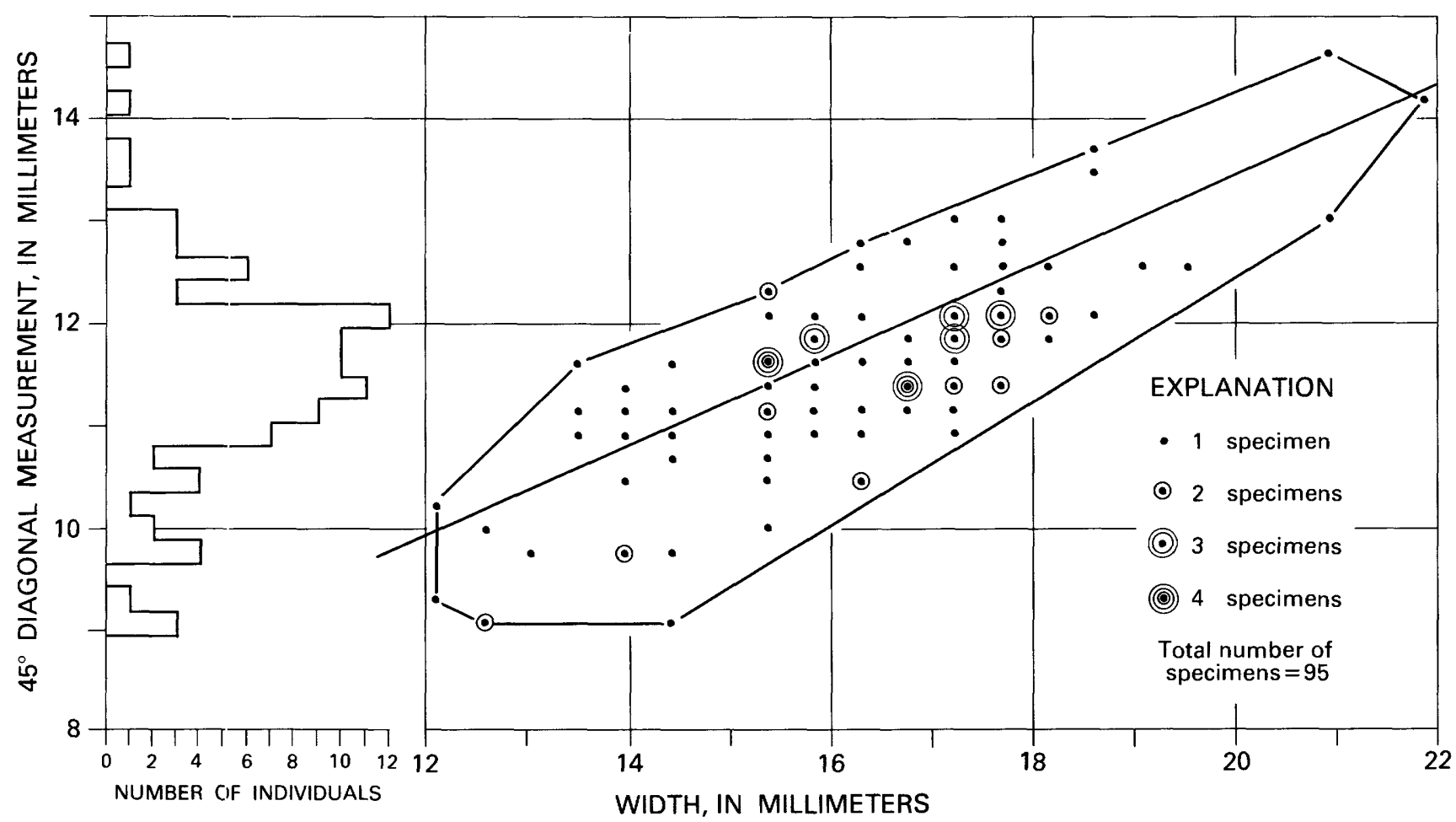

FigURE 6.-Scattergram and regression line of $45^{\circ}$ diagonal measurement vs. width, and histogram of $45^{\circ}$ diagonal measurement, for Oepikina minnesotensis from USGS loc. 7875-CO. See definitions of width and $45^{\circ}$ diagonal measurement in captions for figures 1 and 3.

height of the marginal rim, shape of the diductor muscle scars, and prominence of the dorsal trans-muscle ridges. Division of the collections into groups of specimens bearing extreme variations of the above characteristics, for example, those having unusually large cardinal-process lobes or unusuilly uniform costellae, does not automatically segregate individuals bearing extreme variations of outline, profile, or other subjectively appraised characters. Finally, if specimens possessing each extreme type of outline shape, profile, or ornament were placed in a separate species, at least six sympatric species would have to be recognized in the collections from USGS locs. 5078-CO and 7875-CO. This would be ecologically unlikely. Consequently, only one polymorphic species, Oepikina minnesotensis, is recognized in these collections.

Comparison.-O. minnesotensis from Kentucky is differentiated from some other species of Oepikina by size and length/width ratio (fig. 11, lower diagram). The field representing length vs. width for 0 . minnesotensis from Kentucky (fig. 11, upper diagram) overlaps the plexus of points constructed from measurements taken from the illustrations of $O$. ininnesotensis by Bretsky and Bretsky (1975).
Several species of Oepikina-O. speciosa Cooper, $O$. gregaria Cooper, $O$. formosa Cooper, and $O$. varia Cooper-seem generally to lie along the same length/width axis and to have approximately the same size as $O$. minnesotensis. This necessitates differentiation of these species on qualitative characteristics.

$O$. speciosa is larger than $O$. minnesotensis and has a more strongly defined notothyrial platform and dorsal medial ridge than does $O$. minnesotensis. Cooper $(1956$, p. 920) differentiated $O$. speciosa from $O$. inquassa (Sardeson) on beak-to-geniculation distance. Cooper's illustrations of $O$. speciosa (1956, pl. 238, figs. 6-7) have a strong resemblance to the syntype of $O$. inquassa figured by Salmon (1942, pl. 87, fig. 14). In turn, these specimens resemble those of $O$. minnesotensis shown on plate 3 , figures 2 and 3 of this report. Winchell and Schuchert (1895) concluded that Strophomena inquassa Sardeson was a variety of Rafinesquina minnesotensis (Winchell). These three species might prove to intergrade if larger populations were studied. Regardless of how this matter eventually may be resolved, $O$. inquassa as presently identified is larger and more subcircular than is $O$. minnesotensis and has more conspicuous (?gerontic) internal features. 


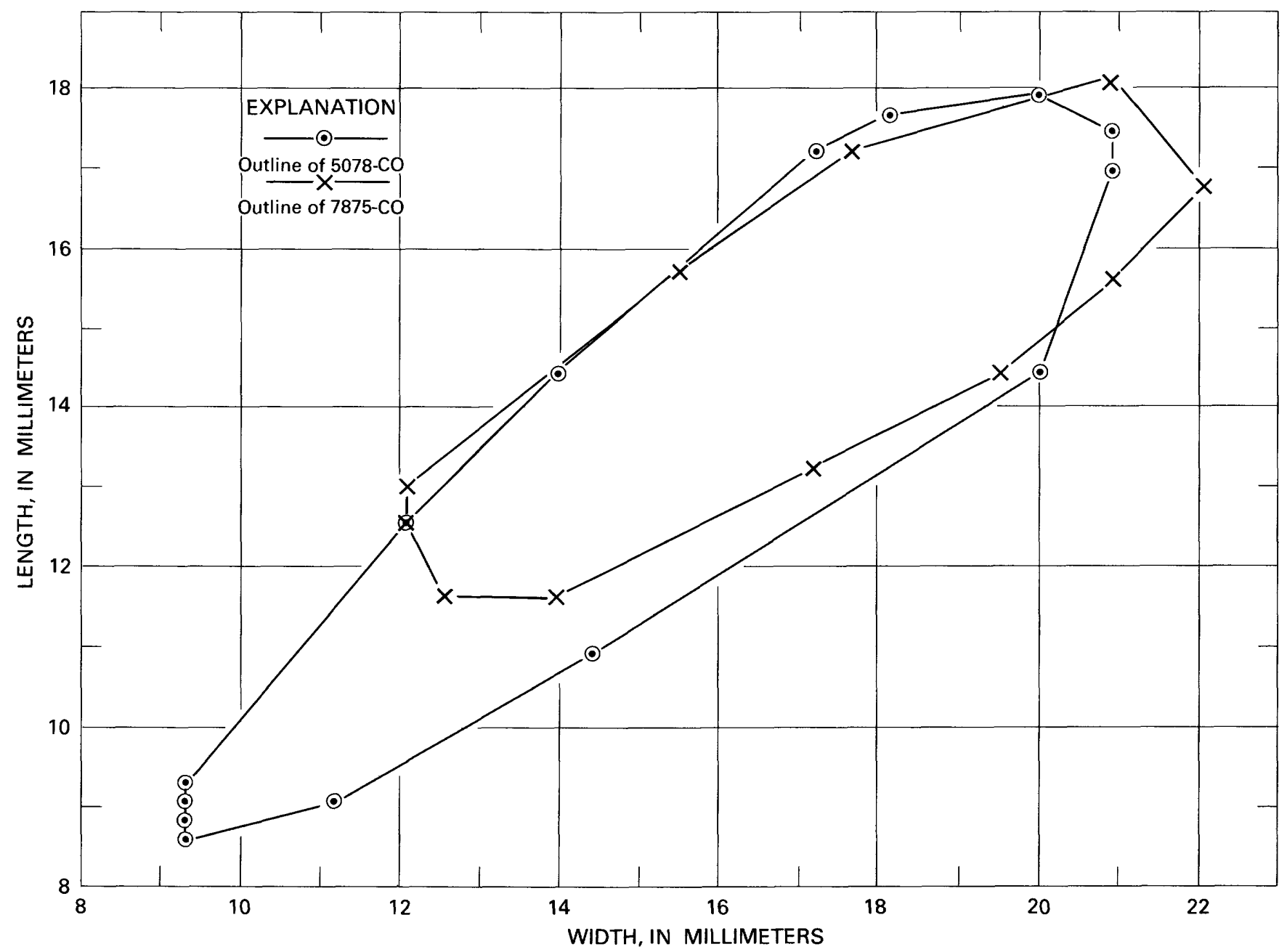

FIGURE 7.-Combined outlines of scattergrams of length vs. width for Oepikina minnesotensis from USGS locs. 5078-CO and 7875-CO.

O. gregaria is smoother, has finer costellae, is more alate, has more delicate dorsal trans-muscle ridges, and has wider socket buttress ridges than does O. minnesotensis. These species are probably distinct.

$O$. formosa is distinguished from $O$. minnesotensis by its sharply defined, somewhat wavering costellae, wide socket buttress ridges, and a bifurcation or alveolus at the anterior end of the dorsal medial ridge.

$O$. varia has a small diductor muscle scar, elevated notothyrial platform and dorsal medial ridge, and thick, short dorsal trans-muscle ridges, which set it apart from O. minnesotensis.

O. transitionalis (Okulitch) presents a problem. The holotype, a deformed and incomplete ventral valve, does not contain enough information to permit recognition of the species. It is larger than any specimen of 0 . minnesotensis from Kentucky. The plesiotype figured by Salmon (1942, pl. 87, fig. 18), a dorsal interior, is only slightly larger than the largest 0 . minnesotensis and might lie within a reasonable extension of the length/ width scattergram of the Kentucky specimens. This plesiotype specimen differs from $O$. minnesotensis from Kentucky by being slightly more subtriangular and alate and by having a thickened breviseptum and short thick anterio-medial trans-muscle ridges. The position and angle of geniculation and amount of alation, according to the descriptions of Salmon, should separate these species. I am not convinced that these are diagnostic characteristics; hence, lacking description of a population of $O$. transitionalis, I cannot draw a conclusion regarding the distinction of these species.

The Oepikina populations. - The collections of O. $\mathrm{min}$ nesotensis from USGS locs. 5078-CO and 7875-CO seem to be samples of largely biocoenosic populations. In fact, the collections possibly represent samples of populations that began on the sea floor with one major influx of spat and then slowly diminished in numbers because of episodic mortality. This conclusion is based upon the considerable range of sizes among individuals in both populations, especially from loc. 5078-CO, survivorship 


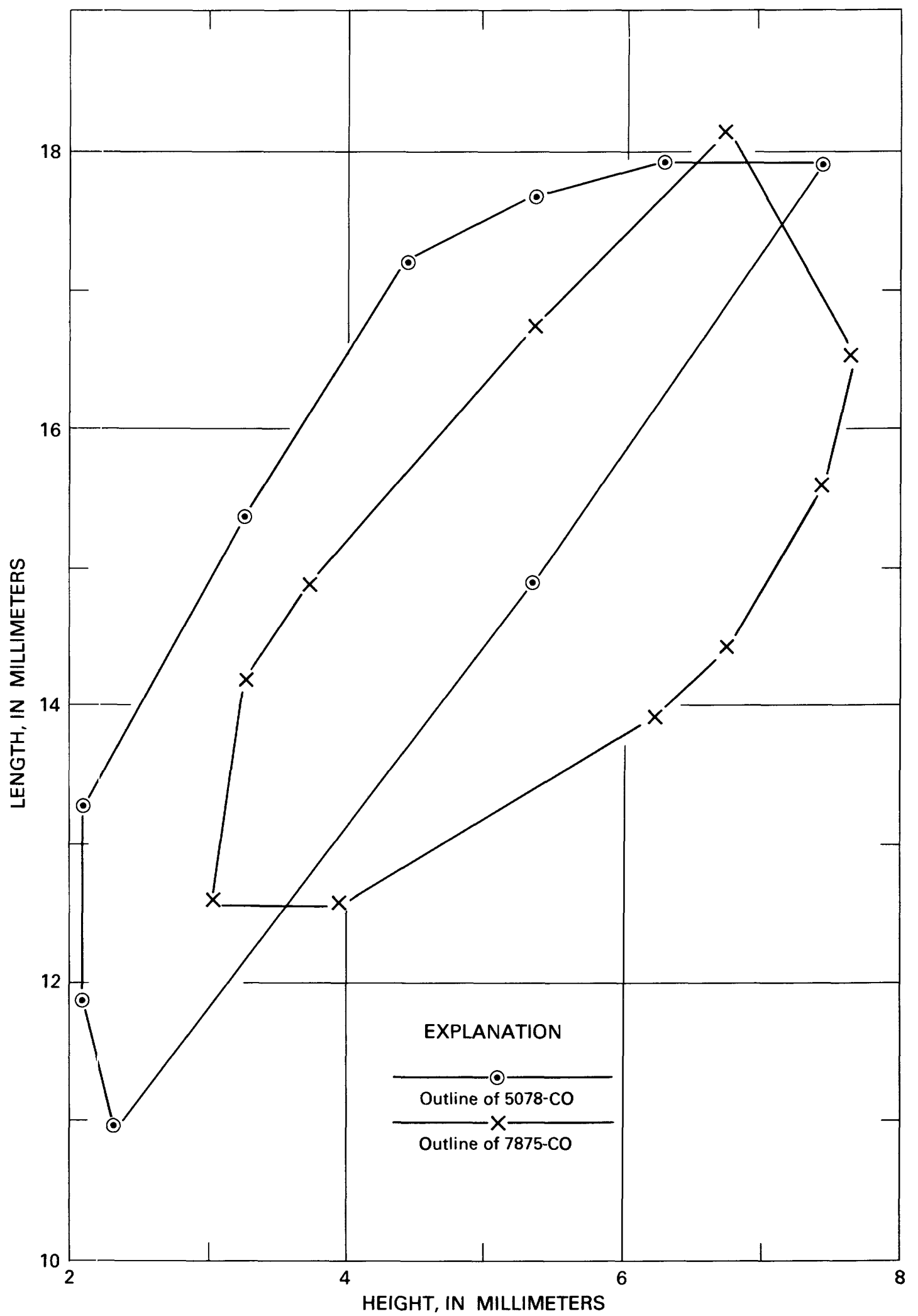

FIGURE 8. - Combined outlines of scattergrams of length vs. height for Oepikina minnesotensis from USGS locs. 5078-CO and 7875-CO. 


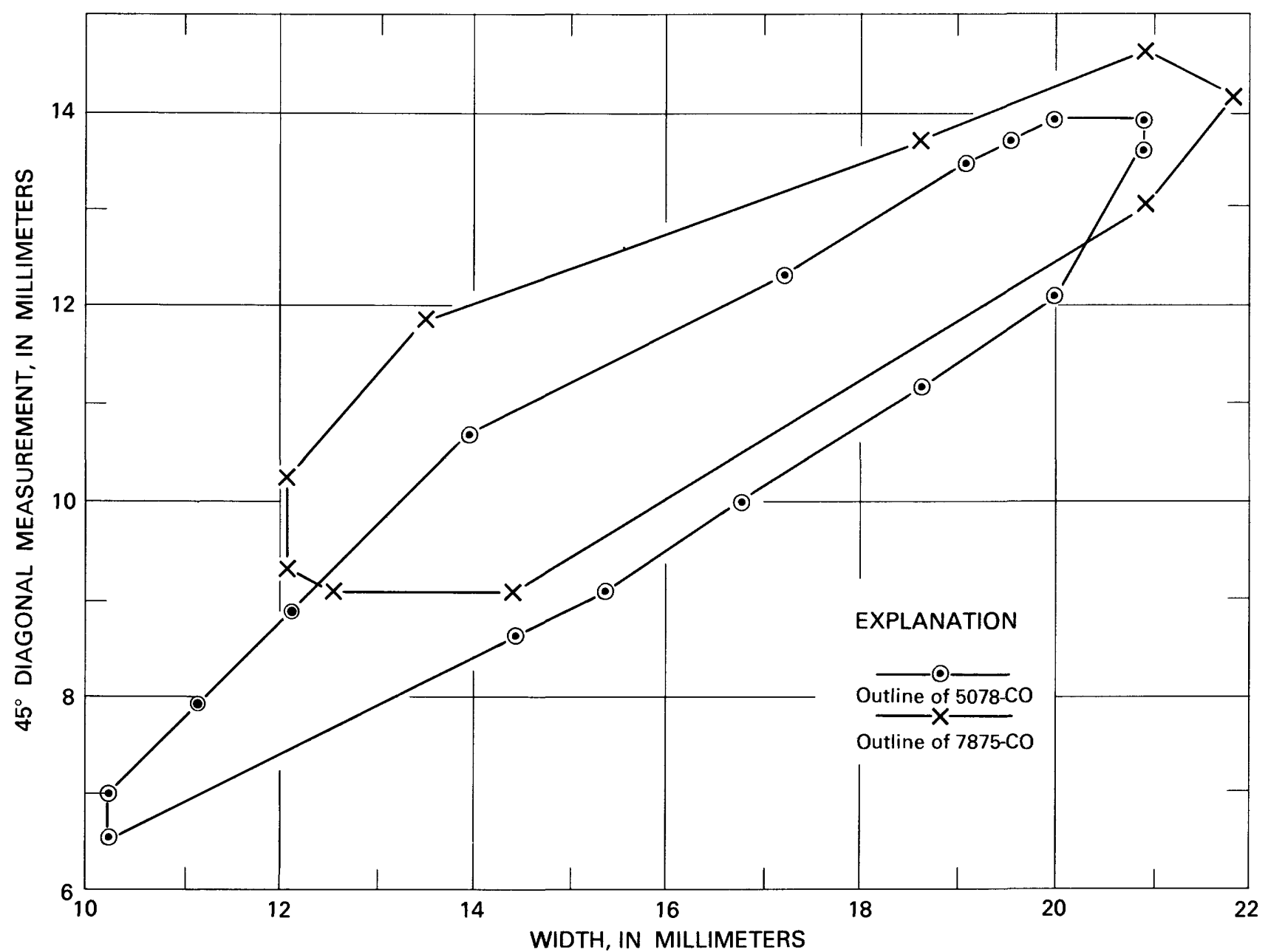

FIGURE 9. - Combined outlines of scattergrams of $45^{\circ}$ diagonal measurement vs. width for Oepikina minnesotensis from USGS locs. 5078-CO and 7875-CO.

curves, and what appears to be a repeated pattern of growth interruptions on many of the ventral valves.

Despite the fact that many of the specimens in both collections are disarticulated, articulated specimens of different sizes are found. Size-selective preservation or size sorting like that reported by Richards and Bambach (1975, p. 777) for Rafinesquina from the Richmondian Stage does not seem to have taken place. Simple disarticulation without fragmentation or size sorting of strophomenacean brachiopods is not necessarily indicative of long-range transport of the individuals. The strophomenacean hinge, with its wide delthyrial angle, deltidiodont tooth form (Jaanusson, 1971, p. 36), and trough-shaped sockets probably did not lock the valves together positively. This permitted the valves to disarticulate with but slight disturbance or overturning after death and decay of the adductor muscles. Currents on the sea floor where these Oepikina populations lived possibly were competent only to overturn the shells but not to fragment them or to remove at least those in the 9-18-mm-long size range. (Actually, valves smaller than $9 \mathrm{~mm}$ long occur in both collections, but all these very small specimens are incomplete owing to lack of silicification of the thin margin of the shell or to fracture during or after etching of the shells from the limestone.)

Many of the ventral valves from USGS loc. 5078-CO bear a major growth interruption, which delineates a central shell region of about the same size (pl. 1, figs. $6 b$, $8 b, 9 b, 10,11 b, 12 b)$. This growth interruption commonly initiates geniculation. On many of the valves, this major growth interruption is followed a short distance toward the margin by a second, less pronounced interruption. These growth interruptions may record the same two adverse events in the growth of these individuals.

The histograms for length and width of $O$. minnesotensis from 5078-CO (fig. 1) show a rather rhythmic rise and fall. These histograms resemble the histogram of length presented by Walker and Parker (1976, p. 196) in 


\begin{tabular}{|c|c|c|c|c|c|}
\hline U.S.G.S. loc. & Statistics & Length & Width & Height & $45^{\circ}$ Diagonal \\
\hline \multirow{3}{*}{$5078-\mathrm{CO}$} & Mean & 14.22 & 16.43 & 4.81 & 11.08 \\
\hline & Standard deviation & 2.48 & 2.48 & 1.46 & 1.96 \\
\hline & Variation $\left[\frac{100 \mathrm{~s}}{\overline{\mathrm{x}}}\right]$ & 17.44 & 17.28 & 30.35 & 17.68 \\
\hline \multirow{3}{*}{$7875-\mathrm{CO}$} & Mean & 14.46 & 16.23 & 5.06 & 11.55 \\
\hline & Standard deviation & 1.16 & 1.85 & 1.21 & 1.04 \\
\hline & Variation $\left[\frac{100 \mathrm{~s}}{\overline{\mathrm{x}}}\right]$ & 8.02 & 11.39 & 23.91 & 9.00 \\
\hline U.S.G.S. loc. & Regression line & $\mathrm{L} / \mathrm{W}$ & $\mathrm{L} / \mathrm{H}$ & $45^{\circ}$ & Diagonal/W \\
\hline \multirow{3}{*}{$5078-\mathrm{CO}$} & Slope & 0.799 & 1.05 & 0.646 & \\
\hline & Y intercept & 1.09 & 10.65 & .45 & \\
\hline & Correlation coefficient & .916 & .848 & .936 & \\
\hline \multirow{3}{*}{$7875-\mathrm{CO}$} & Slope & 0.422 & .616 & 0.433 & \\
\hline & $\mathrm{Y}$ intercept & 7.6 & 11.7 & 4.51 & \\
\hline & Correlation coefficient & .0671 & .667 & .768 & \\
\hline
\end{tabular}

FIGURE 10.-Summery of statistics for Oepikina minnesotensis from USGS locs. 5078-CO and 7875-CO. All measurements in millimeters.

their detailed analysis of Strophomena basilica Cooper from the Middle Ordovician of Tennessee. The several crests of the length and width histograms for $O$. minnesotensis probably evidence episodic (seasonal?) mortality in this brachiopod population, just as they do on the length histogram for $S$. basilica.

Size-frequency distribution diagrams for the two populations show left-skewed distributions. Survivorship curves for both populations, constructed according to the method of Richards and Bambach (1975), are convex. These patterns suggest that both populations were subject to low infant mortality and increased mortality among ephebic and gerontic individuals. The crests of the histograms, thus, should not be interpreted as successive (annual) spatfalls in a population extinguished by one event, because such a scenario would yield a large proportion of snall valves (right-skewed distribution diagrams and concave survivorship curves). The alternative model, that of a single large spatfall, followed by high infant survival, followed by episodic mortality, may have been the more likely history of these populations.

Occurrence and specimens. - Silicified specimens of $O$. minnesotensis have been recovered from four localities in Kentucky (table 1).

\section{Family STROPHOMENIDAE King, 1846 Subfamily FURCITELLINAE Williams, 1965 \\ Genus FURCITELLA Cooper, 1956}

1956. Furcitella Cooper, Smithsonian Misc. Colln., v. 127, pt. 1, p. 875-877.

[pars] Strophomena, of authors.

Type species. -Furcitella plicata Cooper, 1956, p. 877-878, by original designation.

Diagnosis. - Shells small; outline transversely semicircular to subrectangular. Profile unequally biconvex. Shell not prominently folded. Costellae not prominently alternate. Foramen open. Diductor muscle field subrhombic; muscle bounding ridge thin, incomplete. Medial ridge of dorsal valve bifurcate; trans-muscle ridges generally weak, abruptly bent.

TABLE 1.-Localities from which silicified specimens of Oepikina minnesotensis were recorded in Kentucky

[USGS locs. 5078-CO and 7875-CO are in the Camp Nelson Limestone near High Bridge, Ky. Loc. 7835-CO is in the Camp Nelson Limestone, along U.S. Route 27, 1 mile north of the Kentucky River. The exact locality of one specimen is not known, but the specimen is from the High Bridge Group in Kentucky. Figured specimens on plates 1-3 are numbered USNM 245277 to 245318]

\begin{tabular}{ccccl}
\hline USGS loc. & No. of ventral valves & No. of dorsal valves & $\begin{array}{c}\text { No. of articulated } \\
\text { specimens }\end{array}$ & Comments \\
\hline $5078-\mathrm{CO}$ & 78 & 57 & 3 & $\begin{array}{c}\text { Plus many fragments. Fine-grained, dense surface silicifi- } \\
\text { cation. }\end{array}$ \\
\hline $7875-\mathrm{CO}$ & 74 & 67 & 5 & Plus many fragments. All specimens coarsely silicified \\
\hline $7835-\mathrm{CO}$ & 2 & 2 & 1 & Plus many fragments. All specimens poorly preserved \\
\hline Unknown & 0 & 0 & 1 & Coarsely silicified, no ornament \\
\hline
\end{tabular}




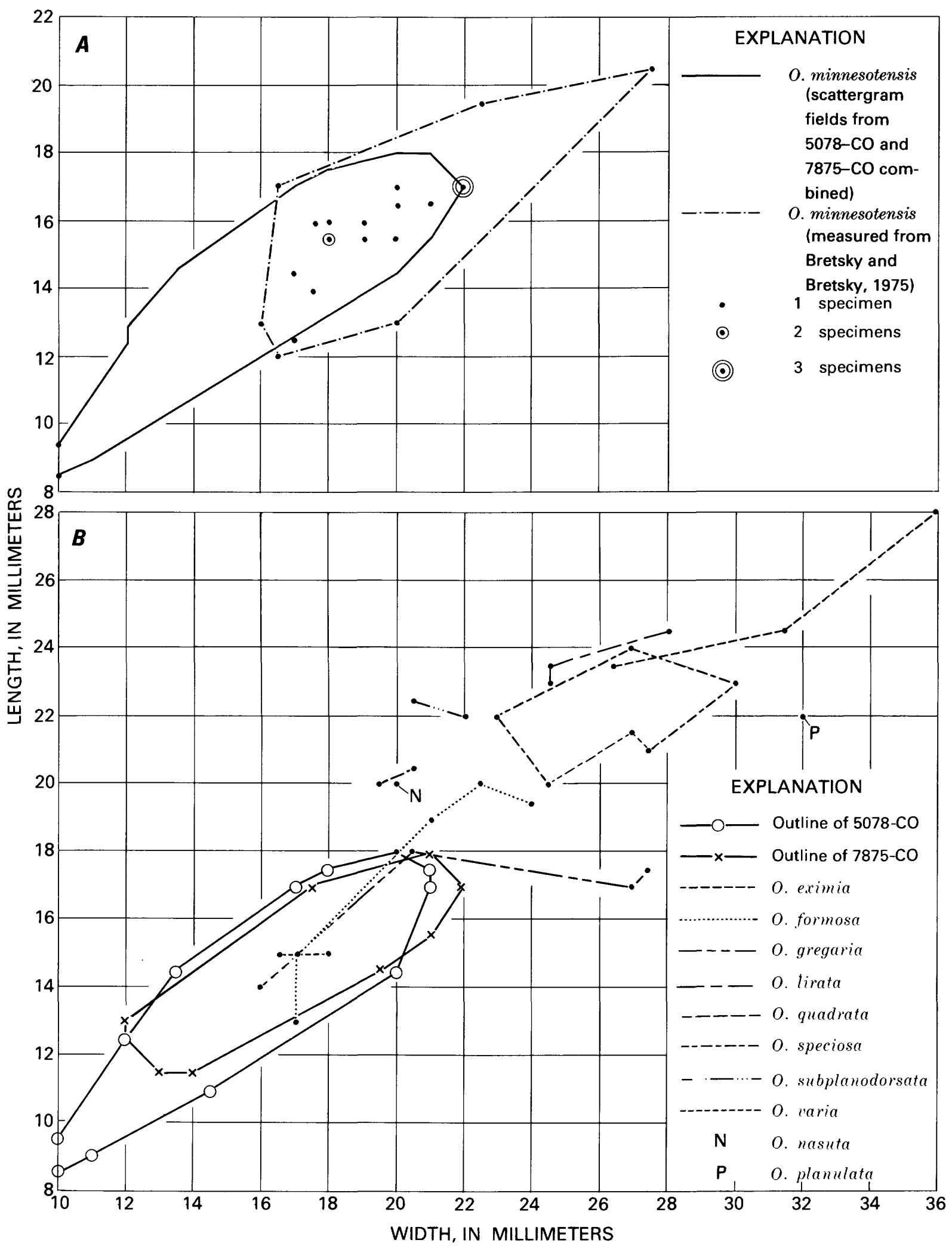

FIGURE 11. $-A$, Comparison of combined scattergram fields of length vs. width for Oepikina minnesotensis from Kentucky (indicated by solid line) with measurements of length and width taken from published photographs (Bretsky and Bretsky, 1975) of $O$. minnesotensis from the northern Mississippi Valley (Wisconsin, Illinois, Iowa, and Minnesota). $B$, Comparison of scattergram fields of length vs. width for $O$. minnesotensis from Kentucky with published length and width measurements (Cooper, 1956) of other species of Oepikina. 
Description. - Shells small; outline transversely semicircular to subrectangular; cardinal extremities orthogonal. Profile unequally biconvex; dorsal valve more uniformly and strongly domed than ventral valve; ventral valve flattened or slightly concave near anterior margin. Anterior margin rectimarginate to weakly plicate. Ventral interarea moderately long; pseudodeltidium arched; chilidium small; foramen open. Costellae moderately fine, uniform in width and height; growth interruptions common. Surface of valves uneven, irregularly undulating. Pseduopuncta fine.

Teeth strong; dental plates short and vertical. Diductor muscle field stibrhombic, bounded laterally by thin low ridges. Adductor muscle scars long, narrow, slightly elevated, and divided by low medial ridge.

Cardinal process; lobes low and cupped; notothyrial platform short and high. Sockets short, straight, and widely divergent. Medial ridge of dorsal valve bifurcate; breviseptum faint. Trans-muscle ridges weak, abruptly bent.

Remarks. -Furcitella and Holtedahlina are closely related, as noted by Cooper (1956, p. 876). These genera are distinguished from other closely related genera such as Trigrammaria and Microtrypa by their biconvex profiles, open foramina, and uniform costellae, and from Murinella by the absence of a marginal flange within the dorsal valve. Furcitella and Holtedahlina are differentiated by the presence of a dorsal fold in adult specimens of Holtedahlina (pl. 7, figs. 11, 12) and a prominent bifurcation of the d.orsal medial ridge of adult specimens of Furcitella (pl. 5, figs. 2b-d). In reality, immature specimens of Holtedahlina sulcata (de Verneuil), type species of Holtedohlina, conform to the diagnosis of Furcitella. The differences between these genera, consequently, must be regarded as late ontogenetic additions to Holtedahlina. The species of these genera may constitute a chronocline extending from the Middle Ordovician through the Upper Ordovician, but at present, a deficiency of species from the upper Middle Ordovician and lower Upper Ordovician interrupts the speculative sequence.

Small specimens of Holtedahlina sulcata do not have a dorsal fold and as a result resemble Furcitella in anterior view. The fold begins when specimens achieve about one-third adult length, becomes higher and sharper as size increases (pl. 7, figs. 11-12), and is especially pronounced in large individuals that occur in clusters. The strength of folding, thus, seems to be related to both ontogenetic stage and population density.

The dorsal medial ridge of immature specimens of $H$. sulcata is bifurcate (pl. 7, fig. 10), although the split ends are not as long as those of Furcitella (pl. 5, figs. 2b-d). The split ends of the medial ridge of $H$. sulcata are not ridges set on either side of the anterior termination of the medial ridge, as interpreted by Cooper (1956, p. 876). As shell size increases, the ends of the medial ridge of $H$. sulcata progressively enlarge to create a pair of closely spaced, rounded lobes (pl. 7, fig. 11) from which emerges the breviseptum.

Bifurcation of the medial ridge is not an exclusive attribute of the Furcitellinae; it occurs inconsistently in other genera of the Strophomenacea. For example, this character is found at least in some species of Dactylogonia, Bellimurina, Cyphomena, Microtrypa, Oepikina, Maakina, and Strophomena. The presence of the bifurcation seems to be related to the ontogenetic stage of specimens, being generally absent or obscure in quite small specimens and commonly submerged by shell material in unusually large specimens.

The pairs of trans-muscle ridges are not as evident in Furcitella as they are in Holtedahlina. Immature specimens of Holtedahlina sulcata have sharply defined posterio-lateral trans-muscle ridges and obscure anterio-medial trans-muscle ridges (pl. 7, fig. 10), the condition found in Furcitella. As shell size increases, the posterio-lateral trans-muscle ridges of Holtedahlina become submerged by shell matter and a lyre-shaped pair of anterio-medial trans-muscle ridges develops. The anterio-medial trans-muscle ridges arise from nodes adjacent to the lobate ends of the medial ridge (pl. 7, fig. 11). This produces a transverse row of four nodes, a condition not observed in Furcitella.

Furcitella cf. F. scofieldi (Winchell and Schuchert)

Plate 5, figures 1-6; plate 6, figures 3-6

1892. Strophomena scofieldi Winchell, and Schuchert, Am. Geologist, v. 9, p. 286-287.

1895. S. scofieldi Winchell, and Schuchert, Minnesota Geol. and Nat. History Survey, v. 3, pt. 1, Paleontology, ch. 5, p. 398-399, pl. 31 , figs. 18-21.

1956. Furcitella scofieldi Cooper, Smithsonian Misc. Colln., v. 127, pt. 1-2, p. 878, pl. 229, A, figs. 1-5; pl. 265, C, fig. 6, [? fig. 5].

Diagnosis.-Outline transversely subrectangular to semicircular. Profile unequally biconvex; ventral valve flattened to concave in central region. Anterior commissure weakly uniplicate to undulating. Costellae moderately fine, somewhat discontinuous; surface of valve irregularly wrinkled. Diductor muscle field oval to rhombic. Dorsal medial ridge relatively narrow; transmuscle ridges low, short, abruptly bent.

Description.-Shells small. Outline transversely subrectangular (pl. 6, fig. 5) to semicircular; cardinal extremities orthogonal to slightly obtuse and rounded, rarely acute. Profile unequally biconvex; dorsal valve planate toward posterior, strongly curved to anterior; ventral valve gently convex toward posterior, flattened to gently concave in central to anterior region. Anterior 
commissure rectimarginate to weakly uniplicate (pl. 5 , fig. $3 c$ ) to gently undulating (pl. 6 , figs. $3 a, 5 b$ ). Costellae moderately fine ( 15 to 16 per $5 \mathrm{~mm}$ ), closely spaced, relatively uniform in height, but tending to be discontinuous and wavering in direction (pl. 5 , figs. $2 e, 5 c ; \mathrm{pl}$. 6 , fig. $3 d$ ). Growth interruptions and comae common (pl. 5, fig. 2a; pl. 6, fig. $6 a$ ); surface of valves gently and irregularly wrinkled (pl. 5, fig. la). Pseudodeltidium short, gently arched (pl. 6, figs. 3c, 5e); foramen open, moderately large, apical (pl. 6, fig. $5 d$ ). Chilidium thin, protruding, folded into meso-cardinal cleft.

Teeth small but strong and blunt (pl. 6, fig. 5e); dental plates vertical to slightly flared, slightly receding (pl. 6 , fig. $5 d$ ). Diductor muscle field oval (pl. 6 , figs. $5 c, 6 b$ ) to rhombic (pl. 6, fig. 3c). Muscle-bounding ridge low, incomplete. Medial ridge of diductor muscle field low and short; adductor muscle scars elevated (pl. 6, fig. 3c).

Cardinal process lobes narrow, myophores deeply cupped (pl. 5, figs. $1 c-e, 2 c-d$ ). Meso-cardinal ridge thin, low. Notothyrial platform short, high (pl. 5, fig. 1b). Socket buttress ridges high, short, straight, with reflexed ends (pl. 5, figs. $1 \mathrm{~b}, 2 b, 4 b$ ). Medial ridge relatively narrow, short, high, with deeply cleft anterior end (pl. 5 , figs. $2 b-d)$. Breviseptum long and faint. Paired transmuscle ridges low, abruptly bent (pl. 5 , figs. $1 b, d-e$ ). Internal surface of both valves finely papillose, margins finely striated.

Remarks.-These specimens from Kentucky differ from specimens from Minnesota by the somewhat discontinuous and hackly character of the costellae, by the irregular wrinkling of the surfaces of the valves, by the slightly greater convexity of the largest dorsal valve, and by the rhombic shape of the diductor muscle field of the largest ventral valve. The differences in costellae and the wrinkling of the valves may be preservational or environmental in origin. The greater convexity of the dorsal valve and the rhombic shape of the diductor muscle field may be the products of late ontogenetic change. I believe that these differences are not great enough to require the erection of a new species.

The identity of the specimen referred to $F$. scofield $i$ by Cooper (1956, pl. 265, C, fig. 5), is questionable. The similarity of the trans-muscle ridge system of this specimen to the trans-muscle ridges of Microtrypa noted by Williams $(1962$, p. 207$)$ is indeed correct. The bifid ends of the medial ridge of this specimen are much longer than those found in Furcitella, and the adjacent pairs of trans-muscle ridges lack the abrupt bend found in Furcitella and Holtedahlina (see pl. 7, figs. 10-13). Additionally, the central region and trans-muscle ridges of this valve are coarsely papillose, a trait that has not been observed in other specimens of Furcitella.
Occurrence, measurements, and specimens.-All specimens are from USGS loc. 5078-CO, Camp Nelson Limestone near High Bridge, Ky. Specimens include 8 ventral valves, 5 dorsal valves, 1 small articulated specimen, and fragments. The largest ventral valve, if complete, would measure about $19 \mathrm{~mm}$ wide $\times 15 \mathrm{~mm}$ long. A smaller complete ventral valve is $15^{1 / 2} \mathrm{~mm}$ wide $\times 12 \mathrm{~mm}$ long. The largest dorsal valve, incomplete, is $21^{1 / 2} \mathrm{~mm}$ wide. Figured specimens are numbered USNM 245327-245336.

Several specimens, numbered USNM 245369, from USGS loc. 5015-CO, Salvisa Bed of the Perryville Limestone Member of the Lexington Limestone near Perryville, Ky., superficially resemble $F$. cf. $F$. scofieldi. These specimens are steinkerns and eroded articulated valves preserved in coarse chalcedony (beekite) and consequently cannot be identified with certainty. Mixed with these are small resupinate articulated specimens referred to Strophomena s.s., numbered USNM 245370. These specimens bear traces of alternate costellae and fine, randomly arranged pseudopuncta which differentiate them from Tetraphalerella cf. T. costellata. These specimens are too poorly preserved to be identified.

\section{Subfamily STROPHOMENINAE King, 1846}

Genus TETRAPHALERELLA Wang, 1949

1949. Tetraphalerella Wang, Geol. Soc. America Mem. 42, p. 28-29. [pars] Strophomena, of authors.

Type species. -Tetraphalerella cooperi Wang, Geol. Soc. America Mem. 42, p. 29-30, original designation.

Diagnosis. - Shells generally large, semicircular to subrectangular, resupinate. Parvicostellae fine and uniform. Ventral interarea long, apsacline, forming sharply acute angle with external surface. Pseudodeltidium long, narrow, smoothly arched to depressed. Pseudopuncta coarse, arranged in rows. Teeth slender, pointed; dental plates thin, laterally flared. Dorsal surface of teeth not strongly depressed below extension of plane of interarea. Diductor muscle bounding ridge inclined. Cardinal process stout, myophores cupped. Sockets short, gaping. Trans-muscle ridges obscure to absent.

Remarks and comparisons. - Tetraphalerella is differentiated from Trigrammaria, Microtrypa, and Actinomena by the possession of fine uniform costellae and the lack of prominent trans-muscle ridges. Additionally, Tetraphalerella generally lacks the subtriangular folded shape of Trigrammaria, is larger than Microtrypa, and is more highly domed than Actinomena.

Tetraphalerella and Strophomena tend to be homeomorphic. Wang $(1949$, p. 29) was correct in com- 
menting that "Tetraphalerella embraces a large group of species that have been heretofore assigned to Strophomena on the basis of their convexo-concave profile and other similarities." In fact, the concept of Strophomena still understood by many authors is that of Tetraphalerella. Fortunately, these genera are not difficult to separate if well-preserved specimens, particularly internal surfaces, are inspected carefully. The most conspicuous differences between these genera are found in their ventral interareas, teeth, diductor muscle bounding ridges, cardinal processes, trans-muscle ridges and psesudopuncta. No single character alone, perhaps with the exception of the pseudopuncta, satisfactorily differentiates these genera.

Any discussion of Strophomena must ultimately depend upon the attributes of $S$. planumbona (Hall), which is presumed to be the type species. Hall and Clarke (1892, p. 245-252), Miller (1897), and Nickles (1903, p. 214-217) have provided detailed comments on the status of $S$. planumbona as type species of the genus. Succeeding authors have generally acknowledged $S$. planumbona as the type species.

Externally, Tetraphalerella and Strophomena are difficult to separate. A subtle difference is found in the ventral interarea, which in Tetraphalerella is generally relatively longer than that of Strophomena and makes a more acute angle with the surface of the ventral valve. That is, the ventral posterior margin of Tetraphalerella often seems unusually sharp. This condition is exceptional in Strophomena, although present in S. vetusta (James). The pseudodeltidium of Tetraphalerella is generally narrower (left to right) than that of Strophomena, and the margins of the delthyrium of some species seem somewhat convexly curved, giving the pseudodeltidium a sharply pointed appearance (pl. 4, figs. $3 b, 4 d)$. The pseudodeltidium of Tetraphalerella is generally arched, and in some species carinate (pl. 4, fig. $2 a$ ), but it may be flat, medially grooved, or even slightly concave.

The teeth of Tetraphalerella are unusual. The teeth of young and ephebic individuals, especially of stratigraphically older species, tend to be very slender. In some specimeris, these teeth are no more than thickened ridges along the dorsal margins of the dental plates (pl. 4 , fig. $2 a$; pl. 6 , fig. $1 c$ ). The anterior termination of a tooth is marked by a notch in the edge of the dental plate. In sorne well-preserved specimens, a short spine projects anteriad from the notch. The dorsal edges of the teeth are depressed only slightly below an imaginary extension of the plane of the interarea, perhaps because the dorsal valve of Tetraphalerella generally lacks a prominent posterio-lateral socket ridge. In gerontic specimens, especially of stratigraphically younger species such as $T$. neglecta (James) and $T$. cooperi Wang, the teeth are somewhat thicker. Additionally, the notch between the lateral edge of a tooth and the anterior edge of the palintrope may be filled with secondary shell matter to produce a tooth much like that of Rafinesquina. Commonly, the delicate teeth of immature specimens are missing because of fracture, and in gerontic specimens, the teeth may be dulled or obscured by deposits of secondary shell matter on their lateral and medial surfaces. The teeth of Tetraphalerella do not seem to be semidenticulate.

How these delicate teeth of Tetraphalerella afforded adequate articulatory contact or strength is difficult to understand, especially for large specimens of some species which may be as much as $6 \frac{1 / 2}{\mathrm{~cm}}$ wide and highly domed. Additionally, the delicacy of the tooth contrasts with the socket structure, which, although short, is generally stoutly constructed.

The teeth of Tetraphalerella are commonly difficult to discern in conventionally oriented photographs of the ventral interior, because the teeth may be almost as narrow as the dental plates and thus "lost" along the upper (dorsal) edges of the plates (contrast pl. 4 , figs. $2 a, \mathrm{~d}, 4 d$, e).

The teeth of Strophomena planumbona tend to be blocky, blunt, and wide in comparison with length. Their dorsal surfaces are depressed below the plane of the interarea and separated from the interarea by a transverse groove or a pocket to accommodate the posterio-lateral socket ridge. Well-preserved specimens bear many erratically shaped semidenticles. The dental plates of Strophomena recede, whereas those of Tetraphalerella, except for bearing a notch below the anterior termination of the tooth, blend into the muscle bounding ridge and thus seem to advance, as noted by Wang $(1949$, p. 29). The dental plates of Tetraphalerella tend to be somewhat thinner than those of Strophomena, but the dental plates of gerontic specimens of both genera are usually obscured by secondary deposits. Both genera may have a fold along the length of the dental plate to the apex of the delthyrial chamber (pl. 4, fig. $2 d$ ). This seems to mark the lateral margin of the adjustor muscle scar.

The muscle bounding ridges of both genera are so variable that generalization is difficult. The muscle bounding ridge of Strophomena tends to rise erectly from the floor of the valve, to be rather low, continuous, and wide (thick). The muscle bounding ridge of Tetraphalerella commonly seems to be pressed down against the surface of the valve; that is, the dorsal surface of the muscle bounding ridge lies at a low angle to the surface of the valve (pl. 7, figs. 3, 4,6). The continuity of the muscle bounding ridge around the anterior margin of the diductor muscle field and the strength of the medial ridge of the diductor muscle field are incon- 
sistent, ontogenetically related characteristics. The ventral palintrope of both Strophomena and Tetraphalerella may be supported by a ridge, especially in gerontic individuals. This is a widespread strophomenacean characteristic, not peculiar to Tetraphalerella, as Wang $(1949$, p. 29$)$ indicated.

Inside the dorsal valve, the cardinal-process lobes of Tetraphalerella are erect and have large, deeply cupped myophores facing posteriad (pl. 4, fig. 1b; pl. 7, fig. 8b). The cardinal-process lobes of Strophomena are lower, not so deeply cupped (except in some gerontic specimens) and have myophores that face more in the ventral direction than toward the posterior. The socket structures and chilidia of these genera are not strikingly different. The sockets of Tetraphalerella do not bear semidenticles, whereas the edges of the sockets of Strophomena may be prominently semidenticulate. Tetraphalerella has an inconspicuous medial ridge extending anteriad from the notothyrial platform (pl. 4, figs. $1 b, 5 b$; Wang, 1949 , pl. 8, fig. 4). Otherwise, transmuscle ridges in the dorsal valve are faint to absent. In Strophomena, juvenile specimens bear grooves where ridges will develop. Adult and gerontic specimens possess elaborate ridges, including a breviseptum, trans-muscle ridges and, in some species, adventitious ridges.

Finally, perhaps the most apparent difference between these genera is found in the pseudopuncta. The pseudopuncta of Tetraphalerella are coarse and widely spaced compared with those of Strophomena. Pope (1976, p. 206) has shown that Strophomena has about three times as many pseudopuncta per unit area of shell as has Tetraphalerella and that the diameter of the taleolae of Strophomena is about half the diameter of the taleolae of Tetraphalerella. Additionally, as Wang (1949, pl. 8, fig. 6) clearly showed, the pseudopuncta of Tetraphalerella are arranged in radial rows, whereas they are randomly distributed in Strophomena. Care must be exercised in observing the pseudopuncta. Either exfoliated or etched surfaces of the shell should be examined because interior surfaces of Strophomena may possess widely spaced endospines that do not truly reflect the densely packed pseudopuncta below the surface.

In summary, Tetraphalerella and Strophomena externally are homeomorphic. Their differences are of about the same nature and degree as those that separate Rafinesquina and Oepikina.

Another problem that cannot be solved at this time concerns the genus Tetraphalerella. In 1933, Bancroft erected the genus Longvillia based upon Orthis grandis J. de C Sowerby. Salmon (1942, p. 573) misdirected understanding of Longvillia (and misspelled the name, Longvilleia) by suggesting that some species of Rafines- quina of Cincinnatian age might belong to Longvillia. Williams (1963, p. 452) assigned Orthis grandis Sowerby to Strophomena, and in 1965 (p. H384) he placed Longvillia in synonymy with Strophomena.

Excellent molds attributed to Strophomena grandis from the "Wattsella unguis zone" of the Horderley District, East Shropshire, England, are in the collections of the U.S. National Museum (Natural History) under accession number 105890. Latex casts from these specimens conform in all major morphological features to Tetraphalerella. Rather coarse, crudely aligned papillae on the internal surfaces of the valves suggest the presence of coarse large pseudopuncta. If the shell matter of Strophomena grandis could be found and if this species is coarsely pseudopunctate, then Tetraphalerella must be regarded as a junior subjective synonym of Longvillia Bancroft, 1933, type species by original designation, Orthis grandis Sowerby.

\section{Tetraphalerella cf. T. costellata (Cooper)}

Plate 4, figures 2-6; plate 6, figures 1-2

1956. Strophomena costellata Cooper, Smithsonian Misc. Colln., v. 127, pts. 1-2, p. 933-934, pl. 255, A, figs. 1-19.

Diagnosis. - Shells small; outline semicircular, widest at hingeline, slightly alate; convexity low. Posterior region of dorsal valve with a shallow short sulcus; posterior region of ventral valve with a low short fold. Pseudodeltidium arched, slightly carinate. Parvicostellae very fine, very uniform.

Description.-Shells small. Outline semicircular to slightly subrectangular or subtriangular; slightly alate, greatest width at hingeline. Anterior margin uniformly rounded; lateral margins slightly convergent; posterior margin pointed (pl. 4, figs. $3 c, 4 b$ ). Convexity low, posterior regions of both valves almost planate, greatest curvature near anterior margin. Posterior region of dorsal valve with a short shallow sulcus; posterior region of ventral valve with a short low fold (pl. 4, fig. 3). Dorsal interarea short; ventral interarea long, set at a sharply acute angle to external surface. Cardinal extremities bent in dorsal direction (pl. 4, fig. 3d). Pseudodeltidium long, narrow, subcarinate (pl. 4, figs. $2 a, 3 d$ ). Foramen minute, round, apical.

Parvicostellae very fine, numbering 26 to 34 per 5 $\mathrm{mm}$; uniform in height or regularly alternating (pl. 4, figs. $4 f, 5 c$ ). Varices very fine, sharply delineated.

Teeth very narrow, located on dorsal edge of dental plates (pl. 4, figs. $2 a 4 d$; pl. 6, fig. 1c). Dental plates merge into low inclined muscle-bounding ridges (pl. 4, figs. $2 b, 4 e$ ). Dental plates slightly folded, fold extending to apex of delthyrial cavity (pl. 4, figs. $2 a-d, 4 d-e$ ). Anterior margin of diductor muscle scar obscure. Interior of dorsal valve smooth, lacking prominent ridges 
or septa (pl. 4, fig. 5b). Small sharp endospines in ventral valve, aligned radially in paired rows.

Remarks. - This species is distinguished from all other species of Tetraphalerella (and Strophomena) by its low convexity, knife-sharp posterior edge on ventral valve, pointed posterior margin, low sulcus in the dorsal umbo and fold in the ventral umbo and by its exceedingly fine uniform costellae. Additionally, the rows of endospines are paired, a feature not observed in all species of Tetraphalerella.

These specimens from Kentucky are probably juvenile, which accounts for the incomplete musclebounding ridges, (compare pl. 4, fig. $4 \mathrm{~d}$, with Cooper, 1956, pl. 255, fig. 11), obscure muscle scars, and thin dental plates. The lateral-anterior edges of the valves, which in topotypic specimens of T. costellata from the Bromide Formation of Oklahoma are ventrally flexed, are chipped, causing the valves to appear more subtriangular in shape than they may have been originally (pl. 4, figs. 3, 4). Finally, these specimens from Kentucky have a greater number of costellae per $5 \mathrm{~mm}$ along the anterior margin (26-34) than have topotypic specimens of $T$. costellata (Cooper), which have 17-20 costellae per $5 \mathrm{~mm}$.

$T$. cf. T. costellata resembles Strophomena platyumbonata Cooper (1956, pl. 254, C) from the Carters Limestone of Alabama in ornament and outline. $S$. platyumbonata, however, is conspicuously alate and has a rather narrow diductor muscle field. S. platyumbonata is a reasonable alternative identification for these specimens from Kentucky.

Measurements. - Largest ventral valve, $18 \mathrm{~mm}$ wide $\times$ $15 \mathrm{~mm}$ long. Other ventral valves, $14 \mathrm{~mm}$ wide $\times 11 \mathrm{~mm}$ long; $13^{1 / 4} \mathrm{~mm}$ wide $\times 11 \mathrm{~mm}$ long.

Specimens and occurrence. - All studied specimens are composed of fine-grained dense silica. They include 5 ventral valves, 1 incomplete dorsal valve, 1 fine articulated specimen, and several fragments. Specimens are from USGS loc. 5078-CO, Camp Nelson Limestone near High Bridge, Ky. Figured specimens are numbered USNM 245320-245326. Fragments resembling $T$. cf. $T$. costellata occur unsilicified in limestone recollected (by Miami University) from 7875-CO, Camp Nelson Limestone near High Bridge, Ky.

\section{Tetraphalerella cf. T. musculosa (Fenton) \\ Plate 7, figures 1-9}

1928. Strophomena musculosa Fenton, Am. Midland Naturalist, v. 11, nos. 3, 4, p. 158-154, pl. 8, figs. 1-7.

1956. S. musculosa Cooper, Smithsonian Misc. Colln., v. 127, pt. 1, p. 942.

Diagnosis. - Shells large; outline semicircular, subrectangular, or subtriangular, obscurely nasute; alate. Dorsal valve strongly convex. Parvicostellate, alternation irregular. Cardinal extremities deeply and coarsely rugose. Diductor muscle field wide, flabellate, radially ridged; muscle-bounding ridge scalloped. Cardinalia small relative to size of valve.

Description. - Valves large; outline long and subrectangular in small specimens to subrectangular, subtriangular, or transversely semicircular in large specimens (pl. 7, figs. 2, 3, 9a). Cardinal extremities slightly rounded to alate (pl. 7, fig. 5; Fenton, 1928, pl. 8, fig. 1), and dorsally flexed (pl. 7, fig. 9b). Anterior margin slightly nasute (pl. 7, figs. $3,9 a$ ). Valves strongly convexo-concave; umbos planate, greatest curvature just behind midvalve. Ventral interarea long, flat; dorsal interarea very short; pseudodeltidium arched and slightly carinate (pl. 7, fig. 4).

Parvicostellae coarse, irregularly alternating, with 2-4 small costellae between larger costellae. Costellae number 11 per $5 \mathrm{~mm}$ at anterior margin of dorsal valve. Cardinal extremities of dorsal valve deeply rugose (pl. 7, fig. 1, left side; Fenton, 1928, pl. 8, figs. 6-7); posterior margin of ventral valve weakly rugose.

Teeth narrow ridges along dorsal edges of dental plates (pl. 7, figs. 4, 7). Dental plates laterally flared, merge into muscle-bounding ridges. Diductor muscle scar large, broadly flabellate, radially ridged (pl. 7, figs. $3,4,7$ ). Muscle-bounding ridge weak (pl. 7, fig. 5) to high and thick (pl. 7, figs. 3, 4), with anterior-medial emargination. Outer edge of muscle-bounding ridge scalloped (Fenton, 1928, pl. 8, figs. 1, 2). Adductor muscle scar oval, slightly elevated (pl. 7, fig. 3). Marginal rim of ventral valve deeply grooved (Fenton, 1928, pl. 8, fig. 1). Cardinalia small relative to size of valve. Cardinal process lobes tall, erect, deeply cupped (pl. 7, fig. 8b); socket buttress ridges delicate, low, recurved (pl. 7, fig. $8 a$; Fenton, 1928, pl. 8, fig. 5). Medial ridge low, broad; trans-muscle septa obscure (Fenton, 1928, pl. 8, fig. 5). Endospines coarse, radially arranged in paired rows.

Remarks. - These specimens are poorly preserved in friable saccharoidal silica, beekite (chalcedony), or fragile, dense silica with crystalline overgrowths. The thin margins of these shells and fine surface details are largely lacking, so the descriptions of costellae and outline shape are tentative. Referral of these specimens to $T$. musculosa is provisional but is the most appropriate assignment, considering the large size and considerable inflation of the valves, the large diductor muscle field, and the deeply wrinkled cardinal extremities of the largest dorsal valve.

Measurements and occurrence.-Total sample, 17 specimens, most incomplete. The largest dorsal valve measures $36 \mathrm{~mm}$ wide $\times 30^{1 / 2} \mathrm{~mm}$ long $\times 14^{1 / 2} \mathrm{~mm}$ high; a smaller dorsal valve measures $28 \mathrm{~mm}$ wide $\times 23 \mathrm{~mm}$ long. The largest ventral valve measures $33 \mathrm{~mm}$ wide $\times$ approximately $29 \mathrm{~mm}$ long. Other ventral valves are: 34 
$\mathrm{mm}$ wide $\times 29 \mathrm{~mm}$ long; $22^{1 / 2} \mathrm{~mm}$ wide $\times 19 \frac{1}{2} \mathrm{~mm}$ long; and $181 / 2 \mathrm{~mm}$ wide $\times 16 \mathrm{~mm}$ long. Judging from the size of the muscle-bounding ridge of incomplete specimens, the maximum size should exceed the largest measured ventral valve by about 18 percent; that is, it should be about $44 \mathrm{~mm}$ wide.

Figured specimens are from USGS loc. 7784-CO, Curdsville Limestone Member, Lexington Limestone, near the crossing of U.S. Route 27 and the Kentucky River. Other fragmentary specimens are from locs. 5083-CO, Curdsville Limestone Member of Lexington Limestone, near Blackburn Memorial Bridge on U.S. Route 62 over the Kentucky River; 7782-CO, same general location; and 7785-CO, Curdsville Limestone Member of Lexington Limestone, near U.S. Route 27 bridge over the Kentucky River.

\section{Tetraphalerella sp.}

Plate 4, figure 1

Description. - Shell medium size; outline semicircular. Profile strongly convex, somewhat geniculate; almost planate in posterior third of valve, greatest curvature near midvalve. Ornament finely parvicostellate, distinctly alternate. Cardinalia strong; medial ridge narrow and low; trans-muscle septa obscure.

Discussion. - A unique complete dorsal valve unquestionably belonging to Tetraphalerella was found among specimens of $T$. cf. T. costellata and Furcitella cf. $F$. scofieldi from USGS loc. 5078-CO. This specimen is larger, more convex, and has more strongly alternating ornament than do $T$. costellata or $T$. platyumbonata (Cooper). The valve most closely resembles T. auburnensis nasuta (Cooper), which Cooper (1956, p. 106) reported from the Tyrone Limestone of Kentucky. The valve, however, is more convex than T. auburnensis nasuta and is not nasute. The valve is smaller, more finely costellate, and has relatively stronger cardinalia than does T. musculosa.

Measurements. $-21^{1 / 2} \mathrm{~mm}$ wide, $16^{1 / 2} \mathrm{~mm}$ long, $6 \frac{1 / 2}{2}$ $\mathrm{mm}$ high. Costellae number $17-20$ per $5 \mathrm{~mm}$ along anterior margin, with 2-4 smaller costellae per bundle.

Occurrence.-One complete, densely silicified dorsal valve from USGS loc. 5078-CO, Camp Nelson Limestone, near High Bridge, Ky. USNM number 245319. Another coarsely silicified, incomplete, and unidentifiable specimen assigned to Tetraphalerella comes from USGS loc. 4964-CO, Grier Limestone Member, Lexington Limestone, near Frankfort, Ky.

Family LEPTAENIDAE Hall and Clarke, 1894 Subfamily LEPTAENINAE Hall and Clarke, 1894

Genus LEPTAENA Dalman, 1828

1828. Leptaena Dalman, Svenska Vetensk. Akad. Handl., 1827, p. 93. 1957. Leptaena, Spjeldnaes, Norsk Geol. Tidsskrift, v. 37, p. 171-174.
1967. Leptaena, Kelly, Palaeontology, v. 10, pt. 4, p. 590-594.

1968. Leptaena, Cocks, British Mus. (Nat. History) Bull., v. 15, no. 6, p. 299-302.

Type species. -Leptaena rugosa Dalman, 1828; subsequent designation of King, 1846, p. 28.

Diagnosis. - Shells transversely subrectangular to semielliptical; cardinal angles acute to alate. Profile with sharp dorsal geniculation; generally with narrow ridge on ventral valve along line of geniculation. Costellae uniform, crossed by prominent concentric rugae. Pseudodeltidium reduced; chilidium prominent; foramen open. Pseudopuncta coarse. Teeth strong, blunt; dental plates receding. Diductor muscle scar oval, impressed, with low muscle-bounding ridge. Cardinal process lobes tabulate. Notothyrial platform anchorshaped; medial ridge low, breviseptum narrow; transmuscle ridges obscure.

Remarks. - The synonymy of Leptaena shown above is necessarily abbreviated. It cites only the original description of this well-known genus, plus three contemporary studies in which additional information and references may be obtained.

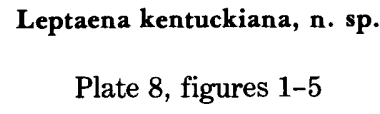

Diagnosis.-Large, thin-shelled leptaenid with free margin uniformly rounded. Cardinal angles orthogonal to alate. Geniculation at about $15 \mathrm{~mm}$ from beak, not preceded by a prominent depression or ridge. Costellae coarse and wavering; rugae discontinuous, moderate in number and height. Diductor muscle scar not bordered by a ridge.

Description.-Valves large, thin shelled. Outline transversely semielliptical, with slight truncation along anterio-central margin (pl. 8, fig. 4a). Cardinal extremities orthogonal (pl. 8, fig. 4a) to slightly alate. Ventral umbonal region gently convex (pl. 8, figs. $2 a, 4 c$ ); central region of valve flat, undulating. Geniculation of ventral valve at $15 \mathrm{~mm}$ from beak, not preceded by prominent depression or ridge. Dorsal valve planate from beak to geniculation. Trail short, nonrugose, very thin; set at $55^{\circ}$ to surface of valve. Hingeline gently curved in posterior view.

Costellae of disc coarse, wavering; separated by deep interspaces (pl. 8, fig. 1b). Costellae of variable width, widest at crests of rugae (pl. 8, fig. 3b), increasing in width toward margin of valve. Costellae number about 9 per $5 \mathrm{~mm}$ in the lateral sectors of the valve, 10-14 per 5 $\mathrm{mm}$ in the anterio-central region. Costellae on trail low, fine, uniform in width. Protegular region not costellate (pl. 8, fig. 3b). Intercalation of costellae more common than bifurcation. Rugae moderately prominent, discontinuous, numbering 3-5 per $5 \mathrm{~mm}$ toward margin of disc. 
Umbonal regions obscurely rugose. Valves irregularly deformed, possessing growth interruptions.

Interareas long, flat, striated (pl. 8, figs. 1c, 4e). Pseudodeltidium short, highly arched (pl. 8, figs. $2 c, d$ ). Foramen round, mesothyrid.

Teeth large, blunt; dental plates receding, laterally flared (pl. 8, figs. $4 d, e$ ). Diductor muscle scar oval, impressed into shell, not surrounded by ridge (pl. 8, figs. $4 d, 4 e$ ). Adductor muscle scar and track narrow (pl. 8 , fig. 4d). Narrow adjustor muscle scar at base of dental plates. Interior of ventral valve corrugated by rugae, striated by costella.e (pl. 8, figs. $1 c, 4 b$ ). Endospines coarse and regularly positioned (pl. 8 , figs. $3 c, e$ ).

Ontogeny. - The smaller figured specimens of L. kentuckiana are assumed to be juveniles of the single large ventral valve, the holotype; they are from the same collection. If this is true, the species shows some ontogenetic change in outline shape, profile, ornament, and diductor muscle scar. The outline shape of the juvenile valves is more transverse and alate (pl. 8, figs. $1 b-3 b)$ than that of the adult valve. The convexity of the juvenile ventral valves is greater (pl. 8 , figs. $1 b, 2 a$ ) than that of the disc of the adult valve. Costellae increase in width to the margin of the juvenile valves, whereas this trend is reversed in the anterio-central region and on the trail of the adult valve. Rugae are more prominent on the adult valve. Juvenile ventral valves show only a faint outline of the diductor muscle scar which in the adult shell is deeply impressed.

The dorsal valve of $L$. kentuckiana is known only from juvenile specimens. The juvenile dorsal valve is broadly transverse, alate, and planate to slightly concave (pl. 8, figs. $3 b-c, 5 a-b$ ). Rugae are weaker but more continuous than those of the ventral valve. The cardinal process lobes are divergent vertical blades; the sockets are short and shallow (pl. 8 , figs. $3 c-e$ ). The chilidium is folded into the cleft between the cardinal process lobes (pl. 8, fig. 3e).

Comparison of species. $-L$. kentuckiana is distinct from all other known species of Leptaena from the Ordovician of North America by the combination of its size, shape, beak-to-geniculation distance, and ornament. $L$. kentuckiana most closely resembles $L$. ordovicica Cooper and L. richmondensis precursor Foerste. L. ordovicica, figured by Cooper (1956, pls. 208, 212, 228), has discontinuous rugae and, in some specimens from Linville Station, Va., has oval diductor muscle scars that lack bounding ridges. $L$. ordovicica, however, differs from $L$. kentuckiana by being smaller, more transverse in outline, more finely costellate, and by being much shorter from the beak to the initiation of geniculation. Additionally, many specimens of $L$. ordovicica have a prominently elevated rim posterior to the geniculation. L. richmondensis precursor Foerste resembles L. ken- tuckiana in possessing somewhat discontinuous low rugae and in lacking a depression or rim bordering the geniculation. L. richmondensis precursor, however, is rather small, possesses a long trail, and initiates geniculation at about $8 \mathrm{~mm}$ anterior to the beak.

Leptaena richmondensis richmondensis Foerste differs from $L$. kentuckiana by having much stronger and more continuous rugae, a longer trail bordered by a rim, generally a slight anterior emargination and alation of the cardinal extremities, and a shorter beak-togeniculation distance. L. tenuistriata(?) Sowerby, as figured by Foerste $(1910$, p. $45-46$, pl. 5 , fig. $9 a-b)$, is smaller and more transverse than L. kentuckiana and does not bear as many rugae. Both $L$. gibbosa (James) and L. gibbosa invenusta Foerste are too finely costellate and too faintly rugose to be conspecific with L. kentuckiana. L. moniquensis Foerste (1924, p. 116-117, pl. 14, figs. 2-3) has distinctly alternate ornament. $L$. kentuckiana cannot be identified as $L$. reticulata (Shaler), figured by Twenhofel (1927, pl. 22, fig. 19), because the rugae of the latter species are too numerous and anastomosing, and its geniculation is poorly defined.

Among Ordovician species of Leptaena described or redefined in western Europe, L. kentuckiana bears greatest resemblance to $L$. salopiensis Williams (1963) from the Actonian Stage of the Bala District, Merionethshire, Wales. This European species, however, is slightly larger and more transverse than $L$. kentuckiana yet has a shorter beak-to-geniculation dimension. Additionally, the diductor muscle scar of $L$. salopiensis is bordered by a modest ridge. L. rugosa Dalman, type species, differs conspicuously from $L$. kentuckiana by the possesion of strong continuous rugae, a high rim marginal to the geniculation, and a long trail.

$L$. kentuckiana is not assigned to the genus Kiaeromena Spjeldnaes because of its abrupt geniculation, closely spaced rugae, and distinctly leptaenid juvenile dorsal valve.

Measurements. - USNM 245367, adult ventral valve: length $16.6 \mathrm{~mm}$; width $23.5 \mathrm{~mm}$; distance from beak to initiation of geniculation, $15.3 \mathrm{~mm}$; approximate greatest height above plane of commissure, $4 \mathrm{~mm}$.

Occurrence, specimens, and types.-USGS loc. 5136-CO, Upper Ordovician, Reba Member, Ashlock Formation, Clara Wilham quarry, Dunnville, Ky. The collection contains 10 specimens, consisting of 1 adult ventral valve and 9 juveniles. The juvenile specimens include two well-preserved ventral valves and two wellpreserved dorsal valves; the others are poorly preserved or fragmentary. The adult ventral valve shown on pl. 8 , fig. 4, is designated the holotype; it is USNM 245367. The four well-preserved juvenile valves shown on pl. 8 , 
figs. 1-3, 5, are assigned USNM numbers 245363 to 245366 .

\section{Subfamily MURINELLINAE Pope, 1976}

Genus MURINELLA Cooper, 1956

1956. Murinella Cooper, Smithsonian Misc. Colln., v. 127, p. 844-845.

Type species.-Murinella partita Cooper, 1956, p. 847-848, original designation.

Diagnosis. - Outline subrectangular to semielliptical; profile biconvex to weakly concavo-convex. Parvicostellate, with major growth interruptions or comae common. Pseudodeltidium large, arched; foramen open. Teeth strong, blunt; dental plates short, widely flared, not advancing. Diductor muscle field oval, divided by medial ridge; muscle-bounding ridge low. Cardinal process lobes short, stout; myophores cupped. Socket buttress ridges thick. Dorsal medial ridge short, broad; trans-muscle ridges short, strongly bent; breviseptum long. Interior of dorsal valve with prominent marginal flange.

\section{Murinella? sp. \\ Plate 5, figure 7}

Description. - Known from one, incomplete, coarsely silicified dorsal valve. Valve subrectangular, wider than long, with rounded cardinal angles. Profile of valve gently sigmoidal; convex toward posterior, planate in central region, concave toward anterior, with a reflexed and thickened marginal rim. Radial ornament obscure. Chilidium poorly preserved; continuous around posterior ends of cardinal process lobes; merges into thin sharp ridge marginal to socket.

Cardinal process lobes stout, low, wider than long; myophores cupped, facing toward posterior, wider than shafts. Meso-cardinal ridge thin; posterior edge fused to chilidium. Sockets shallow; socket buttress ridges widely divergent and thick. Posterior margin of socket defined by an accessory ridge. Medial ridge wide, low, short, and unbranched; flanked by two pairs of indistinct low broad ridges or swellings in the adductor-musclefield region. Concentric rim thick, relatively high; corresponds to the reflexed margin of exterior, producing greatly thickened anterior and lateral margin on valve.

Discussion and comparison.-Unfortunately, this curiously shaped brachiopod is known from only one incomplete coarsely silicified valve. The silicification consists of rather coarse, weakly joined, "beekite" beads, which have not preserved details of external ornament, the internal surface texture of the valve, or, if originally present, the thin anterior and lateral margins of the valve.

The specimen was part of a collection that contained many incomplete valves and fragments of Oepikina minnesotensis (Winchell). Although about the same size as the specimens of Oepikina and as coarsely silicified, Murinella? sp. is readily distinguished from Oepikina by its plan-shape profile, the external ridge around the anterior margin, the large, wide, but short cardinalprocess lobes and the long, widely divergent socket buttress ridges. The specimen superficially resembles Oepikina lirata Cooper in plan shape but is readily separated from that species by the above-mentioned features.

The general shape of this brachiopod superficially suggests relationship to species of Hesperinia, Dactylogonia, Cyphomena, Bellimurina, and Limbimurina (minus the trail). Relationship to all these genera is doubtful because of the larger cardinal-process lobes and the longer recurved socket buttress ridges of this specimen. Additionally, this specimen lacks the prominent paired lateral septa possessed by Dactylogonia and Cyphomena, the acute cardinal angles of Cyphomena, the distinctive ornament of Bellimurina and Limbimurina, and the elaborate trail of Limbimurina; also it is considerably younger than Hesperinia.

The most prominent and unusual feature of this specimen, its marginal rim, as well as other structures, suggests relationship to Murinella Cooper, especially to Murinella muralis Cooper (1956, p. 846-847, pl. 226, D, figs. 10-28). The specimen from Kentucky compares favorably in shape with the specimen of $M$. muralis shown by Cooper (1956) on his plate 226, fig. 25, and in size with the specimens shown in his figures 14, 15, 21, and 22. The socket buttress ridges resemble those shown in Cooper's figure 19, and the cardinal-process lobes and wide medial ridge resemble those borne by the specimens of his figures 27 and 23. Murinella muralis has somewhat more pronounced paired lateral septa than does this specimen and a much higher marginal rim. The presence of a marginal rim at all on the new specimen is cause for suspecting a relationship with Murinella. Moreover, Murinella muralis from the Wardell Formation of Cooper and Pronty (1943) of Tennessee is compatible in age with this specimen from the Camp Nelson Limestone of Kentucky.

Measurements. - Measurements have been taken from accurately calibrated photographs because the specimen is too delicate to withstand calipers. Length, $11.7 \mathrm{~mm}$; width, $16 \mathrm{~mm}$; greatest thickness, at anterior margin, $2.8 \mathrm{~mm}$.

Occurrence.-USGS loc. 7875-CO, Camp Nelson Limestone; High Bridge, Ky. USNM 245337.

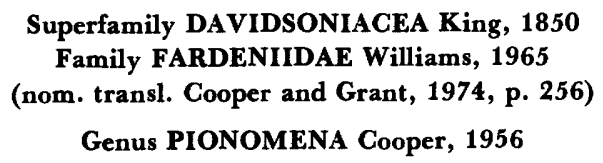

1956. Pionomena Cooper, Smithsonian Misc. Colln., v. 127, pt. 1, p. 901. 
Type species. - Pionomena neumani Cooper, 1956, p. 901, 902-903, original designation.

Diagnosis. - Shells small, semicircular, unequally biconvex; cardinal extremities orthogonal to rounded. Ornament multicostellate to weakly fascicostellate. Pseudodeltidium short, arched; foramen open, small, apical; chilidium complete to bilobed. Impunctate. Teeth moderately strong, pointed; dental plates short to slightly advancing. Cardinal process lobes minute, beadlike, closely spaced. Dentifers triangular, fixed to valve along posterior margin, not fused to floor of valve. Notothyrial platform obscure; medial ridge broad, very low.

Remarks. - Cooper (1956), Williams (1965), and Pope (1976) assigned Pionomena to the Superfamily Strophomenacea. The presence of perideltidial areas on $P$. recens, as well as the impunctate shell matter and shape of the cardinalia, require reassignment of Pionomena to the Iavidsoniacea. The triangular suspended dentifers of Pionomena resemble those of Gacella Williams. In contrast, the sockets of Fardenia Lamont and Coolinia Bancroft are excavated into the shell and are bordered by a rodlike brachiophore. Pionomena is retained here provisionally within the Fardeniidae pending comprehensive restudy of the early davidsoniacearis. The structure of the socket may provide a means for subdividing the family.

\section{Pionomena recens Neuman, 1967}

Plate 7, figures 16-31; text-figure 12

1967. Pionomena recens Neuman, U.S. Geol. Survey, Prof. Paper 583-A, p. A12-A.13, pl. 2, figs. 21-36.

Diagnosis. - Multicostellate. Pseudodeltidium uniformly arched, not cerrinate. Ventral valve smoothly convex, not folded. Dental plates short; diductor muscle scar not bordered by long thin plates.

Morphological addendum and remarks. - The detailed description of this species by Neuman (1967, p. A12-A13) does not need to be restated here. Some additional morphological attributes of $P$. recens, however, need to be described and considered.

Some specimens of $P$. recens possess a faint but unmistakable perideltidial area (pl. 7, figs. $20 b$ (scanning electron microscope (SEM) photograph), 20c, 21 $b, 22 b$, 26b; Neuman, 1967, pl. 2, fig. 28). Strangely, not every ventral valve bears a distinct perideltidium, the ratio being about one valve in six that does so.

The perideltidium consists of a triangular region on each side of the ventral interarea immediately lateral to the pseudodeltidium or lateral to the trace of the tooth along the margin of the pseudodeltidium. The surface of the perideltidium of $P$. recens is elevated above the surface of the interarea and is flatter than the surface of the interarea, which is gently curved along an axis parallel to the hingeline. The thin sheet of shell material that forms the perideltidium seems, after SEM observation, to have originally extended from the lateral margin of the pseudodeltidium. On some specimens, subsequent erosion or nonpreservation has permitted the trace of the tooth adjacent to the pseudodeltidium to show through the perideltidium (pl. 7, fig. 20c, left side of photograph). The surface of the perideltidium bears weak striae (pl. 7, fig. 20b) approximately parallel to the hingeline. These striae are set at a slight angle to striae of the interarea and are somewhat more widely spaced than are those of the interarea. Transverse striae of the perideltidium, thus, have not simply been pressed up through the thin perideltidial sheet from the interarea beneath. The perideltidia of two specimens bear still fainter, more closely spaced, sagittal striae, not illustrated. These are on eroded areas and seem to reflect structures below the surface of the perideltidium. Unfortunately, a distinct perideltidium is not evident on the interarea of $P$. neumani, type species of Pionomena, shown by Cooper (1956, pl. 265, fig. 8); what appears to be a perideltidium is in fact a collapsed section of the interarea.

A small node or rod occurs on some dorsal valves immediately anterior to and below the cleft between the cardinal-process lobes (pl. 7, fig. 24b, 28b, 29b, 30, 31). This medial node is on only about one out of seven dorsal valves studied. The medial node varies considerably in form, from a short angular spine to a rounded bead to a rod. The medial node of one specimen (pl. 7, fig. 24a, $b$ ) is drawn out into a spike that extends almost as far to the anterior as the anterior ends of the dentifers. Careful examination of the base of this spike in the SEM shows that the process is firmly welded into the shell matter, confluent with the shell, and has the same surface texture and apparent porosity as the shell; that is, the spike is probably not a foreign fossil fragment lodged between the cardinal-process lobes.

The medial node is rarely symmetrical with respect to the cardinal-process lobes but generally is set slightly to the right of the plane of symmetry. This is not surprising because asymmetry of the cardinal-process lobes is observed sporadically throughout the Strophomenida. Where asymmetry is evident, it is generally the right lobe that departs in shape from the norm. This deformation perhaps resulted from some asymmetry of the soft tissues in that part of the animal.

The medial node is of unknown function. Although a medial node is not found on all species of davidsoniaceans (sensu Williams, 1965), its occurrence is sufficiently widespread, that to find it so infrequently noted is surprising. For example, a medial node is present on some but not all specimens of Coolinia subplana (Con$\mathrm{rad}$ ), as shown on plate 7, figures 14-15. It has been shown to occur on Tapajotia tapajotensis Dresser (1954, 
pl. 4, fig. 8); on Iridistrophia umbella (Barrande), by Havlícek (1967, p. 194, pl. 41, figs. 11-12); on Derbyia deercreekensis and Derbyoides nebrascensis, by Dunbar and Condra (1932, pl. 6, fig. 3 and pl. 14, figs. 3-4); and on species of Derbyoides, Hypopsia, and Goniarina, by Cooper and Grant (1974, pls. 26, 31, 34, 41 and 43). The widespread occurrence of this structure suggests that it is not an accidental or pathological deformity of the cardinalia. Additionally, the absence of a medial node from the Strophomenacea (s.s.) and its occurrence in species of the Davidsoniacea and Orthotetidina (sensu Cooper and Grant, 1974) supports the concept of the close relationship of the last two groups.

With regard to the description of $P$. recens by Neuman, it must be made clear that the dorsal "cardinal apparatus," specifically, the dentifers in the descriptive terminology of Cooper and Grant (1974, p. 258), is suspended above the internal surface ("shell floor") of the valve. The dentifers are attached to the shell only along their posterior margins. The junction beneath the dentifers is smoothed and perhaps reinforced by a fillet of secondary shell matter in larger specimens but is rather angular in some thin-shelled juveniles. The dentifers of $P$. recens, thus, differ distinctly from the rodlike "brachiophores" of Fardenia and Coolinia, which are united to the floor of the valve by a thin vertical partition. The cardinalia of two specimens of Coolinia subplana (Conrad) are shown on plate 7, figures 14-15, for comparison. The "brachiophores" on the right side of each specimen are complete, but the left "brachiophores" of both specimens are broken, revealing the thin supporting partition. If this vertical partition were rotated approximately $90^{\circ}$ so as to bridge the gap between the lower surface of the "brachiophore" and the posterior margin of the shell, a structure much like the dentifer of Pionomena would be formed.

Pionomena recens does indeed seem to be impunctate. Several dozen specimens examined optically and in the SEM fail to show pores, papillae, or endospines that might indicate the presence of puncta or pseudopuncta. My assignment of Pionomena to the Family Rafinesquinidae (Pope, 1976, p. 151) was based upon the association of a fragment of shell bearing endospines with specimens of $P$. neumani, an association that now is clearly spurious.

Comparison of species. - In addition to the differences between $P$. neumani Cooper and $P$. recens noted by Neuman (1967, p. A13) there are differences in the form of the pseudodeltidia and dental plates of these species.
The pseudodeltidium of $P$. recens is smoothly arched, whereas that of $P$. neumani is longer, narrower, and somewhat carinate along its midline. The dental plates of $P$. neumani extend somewhat farther to the anterior than those of $P$. recens, which although hidden beneath the teeth, cannot be described as receding or obsolescent, contrary to the diagnosis by Williams (1965, p. H388).

Specimens attributed to Strophomena billingsi Winchell and Schuchert and S. emaciata Winchell and Schuchert (nos. 6-6196, 6-6272, and 6116 in the collections of the University of Iowa, both species from the Decorah Shale of Iowa) bear a resemblance to $P$. recens. Both species from Iowa possess unmistakable perideltidial areas and seem to lack pseudopuncta. Both species may be referred provisionally to Pionomena, but this assignment cannot be determined with certainty until suitable internal views are available.

Measurements, specimens, and occurrence.-Figure 12 is only an approximation of the length-width relationship of the dorsal valves of $P$. recens. The collections contain so few complete and unbroken valves, that valves having ragged margins that could be completed with reasonable assurance by a thin line also were measured. Valves missing a cardinal extremity were measured from one lateral extremity to the midline, and the total width was obtained by doubling the number.

Numbers of complete specimens and identifiable fragments are as follows:

\begin{tabular}{cccc}
\hline USGS loc. & Ventral valves & Dorsal valves & Articulated valves \\
\hline 4879-CO & 1 & 1 & 0 \\
$4880-$ CO & 14 & 23 & 0 \\
$5015-$ CO & 87 & 189 & 26 \\
$5016-$ CO & 1 & 2 & 0 \\
\hline
\end{tabular}

The larger number of dorsal valves present in these collections does not indicate current sorting because many minute specimens are included. Rather, the smaller number of ventral valves reflects their very fragile character. Apparently the valves were easily disarticulated; most of the articulated specimens show some displacement of the valves.

Specimens illustrated herein bear USNM numbers 245347 to 245362 .

USGS locs. 4879-CO and 4880-CO are in the Grier Limestone Member of the Lexington Limestone, Jessamine County, Ky. Locs. 5015-CO and 5016-CO are in the Salvisa Bed, Perryville Limestone Member, Lexington Limestone, near Perryville, Ky. 


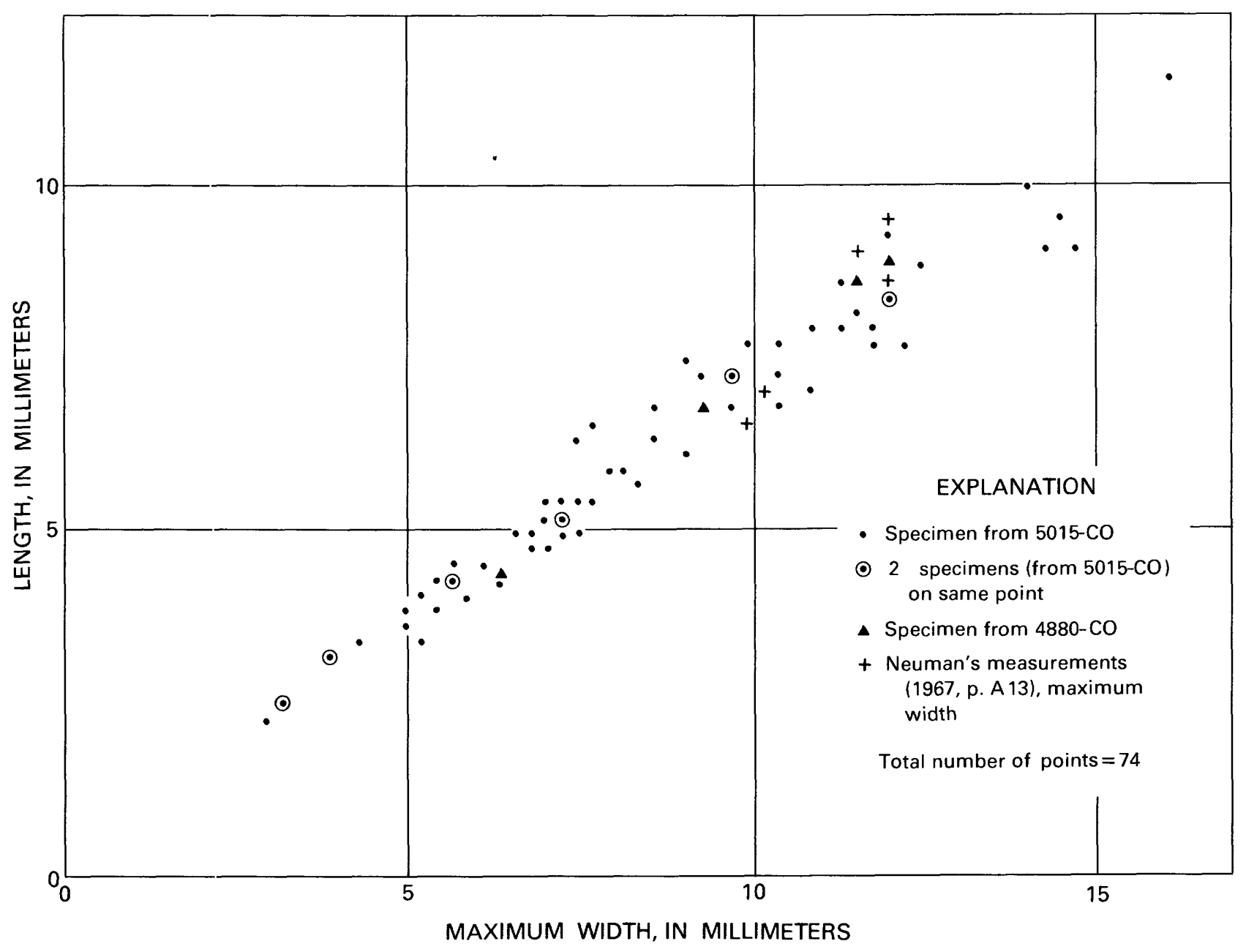

Figure 12. - Scattergram of the length vs. maximum width of dorsal valves of Pionomena recens Neuman. The columns and tiers of points do not lie along whole-millimeter increments because specimens were measured optically magnified $\times 4.4375$, and these data were used to construct the diagram. Points representing some of Neuman's (1967, p. A13) published measurements are high in the plexus of points because they are from ventral valves and consequently include the additional length of the ventral beak.

\section{REFERENCES CITED}

Alexander, R. R., 1975, Phenotypic lability of the brachiopod Rafinesquina alternata (Ordovician) and its correlation with the sedimentologic regime: Journal of Paleontology, v. 49, no. 4, p. 607-618, 2 pls.

Bancroft, B. B., 1933, Correlation tables of the stages CostonianOnnian in England and Wales: Gloucestershire, England, Nibley House, Blakeney, 4 p., 3 charts (private pub.).

Bretsky, P. W., and Bretsiky, S. S., 1975, Phenetic variation in some middle Ordovician strophomenid brachiopods: Geological Society of America Memoir 142, p. 3-36, 4 pls.

Cocks, L. R. M., 1968, Some strophomenacean brachiopods from the British lower Silurian: British Museum (Natural History) Bulletin, Geology, v. 15 , no. 6 , j. 283-324, 14 pls.
Cooper, B. N., and Prouty, C. E., 1943, Stratigraphy of the lower Middle Ordovician of Tazewell County, Virginia: Geological Society of America Bulletin, v. 54 , no. 6 , p. $819-886$.

Cooper, G. A., 1956, Chazyan and related brachiopods: Smithsonian Miscellaneous Collections, v. 127, pt. 1 (text), p. 1-1024; pt. 2 (plates), p. 1025-1245, 269 pls.

Cooper, G. A., and Grant, R. E., 1974, Permian brachiopods of West Texas, II: Smithsonian Contributions to Paleobiology, No. 15, 793 p., 191 pls.

Dalman, J. W., 1828, Uppställning och Beskrivning af de i Sverige funne Terebratuliter: Svenska Vetenskaps Akademiens Handlingar, 1827, p. 85-155, pls. 1-6.

Dresser, Hugh, 1954, Notes on some brachiopods from the Itaituba Formation (Pennsylvanian) of the Tapajós River, Brazil: Bulletins of American Paleontology, v. 35, no. 149, p. 15-68, 8 pls. 
Dunbar, C. O., and Condra, G. E., 1932, Brachiopoda of the Pennsylvanian System in Nebraska: Nebraska Geological Survey, 2d ser., Bulletin 5, $377 \mathrm{p.}, 44 \mathrm{pls}$.

Fenton, C. L., 1928, Forms of Strophomena from Black River and Richmond Formations: American Midland Naturalist, v. 11, nos. 3-4, p. 144-159, pls. 8-10.

Foerste, A. F., 1910, Preliminary notes on Cincinnatian and Lexington fossils of Ohio, Indiana, Kentucky, and Tennessee: Denison University Scientific Laboratories Bulletin, v. 16, p. 17-100, 6 pls.

1924, Upper Ordovician faunas of Ontario and Quebec: Canada Geological Survey Memoir 138, 255 p., 46 pls.

Hall, James, and Clarke, J. M., 1892, An introduction to the study of the genera of Paleozoic Brachiopoda: New York Geological Survey, Paleontology, v. 8, pt. 1, 367 p., 20 pls. [1893].

Havlícek, Vladimír, 1967, Brachiopoda of the suborder Strophomenidina in Czechoslovakia: Czechoslovakia Ústrední Ústav Geologicky Rozpravy, v. 33, 235 p., 52 pls.

Jaanusson, Valdar, 1971, Evolution of the brachiopod hinge: Smithsonian Contributions to Paleobiology, No. 3, p. 33-46, 2 pls., 6 figs.

Kelly, F. B., 1967, Silurian leptaenids (Brachiopoda): Palaeontology, v. 10 , pt. 4 , p. $590-602$, pl. 8-9.

King, William, 1846, Remarks on certain genera belonging to the Class Palliobranchiata: Annals and Magazine of Natural History, v. 18, p. 26-42, 83-94.

Miller, S. A., 1897, Strophomena and the type of the genus: Natural Science Journal [New Bedford, Mass.], v. 1, no. 2, p. 29-35.

Neuman, R. B., 1967, Some silicified Middle Ordovician brachiopods from Kentucky: U.S. Geological Survey Professional Paper 583-A, p. A1-A14, 2 pls.

Nickles, J. M., 1903, The Richmond Group in Ohio and Indiana and its subdivisions, with a note on the genus Strophomena and its type: American Geologist, v. 32, p. 202-218.

Parsley, R. L., 1981, Echinoderms from Middle and Upper Ordovician rocks of Kentucky: U.S. Geological Survey Professional Paper 1066-K, 9 p.

Pojeta, John, Jr., 1979, The Ordovician paleontology of Kentucky and nearby States-Introduction: U.S. Geological Survey Professional Paper 1066-A, 48 p.
Pope, J. K., 1976, Comparative morphology and shell histology of the Ordovician Strophomenacea (Brachiopoda): Palaeontographica Americana, v. 8, no. 49 , p. 129-213, 31 figs.

Richards, R. P., and Bambach, R. K., 1975, Population dynamics of some Paleozoic brachiopods and their paleoecological significance: Journal of Paleontology, v. 49, no. 5, p. 775-798, 19 figs.

Salmon, E. S., 1942, Mohawkian Rafinesquinae: Journal of Paleontology, v. 16 , no. 5 , p. $564-603$, pls. $85-87$, 8 figs.; correction, v. 17 , no. 3, p. $309,1943$.

Spjeldnaes, Nils, 1957, The Middle Ordovician of the Oslo Region, Norway; 8. Brachiopods of the Suborder Strophomenida: Norsk Geologisk Tidsskrift, v. 37, no. 1, p. 1-214, 14 pls.

Twenhofel, W. H., 1927, Geology of Anticosti Island: Canada Geological Survey Memoir 154, 481 p., 160 pls.

Walker, K. R., and Parker, W. C., 1976, Population structure of a pioneer and a later stage species in an Ordovician ecological succession: Paleobiology, v. 2, no. 3, p. 191-201, 8 figs.

Wang, Yü, 1949, Maquoketa Brachiopoda of Iowa: Geological Society of America Memoir 42, 55 p., 12 pls.

Williams, Alwyn, 1962, The Barr and lower Ardmillan series (Caradoc) of the Girvan district, south-west Ayrshire, with descriptions of the Brachiopoda: Geological Society of London Memoir 3, $267 \mathrm{p}$., $25 \mathrm{pls}$.

1963, The Caradocian brachiopod faunas of the Bala district, Merionethshire: British Museum (Natural History) Bulletin, Geology, v. 8, no. 7, p. 327-471, 16 pls.

1965, Suborder Strophomenidina, in Williams, Alwyn, and others, 1965, Brachiopoda, pt. H of Moore, R. C., ed., Treatise on invertebrate paleontology: New York and Lawrence, Kans., Geological Society of America and University of Kansas Press, v. 1, p. H362-H412.

Winchell, N. H., 1881, New Brachiopoda from the Trenton and Hudson River Formations in Minnesota: Minnesota Geological and Natural History Survey, Annual Report 9 for 1880, p. 115-124.

Winchell, N. H., and Schuchert, Charles, 1892, Preliminary descriptions of new Brachiopoda from the Trenton and Hudson River Groups of Minnesota: American Geologist, v. 9, p. 284-294.

1895. The Lower Silurian Brachiopoda of Minnesota: Minnesota Geological and Natural History Survey, Final Report, v. 3, pt. 1, p. 333-474, pls. 29-34. 


\section{PLATES 1-8}

Ccntact photographs of the plates in this report are available, at cost, from the U.S. Geological Survey Library, Federal Center, Denver, CO 80225. 


\section{PLATE 1}

FIGURES 1-14. Oepikina minnesotensis (Winchell) (p. L6). Exterior of ventral valves. Figs. 1, 3-5 from USGS loc. 7875-CO; figs. 2, 6-14 from USGS loc. 5078-CO.

1. Highly inflated specimen. $a$, Stereophotographs, $\times 1 . b, \times 2 . c$, Profile, $\times 2$. USNM 245277 .

2. Specimen with normal outline and profile, and strongly alternate costellae. Ornament magnified on pl. 2 , fig. 12. $a$, Stereophotographs, $\times 1 . b, \times 2$. USNM 245291 .

3. Elongated specimen. $a, \times 1 . b, \times 2$. USNM 245278 .

4. Highly inflated specimen. $a, \times 1 . b, \times 2 . c$, Profile, $\times 2$. USNM 245279.

5. Specimen with moderate curvature. $a$, Stereophotographs, $\times 1 . b, \times 2 . c$, Profile, $\times 2$. USNM 245280 .

6. Slightly nasute specimen. $a$, Stereophotographs, $\times 1 . b, \times 2$. USNM 245292 .

7. Specimen with low profile and sharp uniform costellae. Ornament magnified on pl. 2, fig. 11. $a, \times 1 . b, \times 2$. USNM 245293 .

8. Sharply geniculate specimen. $a, \times 1 . b, \times 2$. USNM 245294 .

9. Transverse, sharply geniculate specimen with angular cardinal extremities. $a, \times 1 . b, \times 2$. USNM 245295.

10. Rugose specimen, $\times 2$. USNM 245296 .

11. Flat specimen with growth interruption and injury. $a, \times 1 . b, \times 2$. USNM 245297.

12. Flat specimen with growth interruption. $a, \times 1 . b, \times 2$. USNM 245298 .

13. Nasute specimen, $\times 1$. USNM 245299 .

14. Small flat specimen. $a, \times 1 . b, \times 2$. USNM 245300 . 


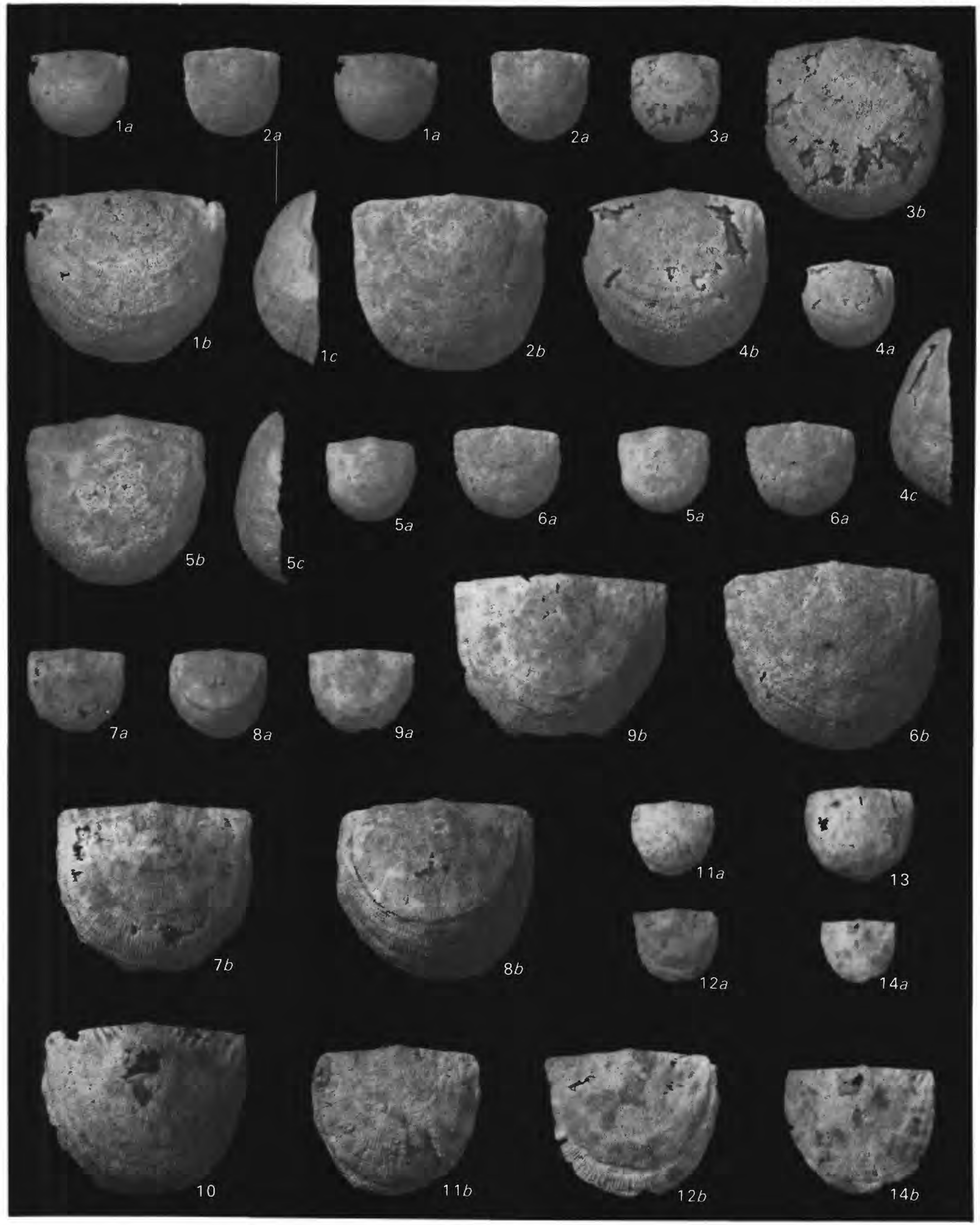




\section{PLATE 2}

FIGURES 1-12. Oepikina minnesotensis (Winchell) (p. L6). Interior of ventral valves and ornament. Figs. 1-4, 7-12 from USGS loc. 5078-CO; figs. 5-6 from USGS loc. 7875-CO.

1. Large, highly inflated specimen. $a$, Stereophotographs, $\times 1 . b, \times 2 . c$, Ventral structures, $\times 4 . d$, Grooved tooth with semidenticles, pedicle callist, $\times 6$. USNM 245301 .

2. Specimen with normal convexity. $a$, Stereophotographs, $\times 1 . b, \times 2$. USNM 245302.

3. Specimen with low convexity. $a, \times 1 . b, \times 2$. USNM 245303.

4. Abraded specimen with moderate convexity. Hole in beak is caused by lack of preservation of pseudodeltidium. $a, \times 2$. $b$, Grooved teeth and pedicle callist, $\times 4$. $c$, Stereophotographs, $\times 1$. USNM 245304.

5. Highly inflated, transverse specimens, $\times 2$. USNM 245281.

6. Highly inflated specimen, $\times 2$. USNM 245282 .

7. Small specimen. $a, \times 1 . b, \times 2$. USNM 245305 .

8. Small subtriangular specimen. $a, \times 1 . b, \times 2$. USNM 245306 .

9. Specimen with low convexity. $a, \times 1 . b, \times 2$. USNM 245307.

10. Ornament, dorsal valve. Specimen shown on pl. 3, fig. 19. $\times$ 4. USNM 245308 .

11. Ornament, ventral valve. Specimen shown on pl. 1, fig. 7. $\times 4$. USNM 245293.

12. Ornament, ventral valve. Specimen shown on pl. 1, fig. $2 . \times 4$. USNM 245291 . 


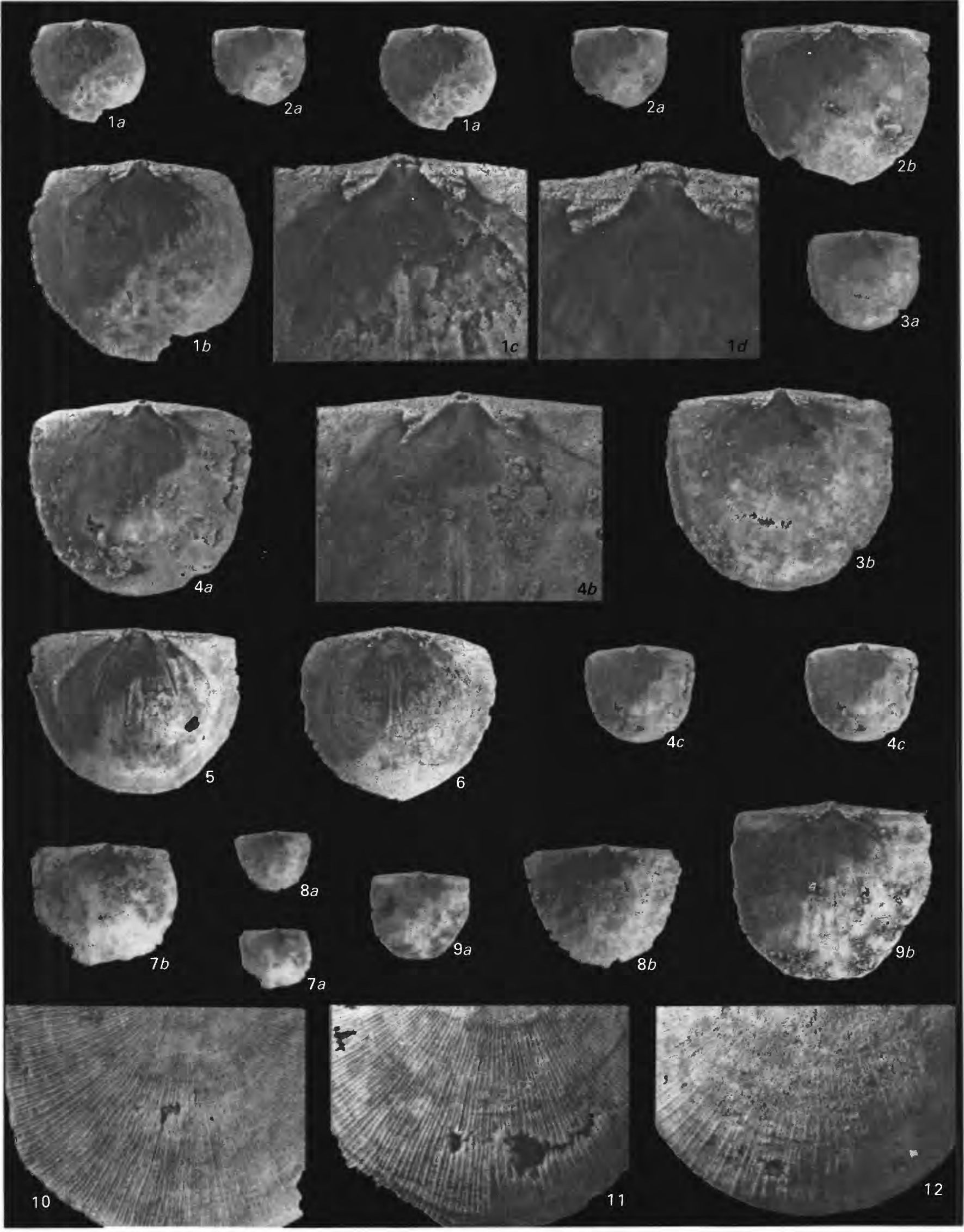




\section{PLATE 3}

FIGUREs 1-19. Oepikina minnesotensis (Winchell) (p. L6). Interior and exterior of dorsal valves. Figs. 1-8 from USGS loc. 7875-CO; figs. 9-19 from USGS loc. 5078-CO.

1. Subcircular specimen, $\times 2$. USNM 245283.

2. Large specimen with inclined cardinal process lobes, $\times 2$. USNM 245284 .

3. Transverse specimen with deep round adductor muscle scars and short transmuscle ridges, $\times 2$. USNM 245285 .

4. Flat specimen, $\times 2$. USNM 245286 .

5. Large specimen without prominent marginal rim, $\times 2$. USNM 245287.

6. Deformed subrectangular specimen, $\times 2$. USNM 245288.

7. Subtriangular specimen, $\times 2$. USNM 245289.

8. Specimen with prominent transmuscle ridges, $\times 2$. USNM 245290.

9. Specimen with well-defined cardinalia. $a$, Stereophotographs, $\times 2 . b$, Specimen inclined to show cardinalia. Note semidenticles in sockets and lack of silicification of core of cardinal process lobes, $\times 4$. USNM 245309.

10. Young transverse specimen with weakly defined transmuscle ridges, $\times 2$. USNM 245310.

11. Large specimen with circular marginal rim, $\times 2$. USNM 245311.

12. Small flat deformed specimen. Note pronounced posterior-lateral transmuscle ridges and long socket buttress ridges, $\times 2$. USNM 245312.

13. Specimen with well-defined cardinalia. $a, \times 2 . b$, Inclined view, $\times 4$. USNM 245313.

14. Small flat specimen showing the early development of the posterior-lateral transmuscle ridges, $\times 2$. USNM 245314 .

15. Small flat specimen with radial wrinkles, $\times 2$. USNM 245315 .

16. Subtriangular specimen, incomplete. $a, \times 2 . b$, Inclined view; note semidenticles in sockets, $\times 4$. USNM 245316 .

17. Dorsal exterior, stereophotographs, $\times 2$. USNM 245317 .

18. Dorsal exterior with slight rugation along hingeline, $\times 2$. USNM 245318.

19. Dorsal exterior. Magnified view shown on pl. 2, fig. 10. $\times 2$. USNM 245308. 

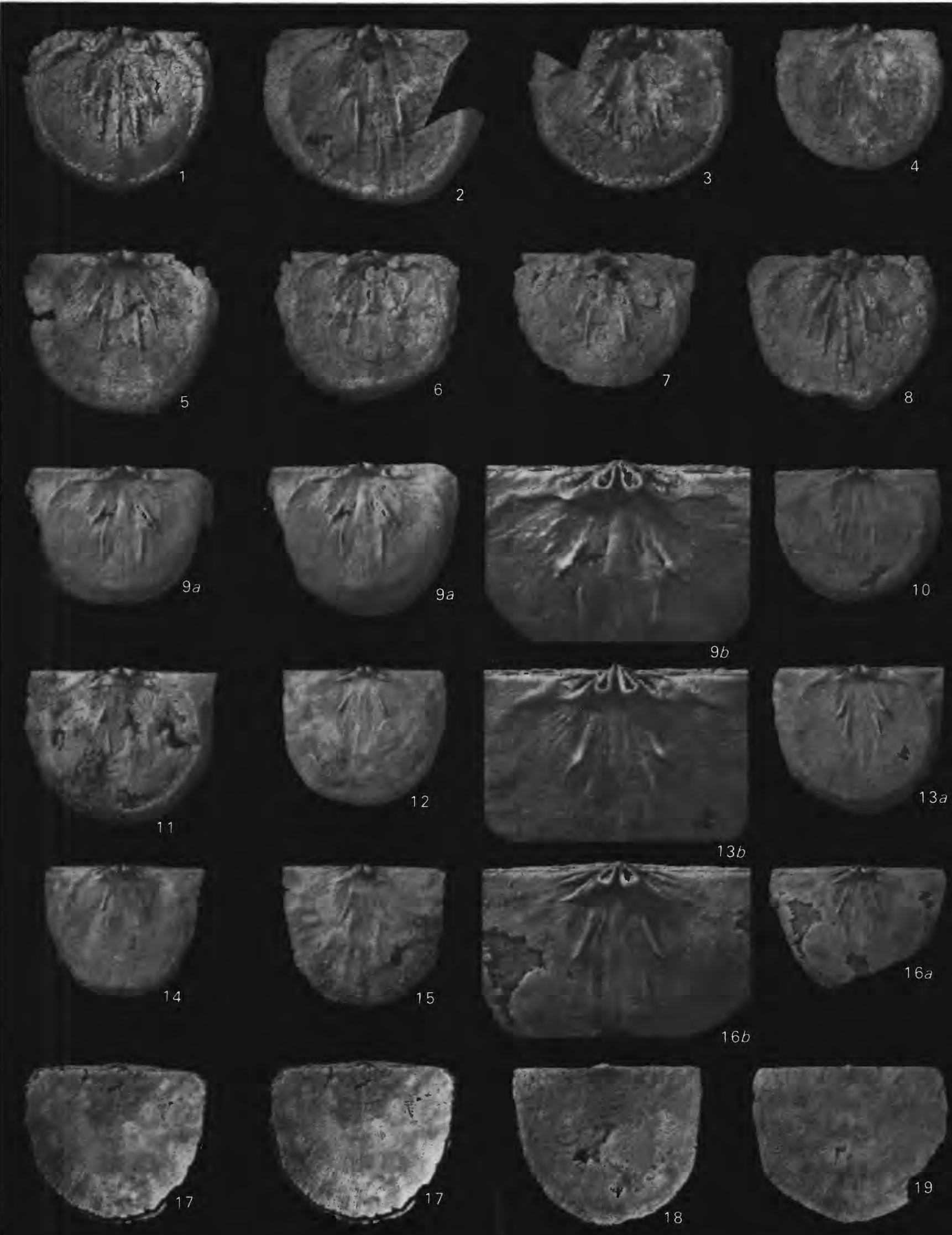


\section{PLATE 4}

FIGURE 1. Tetraphalerella sp. (p. L20). Stereophotographs, exterior and interior of highly inflated dorsal valve. USGS loc. 5078-CO. $a-b, \times 2$. USNM 245319.

FIguREs 2-6. Tetraphalerella cf. T. costellata (Cooper) (p. L22). USGS loc. 5078-CO.

2. Posterior region of a large, incomplete ventral valve. $a-d, \times 3$. USNM 245320.

3. Complete specimen. $a, \times 1$. $b$, Stereophotographs, dorsal valve, $\times 2 . c$, Stereophotographs, ventral valve, $\times 2 . d$, Dorsal valve inclined to show growth interruption and ventral interarea, $\times 2$. USNM 245321.

4. Exterior and interior of ventral valve. $a, \times 1 . b$, Stereophotographs, exterior, $\times 2$. c, Stereophotographs, interior, $\times 2 . d-e$, Two views of posterior region, $\times 3 . f$, Ornament, $\times 6$. USNM 245322.

5. Incomplete dorsal valve. $a$, Stereophotographs, $\times 2 . b$, Interior, $\times 2 . c$, Ornament, $\times 6$. USNM 245323.

6. Exterior and interior of juvenile ventral valve. $a-b, \times 3$. USNM 245324 . 

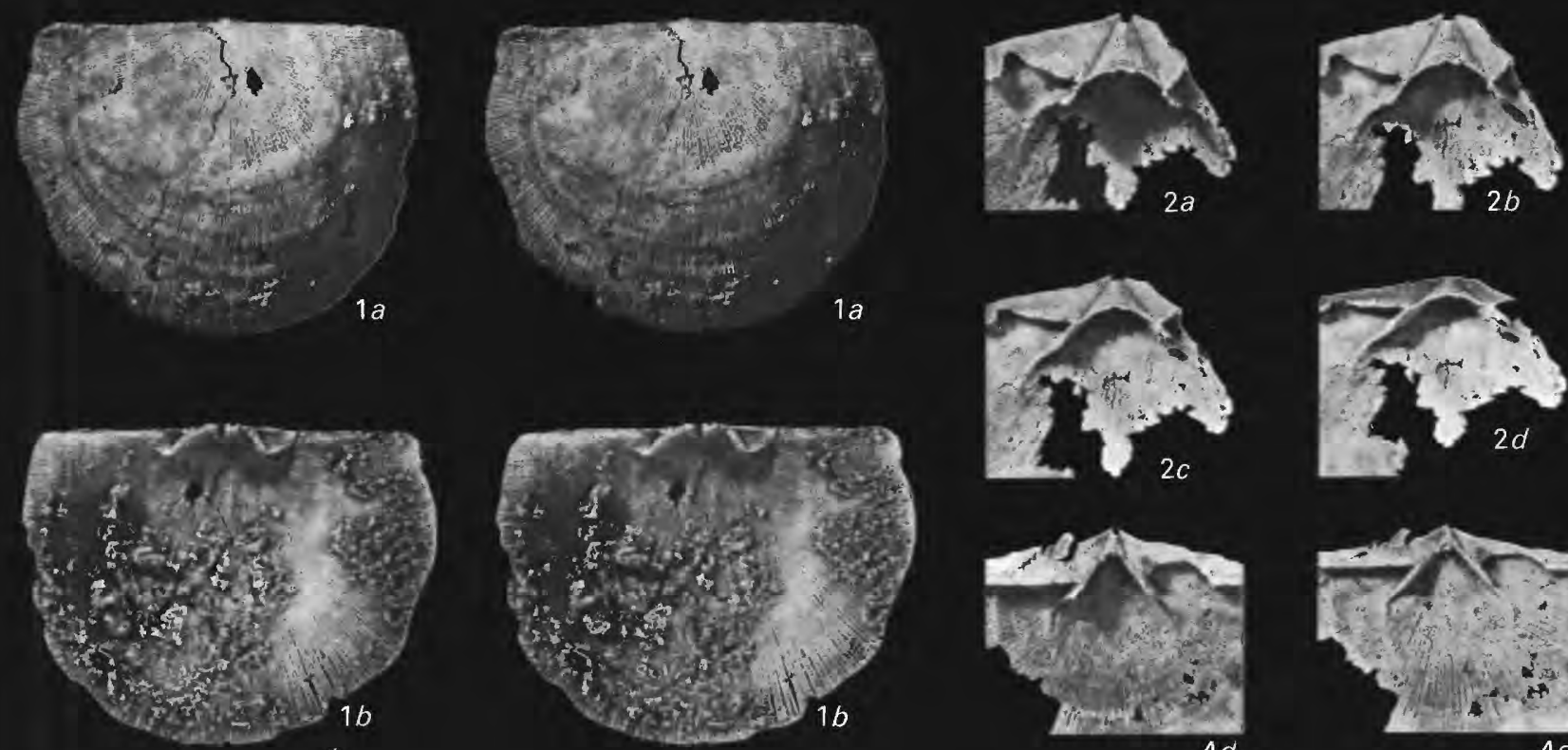

$1 a$
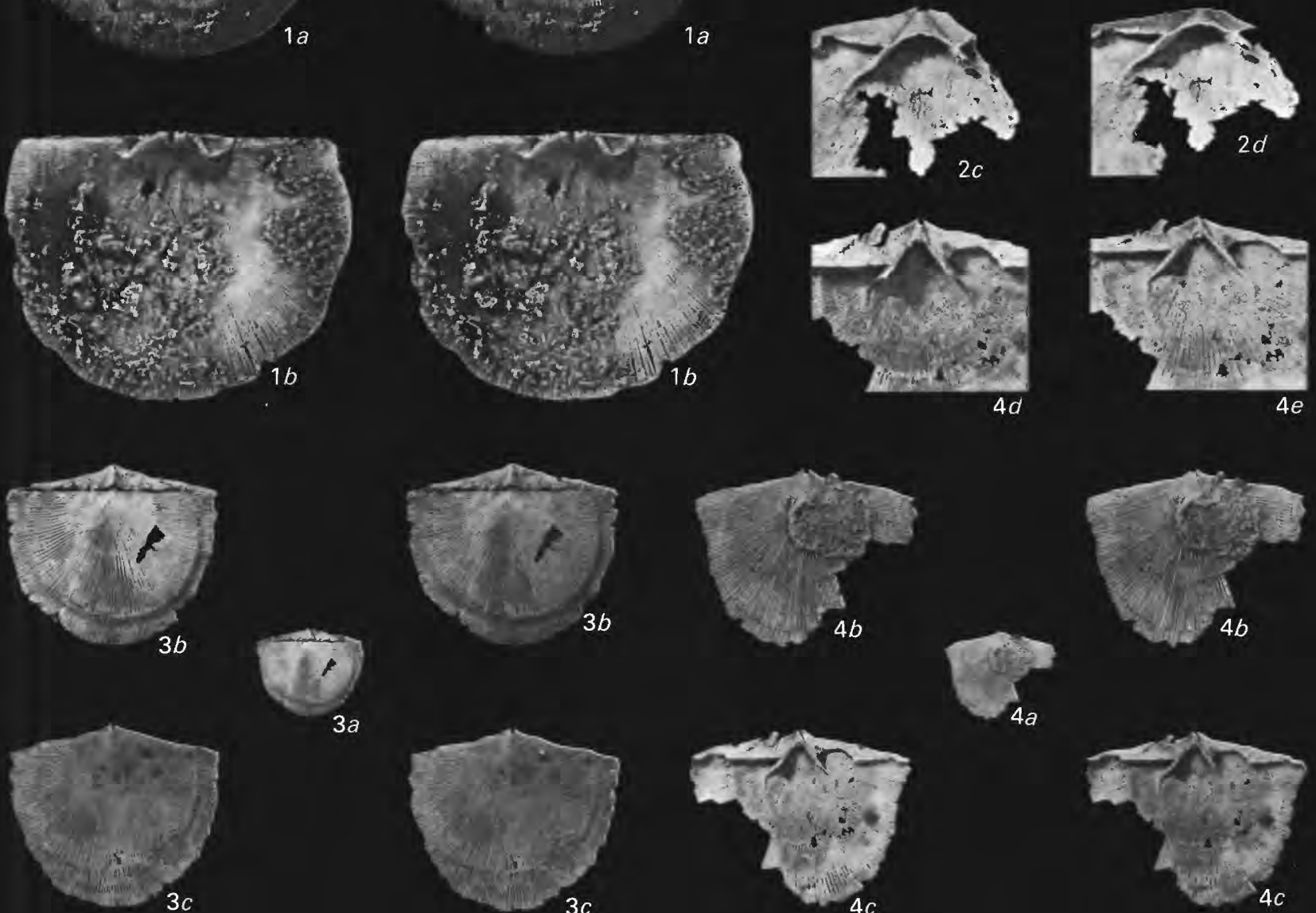

$3 a$
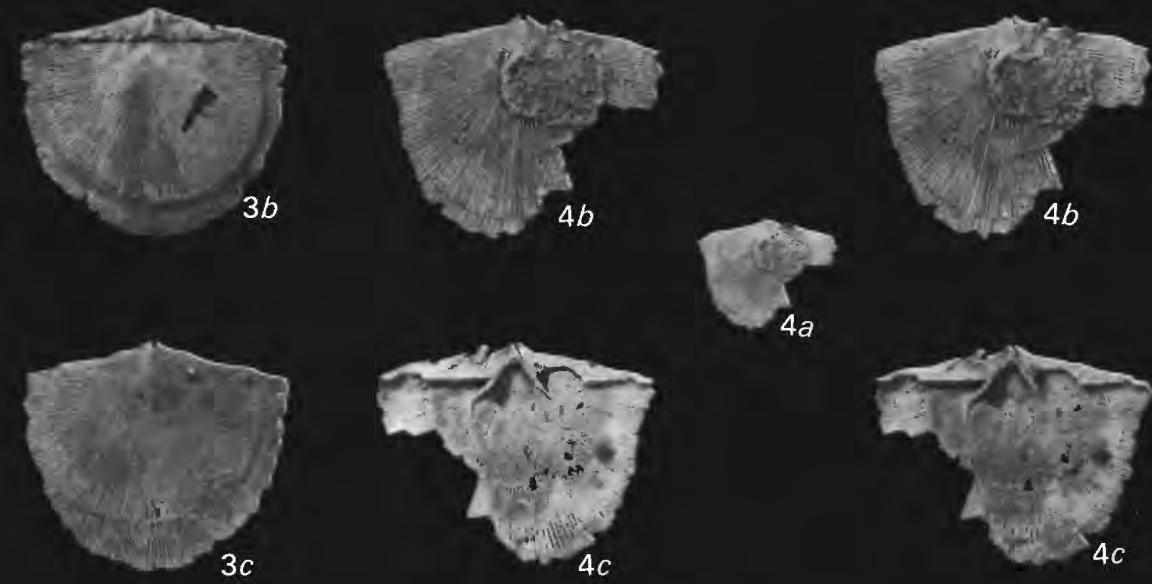

$a$

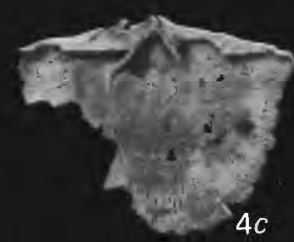

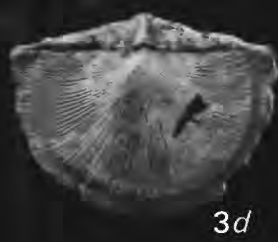
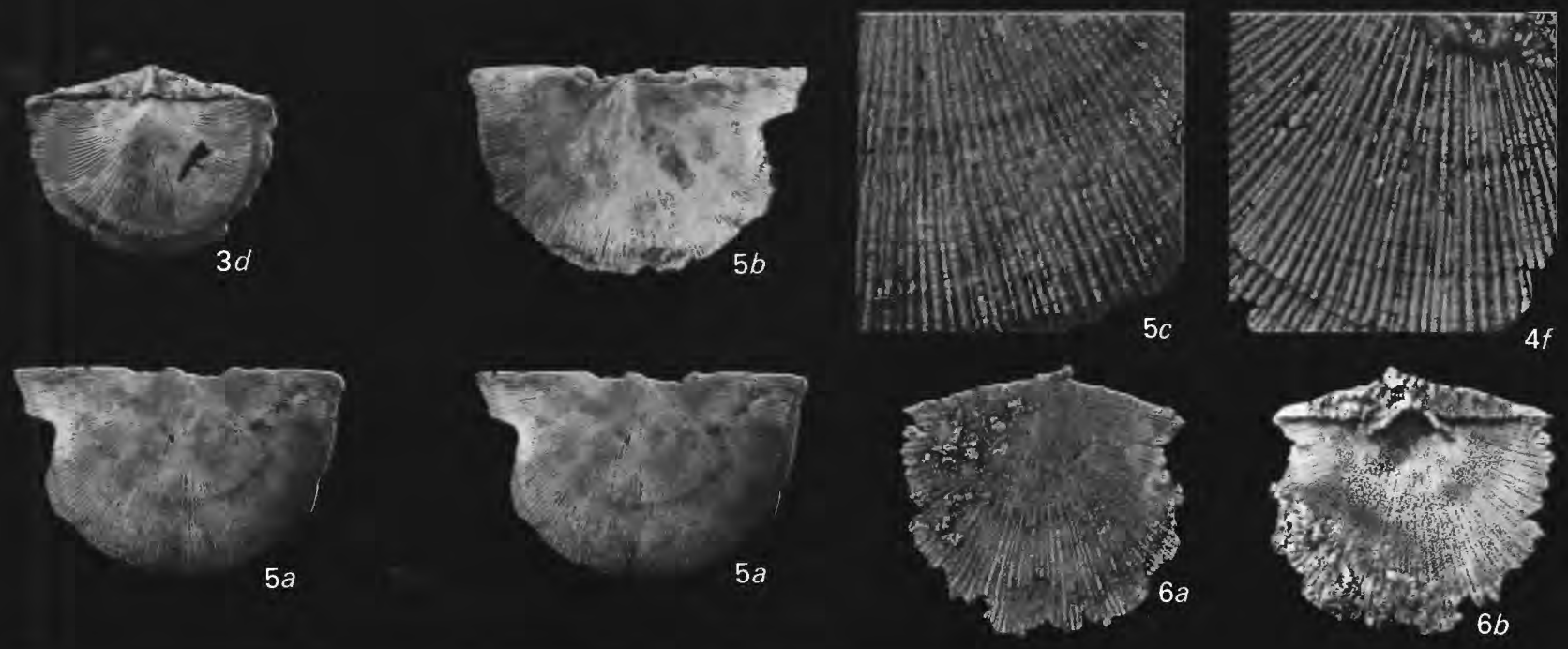


\section{PLATE 5}

FigURES 1-6. Furcitella cf. F. scofieldi (Winchell and Schuchert) (p. L19). USGS loc. 5078-CO.

1. Large incomplete dorsal valve. $a-b$, Stereophotographs, exterior, interior, $\times 2 . c-e$, Cardinalia, $\times 3$. USNM 245327.

2. Small incomplete dorsal valve. $a-b$, Stereophotographs, $\times 2 . c-d$, Cardinalia, $\times 3$. e, Ornament, $\times 5$. USNM 245328.

3. Small complete specimen. Note faint dorsal fold. $a, \times 1 . b$, Rotated to show ornament, fold, and interarea, $\times 3 . c-d$, Stereophotographs, dorsal valve, ventral valve, $\times 2$. USNM 245329.

4. Poorly preserved dorsal valve. $a-b$, Stereophotographs, exterior, interior, $\times 2$. USNM 245330 .

5. Small dorsal valve. $a$, Exterior, $\times 2 . b$, Interior, $\times 2 . c$, Ornament, $\times 5$. USNM 245331.

6. Small, poorly preserved dorsal valve. $a$, Exterior, $\times 2$. $b$, Interior, $\times 2$. USNM 245332.

FIGURE 7. Murinella? sp. (p. L26). Poorly preserved dorsal valve. USGS loc. 7875-CO. $a$, Stereophotographs, interior, $\times 2 . b$, Exterior, $\times 2$. USNM 245337. 

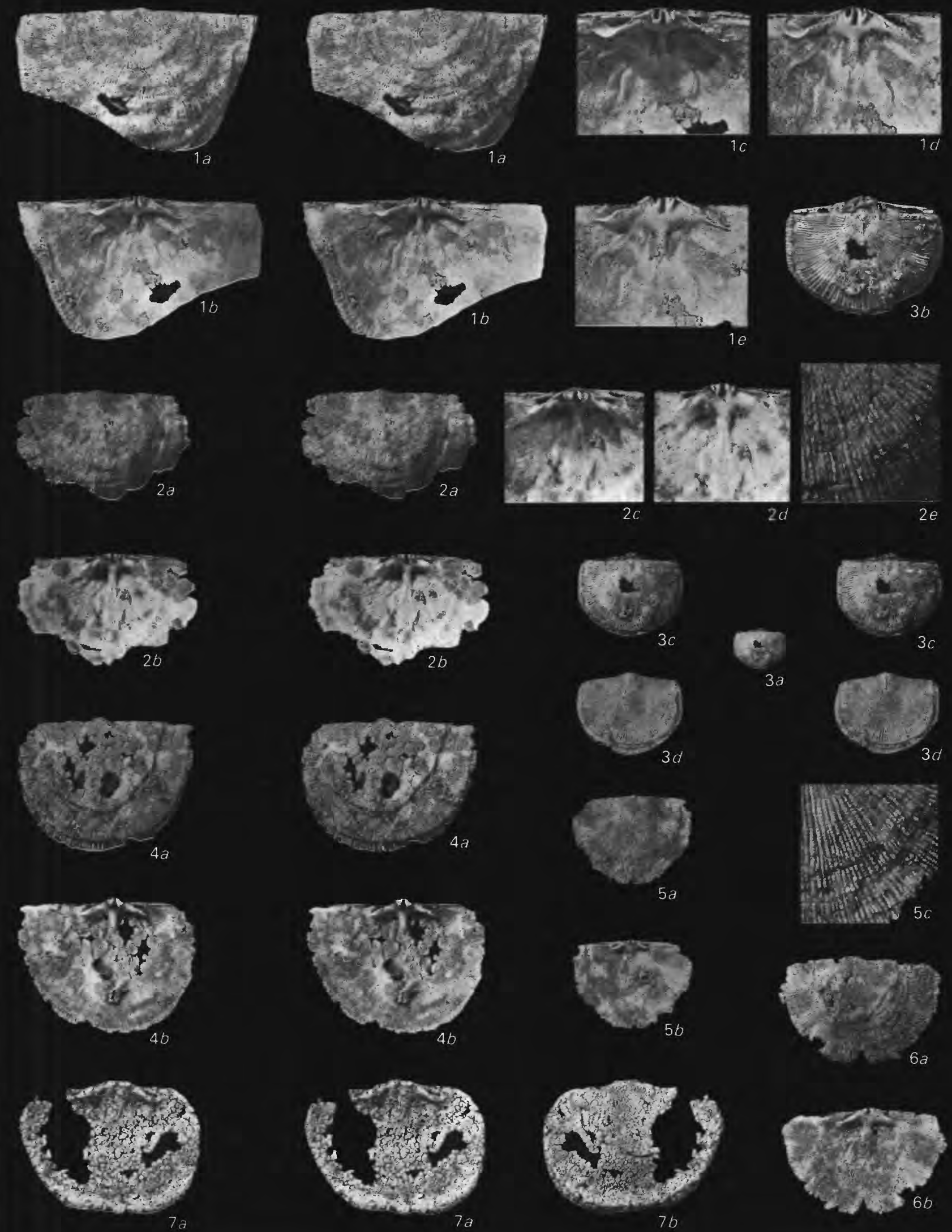


\section{PLATE 6}

FIGURES 1-2. Tetraphalerella cf. T. costellata (Cooper) (p. L22). USGS loc. 5078-CO.

1. Large ventral valve. $a-b$, Stereophotographs, exterior, interior, $\times 2 . c$, Posterior region, $\times 3 . d$, Ornament, $\times 6$. USNM 245325.

2. Small ventral valve. $a-b$, Exterior, interior, $\times 2$. USNM 245326.

FIGURES 3-6. Furcitella ef. F. scofieldi (Winchell and Schuchert) (p. L19). USGS loc. 5078-CO.

3. Large ventral valve with faint sulcus and marginal plicae. $a-b$, Stereophotographs, exterior, interior, $\times 2$. $c$, Posterior region inclined, $\times 3 . d$, Ornament, $\times 5$. USNM 245333 .

4. Small ventral valve. $a-b$, Exterior, interior, $\times 2$. USNM 245334.

5. Ventral valve. $a, \times 1 . b-c$, Stereophotographs, exterior, interior, $\times 2 . d-e$, Posterior region, $\times 3$. USNM 245335 .

6. Ventral valve with coma. $a-b$, Stereophotographs, exterior, interior, $\times 2 . c$, Ornament, $\times 5$. USNM 245336 . 


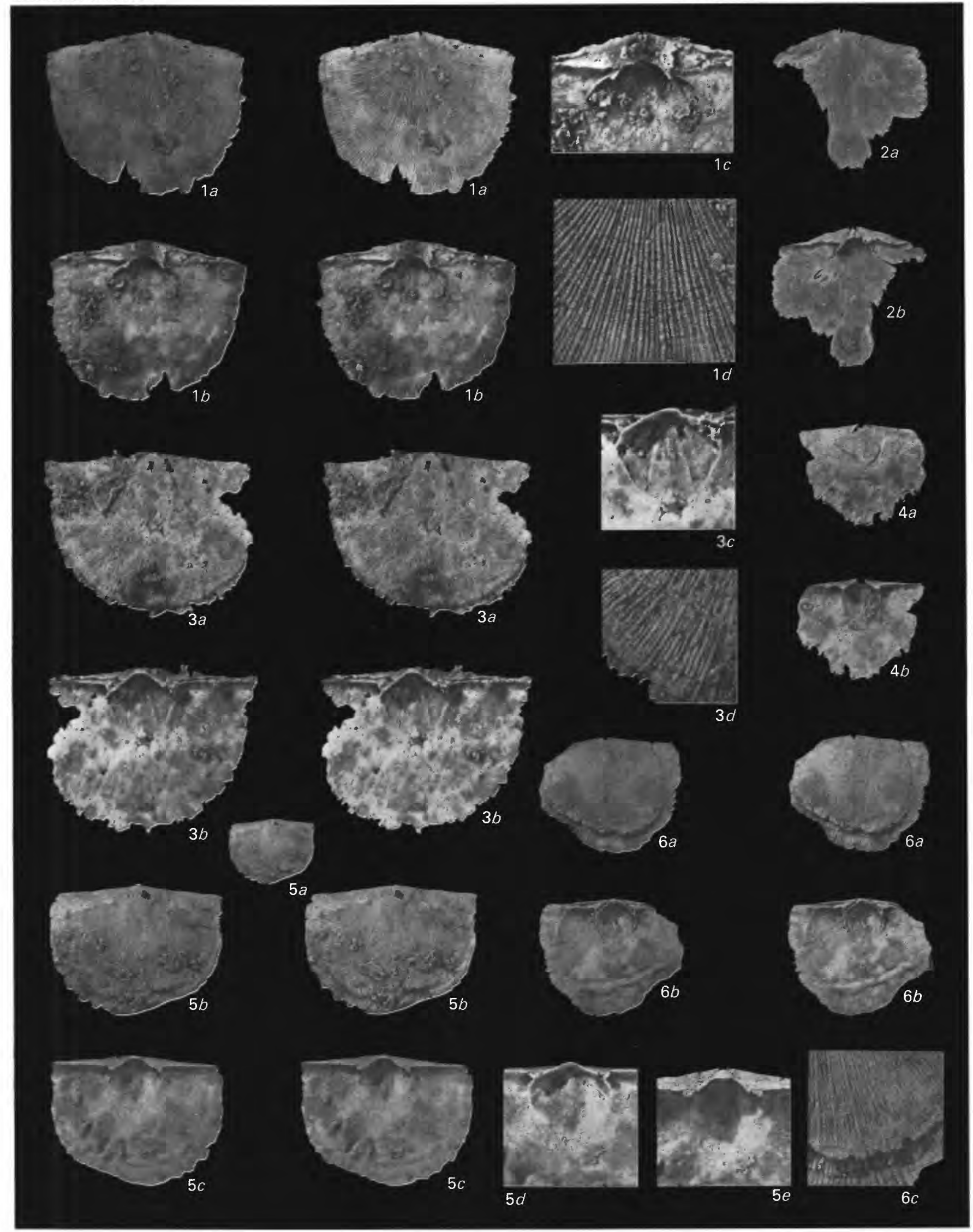




\section{PLATE 7}

FigurES 1-9. Tetraphalerella cf. T. musculosa (Fenton) (p. L23). USGS loc. 7784-CO.

1. Large dorsal valve, center exfoliated. Note wrinkle in left cardinal extremity, $\times 1$. USNM 245338.

2. Exterior of poorly preserved, large ventral valve, $\times 1$. USNM 245339.

3 . Interior, ventral valve, $\times 1$. USNM 245340 .

4. Teeth, pseudodeltidium, and muscle scar of large incomplete ventral valve, $\times 2$. USNM 245341.

5. Small ventral valve, $\times 1 \frac{112}{2}$. USNM 245342 .

6. Small ventral valve, $\times 1 \frac{11}{2}$. USNM 245343 .

7. Interior, incomplete ventral valve, $\times 1$. USNM 245344 .

8. Interior, small transverse dorsal valve. $a$, Interior filled with debris, $\times 1$. $b$, Cardinal process lobes, $\times 2$. USNM 245345 .

9. Small, complete, poorly preserved specimen with transverse outline. $a, \times 1 . b$, Inclined to show pseudodeltidium, $\times 1 \frac{1}{2}$. USNM 245346.

Figures 10-13. Holtedahlina sulcata (de Verneuil) (p. L20). Introduced for comparison to Furcitella cf. $F$. scofieldi (Winchell and Schuchert) (pl. 5, figs. 1-6, and pl. 6, figs. 3-6).

10. Immature dorsal valve. Note cleft medial ridge and sharp posterior-lateral transmuscle ridges, $\times 2$. Whitewater Formation, Morning Sun, Preble County, Ohio. MU-220T.

11. Interior, large dorsal valve, $\times 2$. Whitewater Formation, McDill's Mill, on Four Mile Creek in Preble County, 9 mi. north of Oxford, Ohio. MU-221T.

12. Interior of dorsal valve, $\times 2$. Whitewater Formation, Beasley's Creek, north of Camden, Preble County, Ohio. MU-222T.

13. Interior of small ventral valve, $\times 2$. Whitewater Formation, near Oxford, Butler County, Ohio. MU-223T.

Figures 14-15. Coolinia subplana (Conrad) (p. L27, L28). Introduced for comparison to Pionomena recens Neuman (figs. 16-31). Note medial node.

14. Cardinalia, large specimen, left brachiophore broken, $\times 2$. Waldron Shale, Hartsville, Bartholomew County, Ind. MU-224T.

15. Cardinalia, left brachiophore broken, $\times 2$. Waldron Shale, Sandusky, Decatur County, Ind. MU-225T.

Figures 16-31. Pionomena recens Neuman (p. L27). Figs. 16-27, 31, from USGS loc. 5015-CO: figs. 28-30 from USGS loc. $4880-C O$.

16. Interior, large dorsal valve, $\times 2 \frac{1}{2}$. USNM 245347 .

17. Interior, small ventral valve, $\times 2 \frac{1}{2}$. USNM 245348 .

18. Exterior, small ventral valve, $\times 2 \frac{1}{2}$. USNM 245349 .

19. Interior, dorsal valve, $\times 2^{1 / 1}$. USNM 245350 .

20. Interior, ventral valve. $a, \times 2 \frac{1}{2} . b$, S.E.M. photograph of right interarea and pseudodeltidium, showing perideltidium, $\times$ about 12. $c$, Interarea, teeth, and pseudodeltidium, $\times 4$. USNM 245351.

21. Interior ventral valve. $a, \times 2 \frac{1}{2}$. $b$, Pseudodeltidium and interarea with perideltidia, $\times 4$. USNM 245352 .

22. Interior ventral valve. $a, \times 2 \frac{1}{2}$. $b$, Interarea, pseudodeltidium, and perideltidia, $\times 4$. USNM 245353 .

23. Interior dorsal valve, $\times 2 \frac{1}{2}$. USNM 245354 .

24. Interior dorsal valve. $a, \times 2 \frac{1}{2} . b$, Cardinalia, note medial spine, $\times 4$. USNM 245355.

25. Exterior dorsal valve, $\times 2 \frac{1}{2}$. USNM 245356 .

26. Exterior dorsal valve. $a, \times 2 \frac{1}{2}$. $b$, Interarea, chilidium, and pseudodeltidium, $\times 4$. USNM 245357 .

27. Interior dorsal valve, $\times 2 \frac{1}{2}$. USNM 245358 .

28. Interior dorsal valve. $a, \times 2 \frac{1}{2} . b$, Cardinalia and medial node, $\times 4$. USNM 245360 .

29. Interior dorsal valve. $a, \times 2 \frac{1}{2} . b$, Cardinalia and medial node, $\times 4$. USNM 245361 .

30. Cardinalia, $\times 4$. USNM 245362.

31. Cardinalia and medial node, $\times 4$. USNM 245359. 

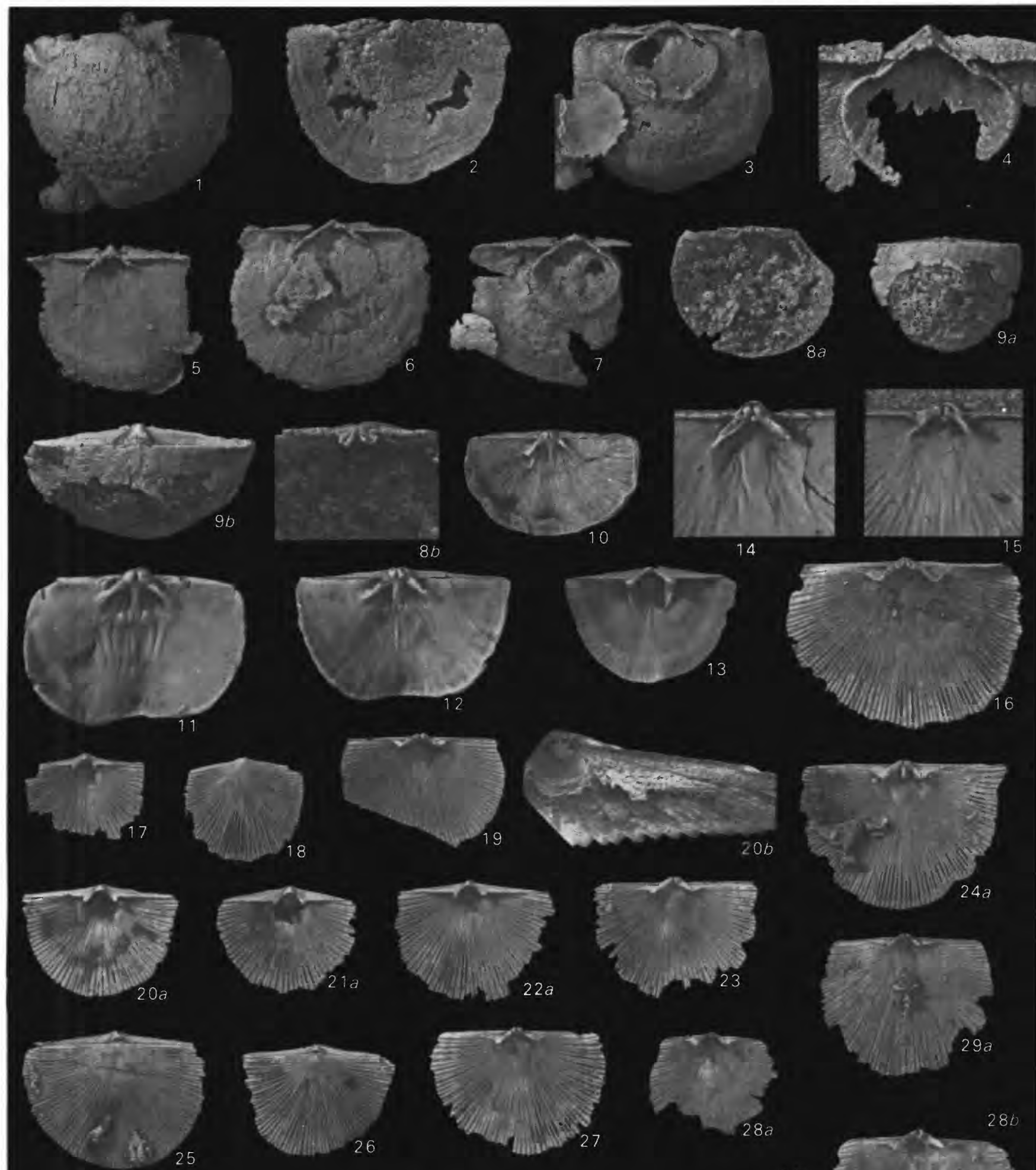

$24 b$
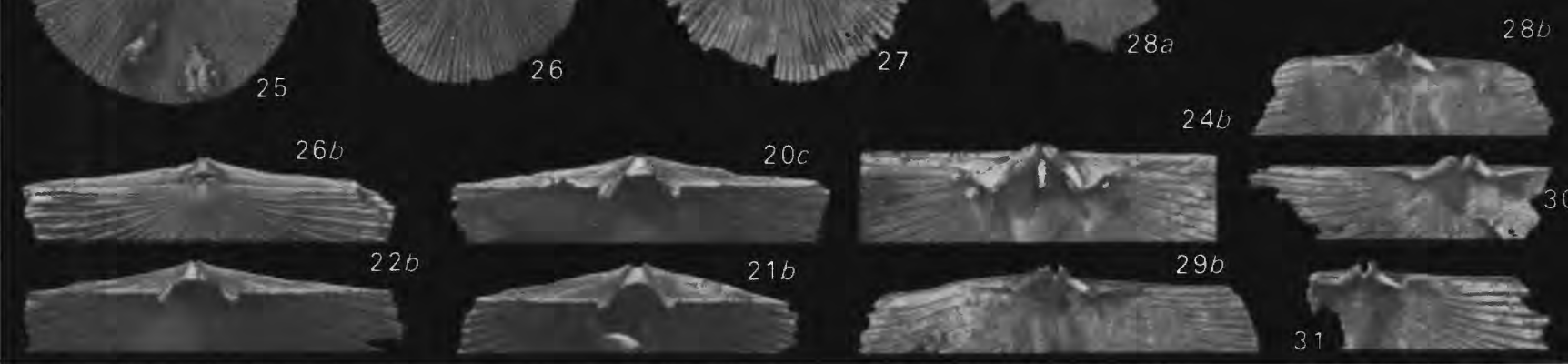


\section{PLATE 8}

Figures 1-5. Leptaena kentuckiana n. sp. (p. L24). USGS loc. 5136-CO.

1. Paratype, juvenile ventral valve. $a$, Exterior, $\times 1 . b-c$, Stereophotographs, exterior, interior, $\times 3 . d-e$, Delthyrial chamber, interarea, and teeth, $\times 4$. USNM 245363.

2. Paratype, juvenile ventral valve. $a-b$, Exterior, interior, $\times 3 . c-d$, Pseudodeltidium, delthyrial chamber, and teeth, $\times 4$. USNM 245364.

3. Paratype, juvenile dorsal valve. $a, \times 1 . b-c$, Stereophotographs, exterior, interior, $\times 3 . d-e$, Cardinalia, cardinal process, chilidium, sockets, and endospines, $\times 4$. USNM 245365.

4. Holotype, adult ventral valve. $a-b$, Stereophotographs, exterior, interior, $\times 1 \frac{112 .}{c}$, Enlargement of umbonal region for comparison with figs. $1 b$ and $2 a, \times 3 . d-e$, Delthyrial chamber, muscle scars, and teeth, $\times 2$. USNM 245367.

5. Paratype, juvenile dorsal valve. $a-b$, Exterior, interior, $\times 3$. $c$, Cardinalia, $\times 4$. USNM 245366 

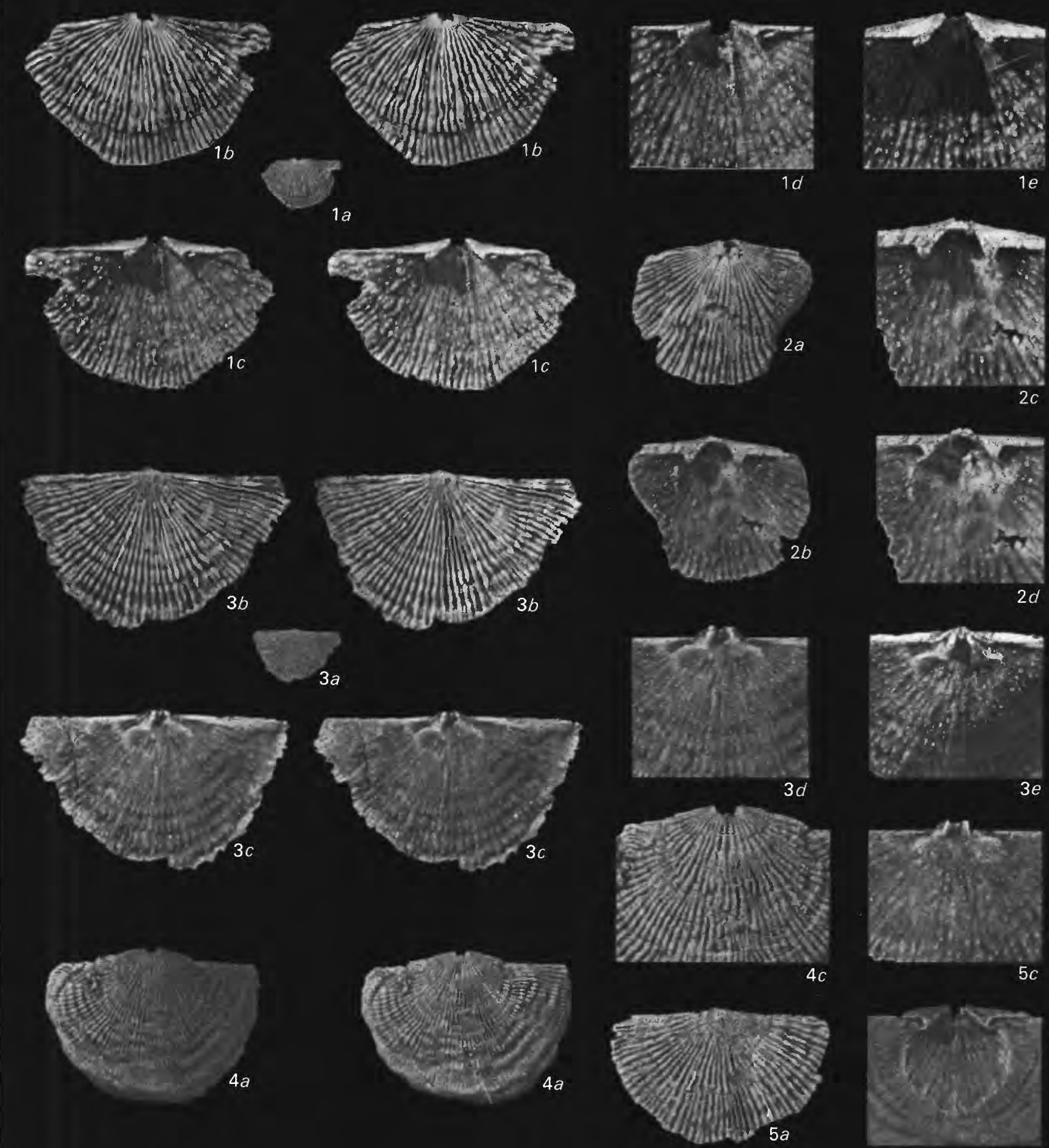

$4 c$

$5 c$
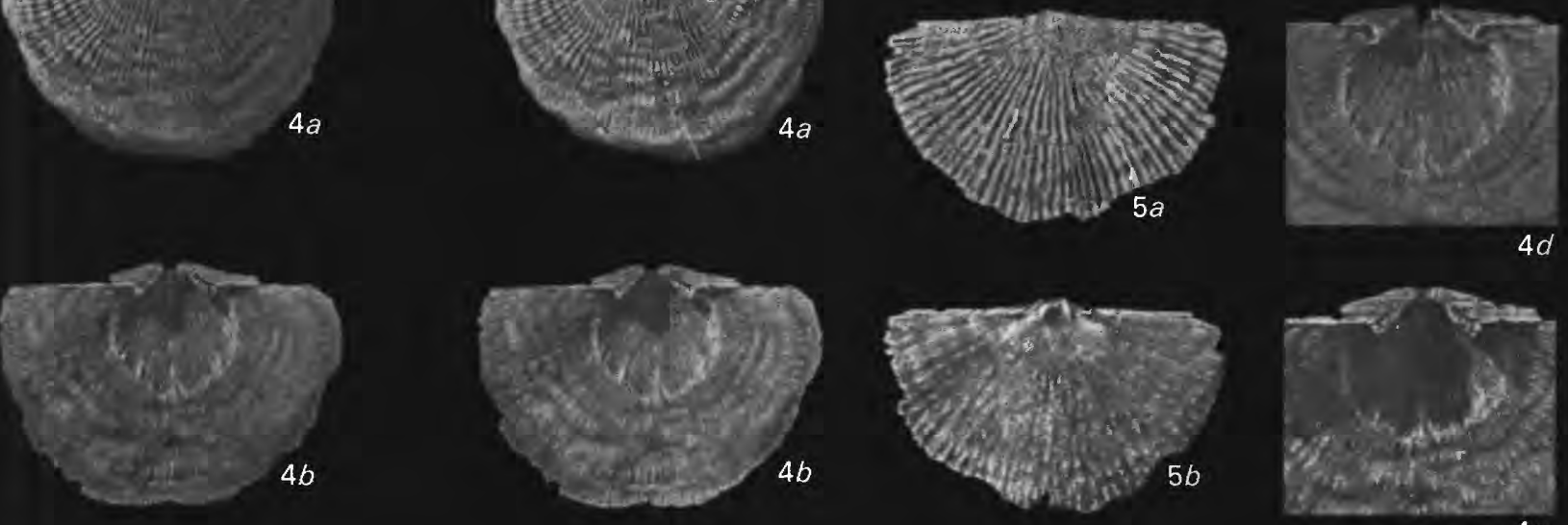
